Universidade de São Paulo

Instituto de Química

\title{
Estudo de Interfases Eletroquímicas Envolvendo Materiais Metálicos de Uso Odontológico
}

Jocicler Claudio Vieira

Dissertação de Mestrado

Orientadora:

Profa. Dra. Silvia Maria Leite Agostinho

São Paulo, 14 de fevereiro de 2006 
Este trabalho foi realizado sob a orientação da:

Profa. Dra. Silvia Maria Leite Agostinho 
À minha esposa Priscila e meu filho Lucas, pela resignação e amor em mim empenhados.

À minha mãe Benedita, pela dedicação e carinho.

Ao meu pai Vieira, pelo que de positivo influiu em minha personalidade.

Aos meus irmãos Jorge, Lu e Kako, pelo que aprendemos convivendo juntos nesta encarnação. A todos os meus amigos visíveis e invisíveis, por velarem por mim e por meus entes queridos. 


\section{Profundamente}

\begin{tabular}{|c|c|}
\hline Quando ontem adormeci & - Estavam todos dormindo \\
\hline Na noite de São João & Estavam todos deitados \\
\hline Havia alegria e rumor & Dormindo \\
\hline Estrondos de bombas luzes de Bengala & Profundamente. \\
\hline Vozes cantigas e risos & Quando eu tinha seis anos \\
\hline $\begin{array}{l}\text { Ao pé das fogueiras acesas. } \\
\text { No meio da noite despertei }\end{array}$ & $\begin{array}{l}\text { Não pude ver o fim da festa de São } \\
\text { João }\end{array}$ \\
\hline Não ouvi mais vozes nem risos & Porque adormeci \\
\hline Apenas balóes & $\begin{array}{l}\text { Hoje não ouço mais as vozes daquele } \\
\text { tempo }\end{array}$ \\
\hline Passavam errantes & Minha avó \\
\hline Silenciosamente & Meu avô \\
\hline Apenas de vez em quando & Totônio Rodrigues \\
\hline O ruído de um bonde & Tomásia \\
\hline Cortava o silêncio & Rosa \\
\hline Como um túnel. & Onde estão todos eles? \\
\hline Onde estavam os que há pouco & - Estão todos dormindo \\
\hline Dançavam & Estão todos deitados \\
\hline Cantavam & Dormindo \\
\hline E ric & Profundamente. \\
\hline
\end{tabular}

Manue1 Bandeira

No dia mais claro

Na noite mais densa

O mau sucumbirá

Ante a minha presença

Emblema dos Lanternas-Verdes, Quadrinhos
A cerejeira possui galhos firmes e imperturbáveis, os quais se quebram ante o peso da neve. Mais sábio é o salgueiro, que possui galhos flexíveis, os quais curvam-se quando a neve lhes faz peso, voltando - incólumes - ao estado anterior.

Baseado no pensamento que fez o médico japonês shirobei Akiama criar o Judô 


\section{Agradecimentos}

À professora doutora Silvia Maria Leite Agostinho, pela orientação, amizade e constantes demonstrações de humildade e ética profissional e pelo cabedal de conhecimentos de Química e de vida transmitidos com franco entusiasmo.

Ao Inada e ao Carlos, que compartilharam comigo da exultação e das idéias nos primórdios dos trabalhos experimentais, e das dificuldades, sucessos, frustrações, cisões e reatamentos que ocorreram no meio do caminho. No final, prevalece a cooperação, a amizade, o respeito e o aprendizado que cada um de nós, como ser único e insubstituível, promove pelo contato com seu semelhante.

À Mónica e à Célia, pela boa vontade em passar conhecimentos técnicos e pelo tempo dedicado em ensaios que auxiliaram na realização deste trabalho.

À Juliana, Gisele, Ruth, Lúcia, Isis, Nivalda, ao Douglas e ao Maico, pelo contato fraterno e prestimoso.

Ao Paulinho e ao Nivaldo, pelo grande auxílio prestado nas etapas de confecção de tantos (e tão diversos) eletrodos de trabalho. Sua boa vontade e suas idéias foram imprescindíveis ao desfecho deste e de tantos outros trabalhos do Laboratório de Caracterização de Interfases Eletroquímicas do IQ-USP.

Ao professor João Sena, da escola do Sindicato dos Joalheiros do estado de São Paulo, excelente artesão que investiu seu tempo na confecção de fios de liga áurica, sem nenhum fim pecuniário.

Aos professores doutores de minha banca de defesa, Neusa Alonso Faleiros (EP-PMT-USP) e Lúcio Angnes (IQ-QFL-USP), e de minha banca de qualificação, Idalina Vieira Aoki (EP-PQI-USP) e Liliana Marzorati (IQ-QFL-USP), por suas inestimáveis contribuições intelectuais.

A todos os professores e funcionários do IPT, do IQ-USP e da FCF-USP, que contribuíram direta ou indiretamente para a conclusão desta tarefa.

À minha esposa Priscila, pelas tantas revisões de textos já realizadas, além do constante apoio às minhas aspirações profissionais. 


\section{Ímdice}

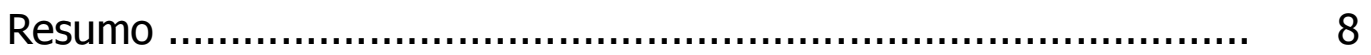

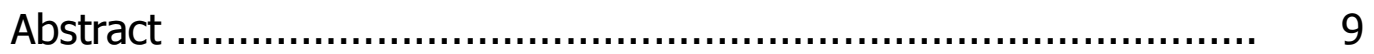

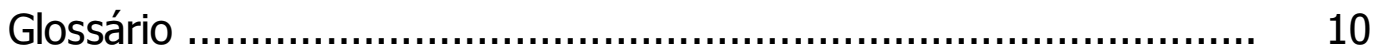

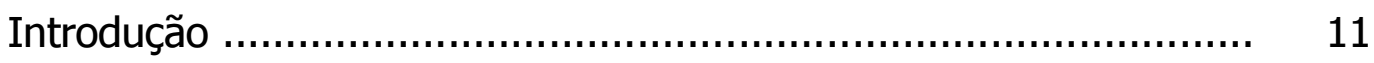

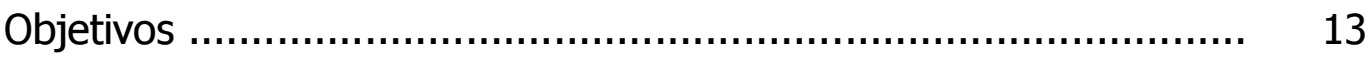

Capítulo 1: Revisão Bibliográfica ................................................. 14

1.1 Materiais metálicos usados em implantes, próteses e afins ...... 15

1.2 Corrosão em ambiente oral ................................................. 17

1.3 Influência das proteínas na corrosão de metais ........................ 18

1.4 Influência do íon fluoreto no ataque ao titânio ......................... 21

1.5 Resinas epóxi para embutimento de eletrodos de trabalho ....... 23

1.6 Resinas epóxi-vinil-éster .................................................. 25

Capítulo 2: Materiais e Métodos ...................................................... 29

2.1 Sistemas estudados ...................................................... 30

2.1.1 Metais de uso odontológico ..................................... $\quad 30$

2.1.2 Meios de ensaio …............................................. 31

2.1.3 Materiais de embutimento …................................ 32

2.2 Temperatura de estudo ................................................. 32

2.3 Confecção de eletrodos de trabalho ....................................... 32

2.4 Técnicas empregadas …................................................

2.4.1 Potencial de circuito aberto estacionário .................... $\quad 35$

2.4.2 Polarização potenciostática anódica .......................... 37

2.4.3 Microscopia eletrônica de varredura (MEV) ................ 38 
2.4.4 Espectroscopia por dispersão de energia (EDS) ........... 38

2.4.5 Espectrometria de absorção atômica de chama (FAAS) $\quad 38$

2.4.6 Espectroscopia de impedância eletroquímica (EIE) ...... 38

\section{Capítulo 3: Resultados com Discussão ........................................ $\quad 39$}

3.1 Desempenho dos materiais de embutimento .......................... 40

3.1.1 Avaliação do desempenho ....................................... 40

3.1.2 Interpretação dos resultados pela composição química $\quad 44$

3.2 Estudos eletroquímicos com a liga Au-Pt-Pd ......................... 46

3.3 Estudos eletroquímicos com a liga Ni-Cr-Mo-Ti ...................... 52

3.4 Estudos eletroquímicos com a amálgama de Ag-Sn-Cu-Zn ........ 57

3.5 Estudos eletroquímicos com o Ti-cp..................................... 62

3.6 Comparação entre o comportamento eletroquímico das ligas 66 Au-Pt-Pd e Ni-Cr-Mo-Ti

Capítulo 4: Conclusões e Sugestões para Trabalhos Futuros ......... 72

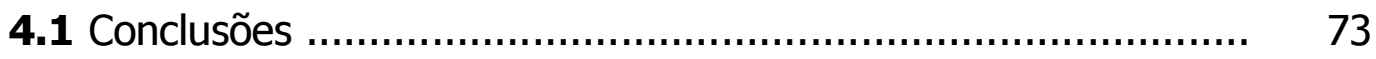

4.2 Sugestões para Trabalhos Futuros ...................................... 76

Referências Bibliográficas ......................................................... 77

Anexo (Curriculum Vitae) .............................................................. 80 


\section{Resumo}

\section{Interfases metal - solução eletrolítica de interesse odontológico} foram estudadas a $36,5^{\circ} \mathrm{C}$ por técnicas eletroquímicas estacionárias. Duas ligas, Au-Pt-Pd e Ni-Cr-Mo-Ti, foram comparadas e, neste caso, empregadas a impedância eletroquímica, a microscopia eletrônica de varredura e a espectroscopia de dispersão de energia. Os estudos também incluíram o Ti-cp e a amálgama Ag-Cu-Sn-Zn. Verificou-se o efeito da adição de NaF, de ácido cítrico $\left(\mathrm{H}_{3} \mathrm{Cit}\right.$ ) e de albumina de soro bovino (BSA) ao meio de $\mathrm{NaCl}$. A liga Ni-Cr-Mo-Ti, desenvolvida para substituir a liga Au-Pt-Pd, apresenta comportamento bem diverso da segunda, caracterizado por uma superfície irreprodutível, potencial de corrosão $200 \mathrm{mV}$ a $500 \mathrm{mV}$ mais negativo, dependendo do meio, e faixa passiva inexistente ou de pequena amplitude de potencial. O Ti-cp está passivado em todo o intervalo de potencial estudado ( $2 \mathrm{~V} / \mathrm{ECS}$ ) em meios de $\mathrm{NaCl}$ e $\mathrm{NaCl}+\mathrm{H}_{3} \mathrm{Cit}$; em $\mathrm{NaCl}+\mathrm{NaF}$, a faixa passiva é bem mais restrita, e a BSA a eleva de $100 \mathrm{mV}$. 0 $\mathrm{H}_{3} \mathrm{Cit}$ destrói o filme passivo sobre as ligas Ni-Cr-Mo-Ti e amálgama. A BSA exerce efeitos distintos dependendo da natureza do material metálico e do meio, sugerindo ora adsorção física, ora ação complexante. São discutidos diferentes tipos de embutimento para as amostras metálicas, como teflon, resinas epóxi e epóxi-vinil-éster (EVER). O embutimento com EVER é o mais recomendável para materiais de uso odontológico. 


\begin{abstract}
Different metal electrolytic interfases with relevance for dental prosthesis and implants were studied at $36,5^{\circ} \mathrm{C}$ by stationary electrochemical techniques. Two alloys, Au-Pt-Pd and Ni-Cr-Mo-Ti, were compared and in this case, EIS, SEM and EDS were also employed as techniques. The studies also included Ti-cp and $\mathrm{Ag}-\mathrm{Cu}-\mathrm{Sn}-\mathrm{Zn}$ amalgam. It was studied the effect of adding $\mathrm{NaF}$, citric acid $\left(\mathrm{H}_{3} \mathrm{Cit}\right)$ and bovine serum albumin (BSA) to $\mathrm{NaCl}$ medium. Ni-Cr-Mo-Ti alloy, developed to substitute Au-Pt-Pd alloy, presents a distinct behaviour from the last mentioned alloy, characterized by an irreproducible surface, corrosion potential situated at $200 \mathrm{mV}$ to $500 \mathrm{mV}$ more negative value, depending of the medium, and narrow or absence of passive range. Ti-cp is passive in all the potential range studied (2 $\mathrm{V} / \mathrm{SCE}$ ) in $\mathrm{NaCl}$ and $\mathrm{NaCl}+\mathrm{H}_{3} \mathrm{Cit}$ media; in $\mathrm{NaCl}+\mathrm{NaF}$ the passive range is narrower and it increases $100 \mathrm{mV}$ in the presence of BSA. $\mathrm{H}_{3}$ Cit breaks down the passive film deposited on the $\mathrm{Ni}-\mathrm{Cr}-\mathrm{Mo}-\mathrm{Ti}$ and amalgam alloy surfaces. BSA exhibits distinct effects depending upon both the nature of the alloy and the media suggesting either physical adsorption either complex formation. Different kinds of polymers for fitting the metallic samples are discussed, such as teflon, epoxy resin and epoxy vinyl ester resin (EVER). The results suggest that the EVER polymer is the most recommendable for fitting dental materials.
\end{abstract}




\section{Glossário}

araldite Marca de resina epóxi

branco $\quad \mathrm{NaCl} 9 \mathrm{~g} \cdot \mathrm{L}^{-1}$ presente em todas as soluções utilizadas

BSA Bovine serum albumin (albumina de soro bovino)

derakane Marca comercial de resina EVER usada neste trabalho (derakane 470)

E $\quad$ Potencial aplicado durante ensaios de polarização

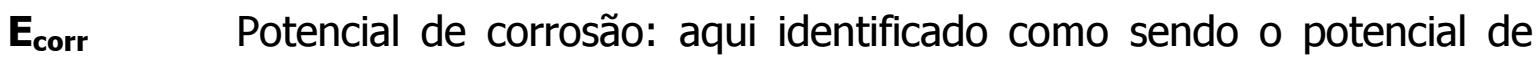
circuito aberto estacionário ou quase estacionário.

ECS Eletrodo de calomelano saturado

epofix Marca de resina epóxi

$\mathbf{E}_{\text {sc }} \quad$ Potencial de subida de corrente

EVER Epoxy vinyl ester resin (resina epóxi-vinil-éster): um tipo de resina epóxi modificada

FAAS Flame atomic absorption spectrometry (espectrometria de absorção atômica de chama)

FP $\quad$ Faixa passiva de potencial: diferença entre $\mathrm{E}_{\mathrm{sc}}$ e $\mathrm{E}_{\mathrm{corr}}$

$\mathbf{H}_{3}$ Cit $\quad$ Abreviação adotada para o ácido cítrico

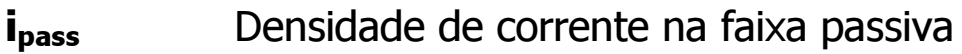

pI Ponto isoeletrônico: $\mathrm{pH}$ em que se iguala o total de cargas positivas e negativas de uma proteína.

$\mathbf{R}_{\text {pol }} \quad$ Resistência de polarização: resistência à passagem de corrente obtida das curvas de polarização potenciostática anódica, dada, em termos práticos, por $R_{p o l}=(\Delta E / \Delta i)$, nos trechos nos quais $E$ e i se relacionam de forma linear ou quase linear.

Ti-cp Titânio comercialmente puro

UP Unsaturated polyester (resina de poliéster insaturado) 


\section{Introdução}

O ouro, por tratar-se de metal nobre, com reconhecida inércia química, foi uma escolha evidente para a confecção de restaurações e próteses dentais. Sua baixa dureza, porém, obrigou os estudiosos da área de Odontologia a testar o uso de misturas desse metal com outros, como prata, platina e paládio. As ligas áuricas assim obtidas mantiveram bons resultados quanto à inércia química e mostraram propriedades físico-químicas adequadas ao uso odontológico, sendo ainda hoje largamente empregadas em ambiente bucal. Seu elevado custo, entretanto, suscitou a pesquisa e o desenvolvimento de diversos novos materiais metálicos menos dispendiosos, porém quimicamente menos nobres, como a amálgama (liga de mercúrio com outros metais, como prata, cobre, estanho e zinco, por exemplo) e várias ligas níquel-cromo, cada sistema objetivando substituir certa aplicação das ligas áuricas.

Além desses materiais metálicos, usados nas práticas de Odontologia mencionadas, a introdução de implantes para substituir raízes dentais trouxe para o ambiente oral o titânio (e suas ligas), bem sucedido nos implantes ortopédicos. $\mathrm{O}$ uso de sistemas formados por metais de menor potencial de redução que ouro, prata, platina e paládio justifica-se pela formação de filmes passivantes protetores, como é o caso do $\mathrm{TiO}_{2}$, que recobre o titânio comercialmente puro e muitas de suas ligas, protegendo suas próteses ortopédicas do ambiente a que são submetidas.

O ambiente oral, entretanto, possui uma composição de fluidos bem diferente - e aparentemente menos constante - do que o que se encontra nos arredores dos implantes ortopédicos, além de ser bastante mais aerado. A ingestão de alimentos variados, contendo sais, ácidos, bases e biomoléculas diversas, além de sua permanência por períodos desde segundos a horas (no caso de má assepsia, como falta de escovação, por exemplo), permite que se ponha em dúvida a real eficiência das camadas passivantes protetoras dos materiais 
constituídos por elementos menos nobres de uso odontológico. 0 próprio ín fluoreto, presente em diversos dentifrícios e enxaguantes bucais, pode apresentar um poder complexante similar (ou até maior, dependendo do sistema) ao do ín cloreto presente na saliva natural. Fazem-se necessários estudos de corrosão dos sistemas mencionados, a fim de que se verifique a resistência dos materiais metálicos atualmente em uso para os diversos procedimentos odontológicos.

Embora a albumina não seja tão abundante no meio oral quanto o é no plasma do sangue, esse trabalho também pretende ampliar, para materiais nãoferrosos aplicados em próteses e implantes dentários, os estudos já realizados neste laboratório $[7,12]$ sobre o efeito da albumina na corrosão de aços usados em implantes ortopédicos. 0 comportamento eletroquímico desses aços é alterado pela presença da proteína, de duas formas: (a) ação complexante, que se destaca quando se utilizam aços ricos em níquel, como o 316 L, favorecendo a dissolução do metal; (b) capacidade de adsorção, que fica evidenciada por tornar mais positivo o potencial de pite de materiais ferrosos, colaborando na formação de um filme protetor. Esses efeitos antagônicos já foram reportados por diferentes autores $[6,9,10,11]$, são comuns às proteínas em geral e dependem, para cada proteína, de sua concentração, da natureza e composição da solução em que ela se encontra dissolvida, da composição do material metálico testado e do potencial da interfase.

Dificuldades encontradas na confecção de eletrodos de trabalho, tais como infiltração das soluções de ensaios, seguida ou não de ataque ao polímero de embutimento, levaram ao uso de quatro tipos diferentes de polímeros, sendo um deles o teflon e os outros, diversas resinas de base epóxi. Decidiu-se, então, incluir nos objetivos deste trabalho um estudo sobre vantagens e desvantagens no uso dos polímeros testados. 


\section{Objetivos}

Os objetivos deste trabalho são:

I. Escolher, dentre duas opções tradicionais de polímeros (que são o teflon e as resinas de base epóxi), e uma variedade relativamente nova de resina (epóxi-vinil-éster), qual o material mais adequado para o embutimento de eletrodos de trabalho.

II. Realizar estudos eletroquímicos de materiais metálicos de amplo uso em obturações, próteses e implantes dentais - uma liga de Au-Pt-Pd, uma amálgama de $\mathrm{Ag}-\mathrm{Sn}-\mathrm{Cu}-\mathrm{Zn}$, o titânio comercialmente puro e uma liga de $\mathrm{Ni}-\mathrm{Cr}-\mathrm{Mo}-\mathrm{Ti}$ - em determinados meios passíveis de serem encontrados no ambiente oral. Foram escolhidos como meios de análise: soluções aquosas de cloreto de sódio, sempre presente nos fluidos corpóreos, na ausência e presença de fluoreto de sódio (presente em dentifrícios bucais) e de ácido cítrico (presente no suco de laranja e em outras frutas cítricas).

III. Avaliar a influência exercida pela albumina, proteína mais abundante do sangue e presente também em determinados alimentos, no comportamento das interfases metal-solução envolvendo os materiais metálicos e eletrólitos mencionados no item II. 
Capítulo 1: Revisão Bibliográfica 


\subsection{Materiais metálicos usados em implantes, próteses e afins}

Implantes dentários são raízes artificiais metálicas colocadas no osso maxilar e que terão a mesma função das raízes dos dentes naturais. Sobre o implante, é confeccionada a prótese, porção do dente que se visualiza quando a boca está aberta. Os implantes também são utilizados para reter e estabilizar próteses totais (dentaduras) em pacientes em que as próteses não se mantêm fixas. As restaurações consistem no fechamento de depressões a fim de devolver ao dente sua topografia superficial de origem e sua eficiência na mastigação. São comumente formadas de material resinoso ou de amálgamas de prata com outros metais. Se a área a ser reconstituída ultrapassa certo percentual, uma coroa ou prótese substitui a restauração. Nesses casos, os materiais mais usados são as ligas áuricas e de níquel-cromo. As obturações são fechamentos de canais perfurados no dente, pela introdução de cimento apropriado (figura 1).

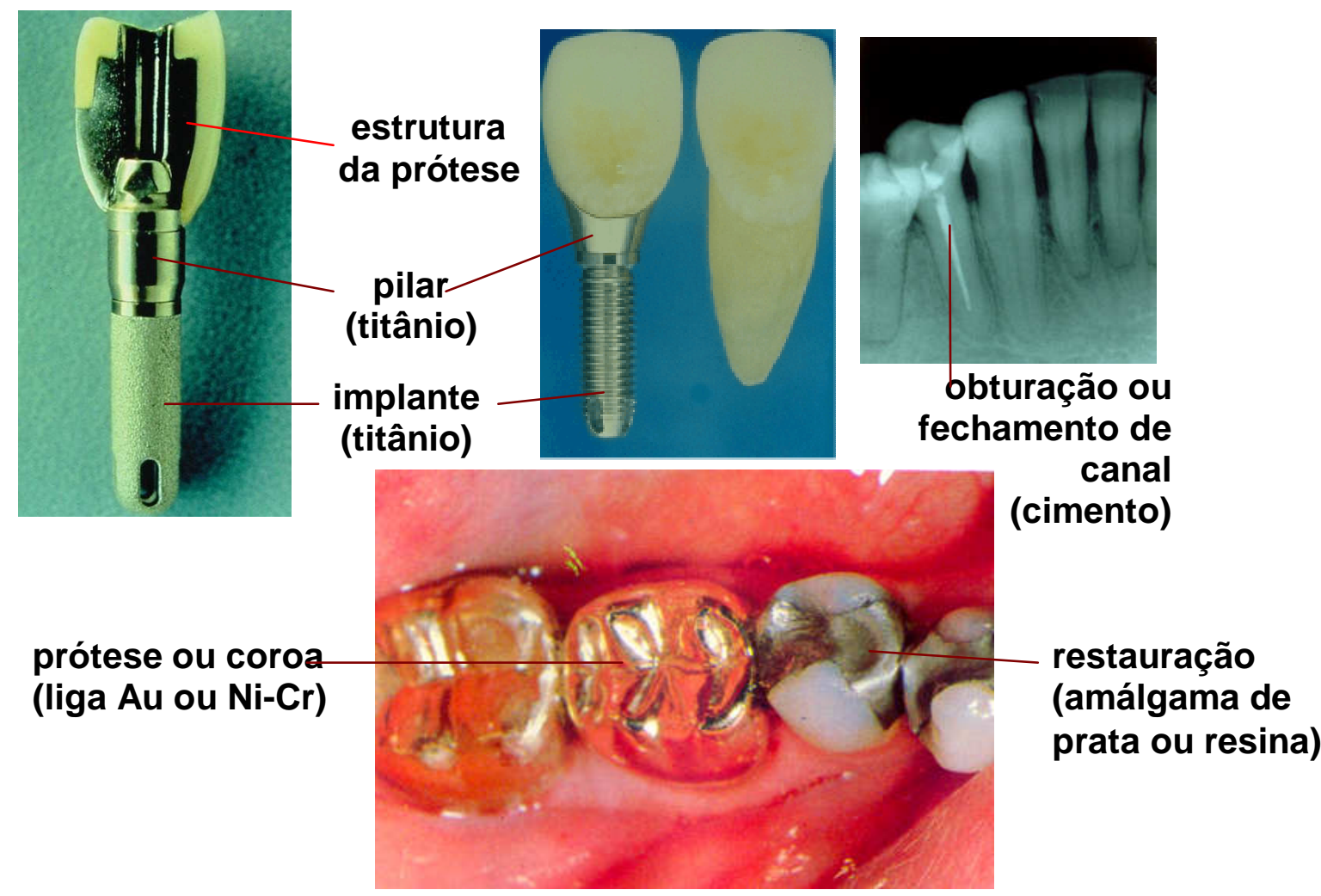

Figura 1. Exemplos de implantes, próteses, coroas, obturações e restaurações dentários 
Segundo Phillips [1], a utilização do ouro em próteses dentárias está descrita na literatura desde 1907, quando Taggart introduziu a técnica da fundição de incrustações restauradoras. Essa técnica foi um sucesso imediato, e logo se desenvolveram as restaurações metálicas fundidas, coroas, próteses fixas e próteses removíveis. Como o ouro puro não apresentava propriedades essenciais, como dureza apropriada, por exemplo, para esses tipos de restauração e aparelhos, ligas existentes em joalheria foram rapidamente adotadas. Elas eram ligas de ouro com resistência aumentada pelo cobre, prata e platina. Nas primeiras ligas áuricas dentárias, o ouro, a prata e a platina foram considerados os únicos metais nobres capazes de prover estabilidade química no ambiente bucal. Em 1948, apareceu a lista de composições de ligas dentárias de metais nobres. Os metais considerados nobres são: ouro, platina, metais do grupo da platina (paládio, ródio, rutênio, irídio e ósmio) e prata. Desses oito, quatro são correntemente de maior importância na fundição dentária: ouro, paládio, platina e prata. Os três primeiros são inertes na cavidade bucal. A prata, desde que em liga com quantidades substanciais de paládio, resiste igualmente à corrosão. $\mathrm{O}$ irídio e o rutênio podem ser mencionados como aqueles que têm um papel menor, como elementos-traço para o refinamento dos grãos das ligas dentárias com base em ouro e paládio.

De acordo com o mesmo autor, a pressão econômica, bem como a pesquisa de propriedades mecânicas melhoradas, levou ao desenvolvimento de outras ligas para a construção de aparelhos dentários protéticos. Nos anos 30, as ligas de cromo-cobalto-níquel foram escolhidas para a fabricação de estruturas de próteses parciais removíveis, sendo o cromo essencial para proporcionar passivação e resistência à corrosão. Com o sucesso, houve um interesse para a aplicação dessas mesmas ligas na fabricação de pequenas fundições.

Adell et alii [2] relatam que, de 1965 a 1980, foram instalados cerca de três mil implantes osseointegrados de titânio, com bons resultados.

As ligas de titânio da classe $\alpha+\beta$ são as mais comuns dentre os vários tipos. A Ti-6Al-4V é a mais conhecida, por possuir estrutura cristalina hexagonal compacta (fase $\alpha$ ) e cúbica de corpo centrado (fase $\beta$ ), presentes à temperatura 
ambiente, combinando resistência mecânica e resistência à corrosão com conformabilidade e usinabilidade. Com excelentes relações resistência/peso e ótima resistência à corrosão, as ligas de titânio têm sido um excelente atrativo para aplicações nas indústrias aeronáutica e automobilística, e na fabricação de próteses ortopédicas (Acciari et alii [3]).

A amálgama é um tipo especial de liga, na qual um dos constituintes é o mercúrio. Como ele é líquido à temperatura ambiente, pode se agregar a outros tipos de metais que estejam em estado sólido. Esse tipo de formação de liga é amplamente conhecido como amalgamação. Uma das razões para o desempenho clínico com registro excepcionalmente bom para a amálgama é a diminuição da infiltração marginal, devida provavelmente a uma pequena expansão da liga quando de sua cristalização na cavidade dentária.

\subsection{Corrosão em ambiente oral}

Biocompatibilidade é a habilidade de um material em se adaptar a um hospedeiro numa aplicação específica. Isso significa que o tecido de um paciente, que entra em contato com dado material, não deve sofrer nenhuma ação tóxica, carcinogênica, inflamatória, alérgica, mutagênica e irritação. Já que o ambiente oral é particularmente favorável à biodegradação de metais devido às suas propriedades iônica, térmica, microbiológica e enzimática, pode-se presumir que o paciente é exposto, em certa extensão, aos produtos de corrosão dos materiais metálicos nele implantados. Com o aumento da corrosão de uma liga e a liberação de seus elementos, reações indesejáveis que ocorrem nos tecidos podem ser realçadas. Tais reações incluem sabores desagradáveis, irritação e alergia (Fathi et alii [4]).

A maioria das ligas usadas para restauração bucal, mantidas permanentemente em contato com os eletrólitos da saliva, sofre uma lenta e progressiva degradação, como resultado da corrosão eletroquímica. O grau de resistência à corrosão, portanto, constitui-se um bom critério na utilização de um material biometálico no meio oral, daí um grande número de estudos ter levado à 
produção de materiais com maior resistência à corrosão. 0 titânio, largamente empregado em restauração cirúrgica, é geralmente considerado o melhor material na constituição de implantes orais. Apesar do gasto energético resultante de seu alto ponto de fusão $\left(1668{ }^{\circ} \mathrm{C}\right)$, esse metal é usado para a produção de elementos protéticos, e diversas investigações estão em andamento para otimizar as propriedades mecânicas e corrosivas de suas ligas. Embora possua potencial eletroquímico bastante negativo (-1,63 V / ECS), sua grande resistência à corrosão deve-se principalmente à formação, em sua superfície, de um filme passivante altamente protetor, com espessura entre 10 e $20 \mathrm{~nm}$, o qual pode conter TiO, $\mathrm{Ti}_{2} \mathrm{O}_{3}$ e $\mathrm{TiO}_{2}$. Este último óxido é o mais comumente encontrado e citado na literatura como principal responsável pela sua resistência à corrosão. 0 contato entre o implante metálico e os tecidos receptores é feito por intermédio da superfície recoberta por esse óxido. De fato, as propriedades químicas e a estrutura cristalina das camadas de óxido externas condicionam o processo de osseointegração. A comprovada biocompatibilidade do titânio, como material de implante, é, então, outra conseqüência das propriedades superficiais de seus óxidos, segundo um grande número de autores que têm estudado o comportamento eletroquímico das ligas de titânio usadas em Odontologia. As características mecânicas dessas ligas, cuja proporção em Ti varia entre 85 e $95 \%$, são melhoradas pela adição de alumínio, níquel, cobre ou vanádio, mas a passividade é mantida próxima ou igual à do titânio puro (Toumelin-Chemla et alii [5]).

\subsection{Influência das proteínas na corrosão de metais}

Tem sido consideravelmente interessante, recentemente, o estudo do comportamento interfacial das proteínas, tanto na indústria de alimentos (devido aos problemas associados à retenção de sujeira) quanto na área de implantes médicos e de biossensores (devido a problemas com crescimento bacteriano e dissolução de metal). Para casos como esses, deseja-se o mínimo de adsorção de proteínas. Existem, entretanto, outros exemplos em que a adsorção de proteínas nas superfícies é desejada, como na imobilização e separação de enzimas para 
aplicações biotecnológicas. As interações entre proteínas e superfícies, resultando na adsorção, dependem de suas propriedades, bem como de outros parâmetros, como pH, concentração e temperatura do sistema (Omanovic et alii [6]).

A literatura apresenta algumas discordâncias em relação ao efeito catalisador ou inibidor causado pela proteína. Essas discordâncias podem ser atribuídas à utilização de diferentes concentrações de proteína, bem como à diferença na composição do material metálico em consideração. A soro-albumina, proteína existente em maior quantidade no plasma sangüíneo, é a que desperta maior interesse no estudo de caracterização de ligas metálicas aplicadas em implantes (Afonso et alii [7]).

Wataha et alii [8], trabalhando com ligas contendo $0-94 \%$ de metais nobres e soluções salinas $(0,85 \% \mathrm{NaCl})$, salinas com albumina de soro bovino (Bovine Serum Albumin - BSA) a 3\%m/v e com meio de cultura celular em $3 \%$ de soro, observaram que houve, em geral, maior liberação de elementos em solução salina-BSA do que em solução apenas salina. Esse comportamento foi observado para $\mathrm{Ag}, \mathrm{Cu}, \mathrm{Pd}$ e $\mathrm{Zn}$, mas não para Ni. A liberação de $\mathrm{Ni}$ da liga $\mathrm{Ni}-\mathrm{Cr}$ foi menor na presença de BSA.

Omanovic e Roscoe [9], estudando o comportamento da BSA num aço inoxidável (26 a $\left.70{ }^{\circ} \mathrm{C}\right)$, observaram uma adsorção muito intensa de moléculas de proteína, acompanhada por um processo de transferência de carga envolvendo quimissorção. Uma explicação foi dada, sugerindo a interação dos grupos carboxilato das proteínas, carregados negativamente, com a superfície do aço.

Merritt e Brown [10] observaram, em seus experimentos, dissolução preferencial de $\mathrm{Ni}$, em relação a $\mathrm{Cr}$, em ligas $\mathrm{Ni}-\mathrm{Cr}$, na presença de soro-proteínas (0,5\%m albumina, 0,25\%m gama globulina, 0,03\%m fibrinogênio e 0,01 \%m transferina, dissolvidas em solução de $\mathrm{NaCl} 0,15 \mathrm{M}$ ). Relataram que um mecanismo pelo qual as proteínas devem afetar a taxa de corrosão é o efeito direto da polarização que uma carga positiva ou negativa causa na superfície do implante: como zwitter íons (ou íons anfólitos - zwei, do alemão, quer dizer dois), as proteínas têm, em soluções ácidas em relação ao seu ponto isoeletrônico (pI), 
uma carga positiva e, em soluções básica em relação ao seu pI, uma carga negativa, conforme demonstrado na figura 2. Isso se deve aos grupos carboxila e amino presentes nos aminoácidos que as formam. Variações de pH não mudaram a taxa de corrosão de implantes metálicos em soluções salinas, mas alteraram em soluções de albumina. Em soluções ácidas (em relação ao seu pI), a presença da carga positiva na albumina não alterou a taxa de corrosão, comparada com a das soluções salinas. No entanto, a presença da carga negativa em soluções básicas (em relação ao seu pI) diminuiu a taxa de corrosão.

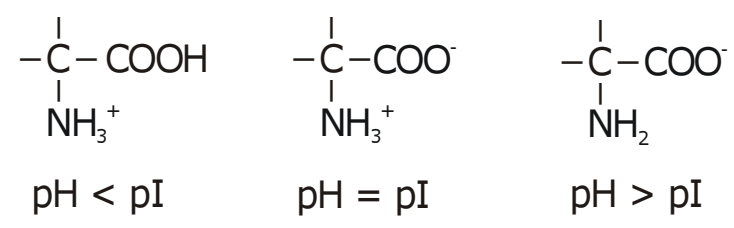

Figura 2. Efeito do $\mathrm{pH}$ na distribuição de cargas de um aminoácido ou de uma proteína.

O surgimento de cargas positivas na matriz metálica, seja devido à dupla camada elétrica, seja devido a processos de transferência de elétrons inerentes à corrosão metálica, pode favorecer a adsorção dos íons carboxilato negativos das proteínas desprotonadas pelo $\mathrm{pH}$ básico (em relação ao seu pI). Tal camada proteica, uma vez ancorada à superfície metálica, diminuiria seu contato com o meio externo corrosivo, tal como fazem as camadas de óxidos metálicos passivantes.

Assim, o efeito das proteínas na taxa de corrosão depende de sua carga. 0 soro é composto por uma variedade de proteínas que têm diferentes pontos isoeletrônicos. No pH fisiológico, algumas das proteínas terão uma carga negativa líquida e outras, uma carga positiva. Desde que a carga líquida possa ser alterada sem alterar a estrutura da proteína, por ajuste do pH da solução, o efeito sobre a taxa de corrosão, das proteínas carregadas positiva ou negativamente poderá ser estudado. Muitos pesquisadores têm escolhido, para estudo, as proteínas de maior concentração no soro comum e também as comercialmente acessíveis (albumina, gama globulina, transferina e fibrinogênio). 
Huang [11] relatou que a presença de proteína BSA em fosfato salino tamponado aumentou a resistência à corrosão do Ti-6Al-4V, mas diminuiu a do Ti-13Nb-13Zr e do Ti-6Al-7Nb.

Por fim, resultados obtidos pelo grupo de Caracterização de Interfases Eletroquímicas do IQ-USP, em particular Afonso et alii [12], num estudo para verificar o efeito da albumina $\left(0 ; 2 ; 20 \mathrm{mg} \mathrm{L}^{-1}\right)$ sobre aços, em meios de $\mathrm{NaCl}$ $0,11 \mathrm{~mol} \mathrm{~L}^{-1}$, à temperatura de $36{ }^{\circ} \mathrm{C}$, sugerem uma tendência dessa proteína, em baixas concentrações, de atuar como complexante e, em concentrações mais elevadas, de ampliar a região passiva dos aços com maior teor de níquel.

\subsection{Influência do íon fluoreto no ataque ao titânio}

Toumelin-Chemla et alii [5], em sua pesquisa bibliográfica, verificaram que, mesmo uma pequena quantidade de fluoreto (os autores não mencionaram valores), em meio de certos ácidos, induz a reações como as exemplificadas a seguir:

$$
\begin{gathered}
\mathrm{NaF}+\mathbf{H}^{+} \rightleftharpoons \mathrm{HF}+\mathrm{Na}^{+} \\
\mathrm{TiO}_{2}+\mathbf{2 H F} \rightleftharpoons \mathrm{H}_{2} \mathrm{O}+\mathrm{TiOF}_{\mathbf{2}}
\end{gathered}
$$

No primeiro equilíbrio, a formação de HF é possível pelo fato de este tratar-se de ácido de força moderada a baixa $(\mathrm{pK}=3)$. Os oxifluoretos de titânio sólidos, gerados no segundo equilíbrio, causam muitos defeitos estruturais na cobertura de óxido, cuja proteção é consideravelmente danificada. O mesmo artigo tem uma descrição bastante completa do histórico do uso de géis contendo fluoreto: durante os últimos quarenta anos, a aplicação profilática de géis e soluções contendo altas concentrações desse ín tem sido cada vez mais freqüente, graças ao seu impacto na prevenção à cárie dental. Tais géis consistem em preparados ácidos fluoretados, com pH geralmente entre 3,2 e 7,7. Soube-se de uma redução significante de gengivite por escovação duas vezes ao dia com gel de $\mathrm{SnF}_{2}$ contendo 1000 ppm de fluoreto, de $\mathrm{pH}=3$. Um gel de $\mathrm{NaF}$, com a 
mesma concentração do ânion, mas $\mathrm{pH}=7$, tem resultados duas vezes inferiores. Assim, têm surgido no mercado géis com até 10000 ppm de fluoreto, com $\mathrm{pH}=5,5$ (Fluorgel, Labo. Dentoria, França), concentrações que podem ser muito perigosas para a resistência à corrosão de materiais metálicos presentes no ambiente bucal.

Huang [11] relata que os fluoretos (na forma, p.e., de $\mathrm{NaF}$ e/ou $\mathrm{Na}_{4} \mathrm{FPO}_{4}$ ) existentes nas pastas de dentes comerciais e géis profiláticos, usados oralmente e topicamente para prevenção de cáries ou para aliviar a sensibilidade, podem estar na faixa de 0,1 a 2\% (1 000 a 20000 ppm) e que, quando o eletrólito penetra nas fendas da cavidade oral, não é facilmente retirado, restando fluoreto no local. Investigando o efeito da concentração desse íon e de albumina no comportamento corrosivo da liga Ti-6Al-4V, em saliva artificial ácida $\left(\mathrm{pH}=5\right.$ a $\left.37^{\circ} \mathrm{C}\right)$, esse autor observou que tanto a presença de $\mathrm{NaF}(0-0,5 \%)$, quanto de albumina $(0-0,2 \%)$ em meio de $\mathrm{NaF}$ 0,1\% tiveram uma significante influência no potencial de corrosão $\left(E_{\text {corr }}\right)$, taxa de corrosão ( $\left.i_{\text {corr }}\right)$, densidade de corrente passiva (i pass $\left._{\text {par }}\right)$, e resistência à polarização $\left(R_{p o l}\right)$. Os valores de $i_{\text {corr }}$ e $i_{\text {pass }}$ aumentaram com $o$ aumento da concentração de NaF, mas diminuíram na presença de albumina em meio de NaF. $\mathrm{O}$ valor de $\mathrm{R}_{\text {pol }}$ diminuiu com o aumento da concentração de $\mathrm{NaF}$, mas aumentou na presença de albumina em meio de NaF. Quando a concentração de $\mathrm{NaF}$ foi maior do que $0,1 \%$, as características protetoras do filme passivo de $\mathrm{TiO}_{2}$, formado na liga Ti-6Al-4V, foram destruídas pelos íons fluoreto, pela formação, segundo o autor, de $\mathrm{Na}_{2} \mathrm{TiF}_{6}$. A presença da albumina, independentemente da concentração, melhorou a resistência à corrosão da liga Ti-6Al-4V.

Jesuíno et alii [13], investigando a corrosão da liga Ti-6Al-4V, após imersão por quatro meses em solução fisiológica $(\mathrm{NaCl} 1 \% \mathrm{~m} / \mathrm{m})$ e de $\mathrm{NaCl} 1 \% \mathrm{~m} / \mathrm{m}+\mathrm{NaF}$ $0,1 \% \mathrm{~m} / \mathrm{m}$, observaram aumento do $\mathrm{pH}$ nas duas soluções, em particular na última, além de ataque por pite. Concluíram que a formação de pites deveu-se à presença de haletos, havendo dissolução do filme protetor por complexação, citando como bem conhecido o efeito complexante do ín fluoreto, que era seguido por hidrólise dos ânions formados, contribuindo para o aumento do $\mathrm{pH}$ : 


$$
\begin{aligned}
\mathrm{TiF}_{6}{ }^{2-}+6 \mathrm{H}_{2} \mathrm{O} & \rightleftharpoons 6 \mathrm{HF}+\left[\mathrm{Ti}(\mathrm{OH})_{2}\right]^{2+}+4 \mathrm{OH}^{-} \\
\mathrm{AlF}_{6}{ }^{3-}+12 \mathrm{H}_{2} \mathrm{O} & \rightleftharpoons 6 \mathrm{HF}+\left[\mathrm{Al}(\mathrm{OH})_{6}\right]^{3+}+6 \mathrm{H}^{-}
\end{aligned}
$$

Fovet et alii [14] observaram, em solução Ringer, que a solubilização da forma $\mathrm{TiO}_{2}$ deixa de ocorrer apenas em meios fortemente ácidos $(\mathrm{pH}=1,2)$ e passa a se dar também em meios de acidez branda $(\mathrm{pH}=6,1)$ quando $\mathrm{o}$ ín fluoreto se encontra presente.

\subsection{Resinas Epóxi para Embutimento de Eletrodos de Trabalho}

A palavra epóxi vem do grego ep (sobre ou entre) e do inglês oxi (oxigênio), significando literalmente oxigênio entre carbonos. Em um sentido geral, o termo refere-se a um grupo constituído por um átomo de oxigênio ligado a dois átomos de carbono. 0 grupo epóxi mais simples é aquele formado por um anel de 03 elementos, ao qual o termo $\alpha$-epóxi ou 1,2-epóxi é aplicado. 0 óxido de etileno é um exemplo desse tipo. Os termos 1,3 e 1,4-epóxi são aplicados, respectivamente, aos óxidos de trimetileno e de tetra-hidrofurano, já o grupo glicidil é usado como referência de grupo epóxi terminal, sendo o nome completado por éster, éter, amina etc., de acordo com a natureza do grupo ligado ao terceiro carbono (figura 3 ).

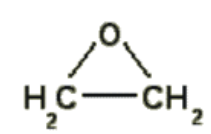

Óxido de etileno

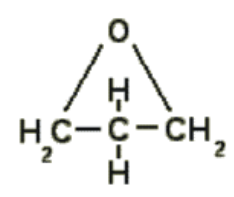

Óxido de trimetileno

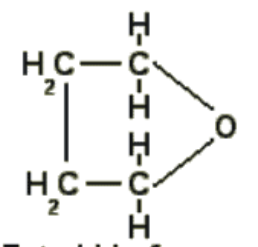

Tetrahidrofurano

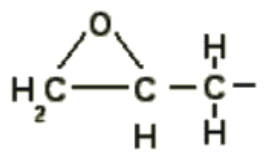

Grupo Glicidil

Figura 3. Alguns exemplares simples de epóxi

A primeira resina epóxi comercial foi o produto da reação de epicloridrina (cloreto de glicidil) com bisfenol-A (este sendo, por sua vez, resultado da reação de dois grupos fenol com a acetona: o A de bisfenol-A vem de acetona), gerando assim a resina epóxi mais comum, conhecida como diglicidil éter de bisfenol-A (DGEBA). Segundo G. Challa [15], inicialmente formam-se cadeias lineares pela reação de excesso de epicloridrina com bisfenol-A em meio alcalino (figura 4). 
<smiles>COCCCl</smiles><smiles>Oc1ccccc1</smiles><smiles>CC(C)(C)c1ccc(O)cc1</smiles>

$\mathrm{NaOH}$<smiles>CC(C)(c1ccc(OCC2CO2)cc1)c1ccc(OCC2CO2)cc1</smiles>

Figura 4. Obtenção de diglicidil éter de bisfenol-A

Se é usado um excesso um pouco maior de epicloridrina, grupos epóxi terminais abrem-se para reação com grupos hidroxil de bisfenol-A que não haviam reagido, resultando uma cadeia mais extensa de pré-polímero, ainda de baixa massa molecular (figura 5).<smiles>COCC(C)CCOc1ccc(C(C)(C)c2ccc(OCC(O)CC(C)(C)c3ccc(OCC4CO4)cc3)cc2)cc1</smiles>

Figura 5. Diglicidil éter de bisfenol-A obtido com maior excesso de epicloridrina.

A molécula da figura 5 é a resina epóxi antes de ser catalisada, podendo, de acordo o valor de $n$, ser líquida a sólida, aumentando-se a viscosidade à medida que $n$ aumenta. Esse pré-polímero é, então, novamente polimerizado, dessa vez dentro de um molde, gerando ligações cruzadas e estrutura de termofixo, por reação com aminas alifáticas polifuncionais (figura 6).

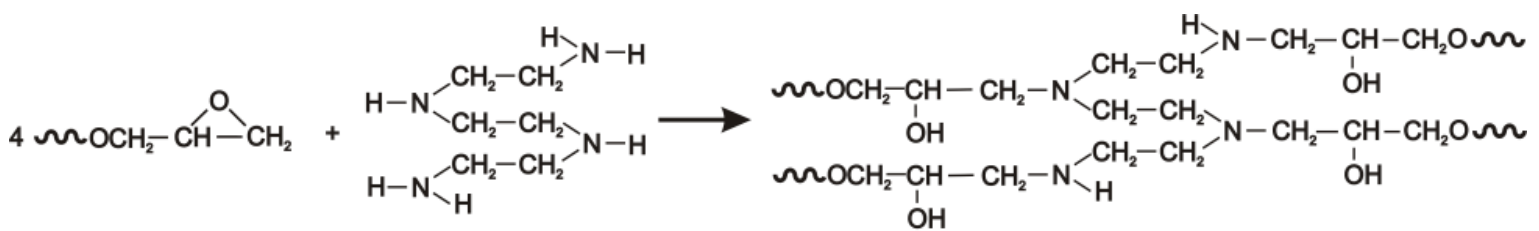

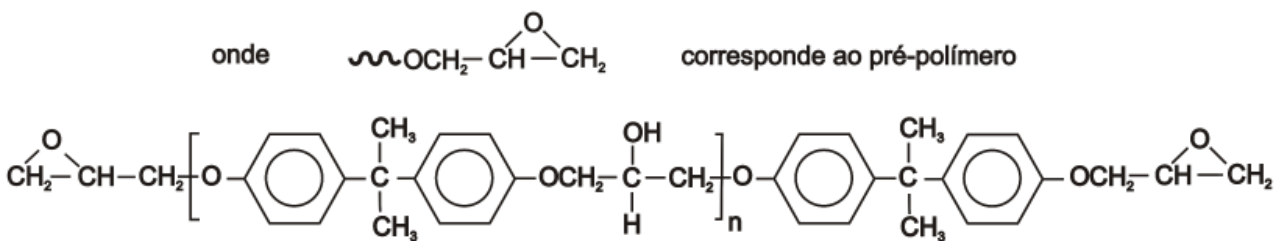

Figura 6. Etapa final de polimerização de uma epóxi típica 


\subsection{Resinas Epóxi-Vinil-Éster}

Segundo A. MacInally [16], epóxi-vinil-éster (Epoxy Vinyl Ester Resins EVERs) são baseadas em resinas epóxi, modificadas de tal modo que possam ser curadas pelo mesmo método das tradicionais resinas de poliéster insaturado (unsaturated polyester - UP), ou seja, por mecanismo de radicais livres com estireno como co-monômero de cura. A descrição química seguinte terá como base a estrutura de uma resina epóxi do tipo bisfenol-A, mas uma EVER pode ser produzida a partir de quase qualquer tipo de resina epóxi, dependendo das propriedades desejadas. Por exemplo, uma resina epóxi baseada em novolaca terá resistência térmica mais alta; resina epóxi de tetrabromo-bisfenol-A melhora a resistência ao fogo devido ao seu conteúdo de bromo; resina epóxi de borracha modificada pode ser usada para dar alta resistência ao impacto.

Reage-se um mol de pré-polímero de resina epóxi, na presença de catalisadores, com 2 mols de ácido metacrílico. Os grupos ácidos reagem com os grupos epóxi para formar acoplamentos de éster, deixando dois grupos vinil reativos na posição terminal de cada molécula, daí o nome epóxi-vinil-éster (figura 7).

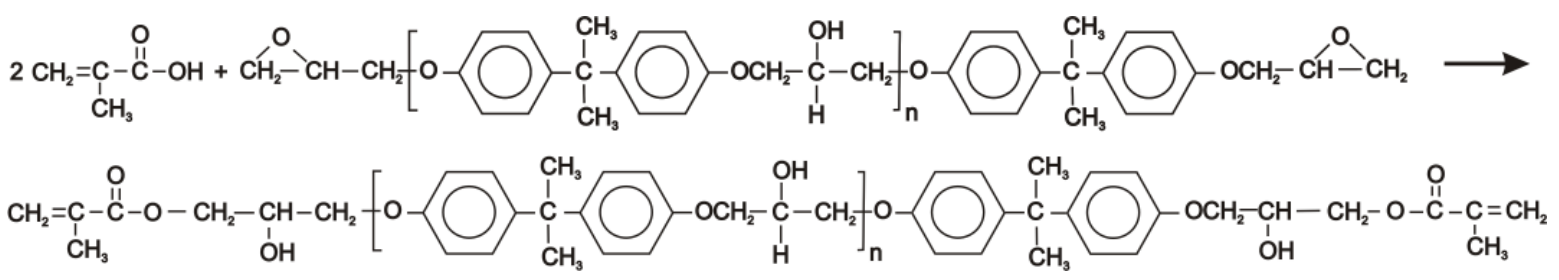

Figura 7. Obtenção de uma resina epóxi-vinil-éster baseada em bisfenol-A

Esta resina é, então, dissolvida em estireno (que faz papel de solvente e copolímero) e pode ser curada com peróxidos e aceleradores, da mesma maneira que qualquer resina UP convencional. O uso da estrutura epóxi confere à resina curada final o bom desempenho desse tipo de polímero, aliado à processabilidade e às características de cura das resinas UP.

Derakane 470, utilizada neste trabalho, é uma EVER baseada em novolaca epoxidisada. 
G. Challa [15] afirma que as novolacas são resinas do tipo fenolformaldeído, e a baquelite, desenvolvida por Baekeland em 1907, foi a primeira representante comercial dessa classe de polímeros, com aplicação em lacas, adesivos, tintas e compósitos de enchimento inerte. Num dos processos de síntese dessas resinas, obtêm-se inicialmente novolacas de baixa massa molecular pela reação de formaldeído com excesso de fenol, sob catálise ácida. 0 formaldeído produz grupos $-\mathrm{CH}_{2} \mathrm{OH}$ nos anéis de fenol, que reagem com átomos de $\mathrm{H}$ ativos de outros fenóis, com eliminação de água e formação de pontes de metileno (figura 8).

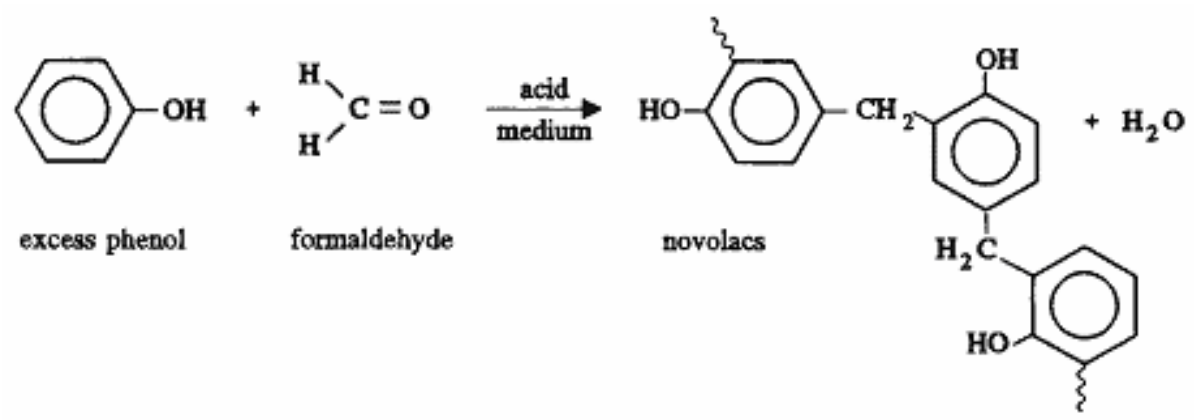

Figura 8. Primeira etapa de produção de novolacas pela rota de duas etapas.

Esse produto é, então, aquecido com formaldeído extra, que conecta unidades fenol de diferentes cadeias por novas pontes de metileno, obtendo-se a novolaca, que deve possuir uma estrutura equivalente à da figura 9 , já que o grupo hidroxila, por ser orto-para dirigente, introduz as pontes de metileno nessas posições.

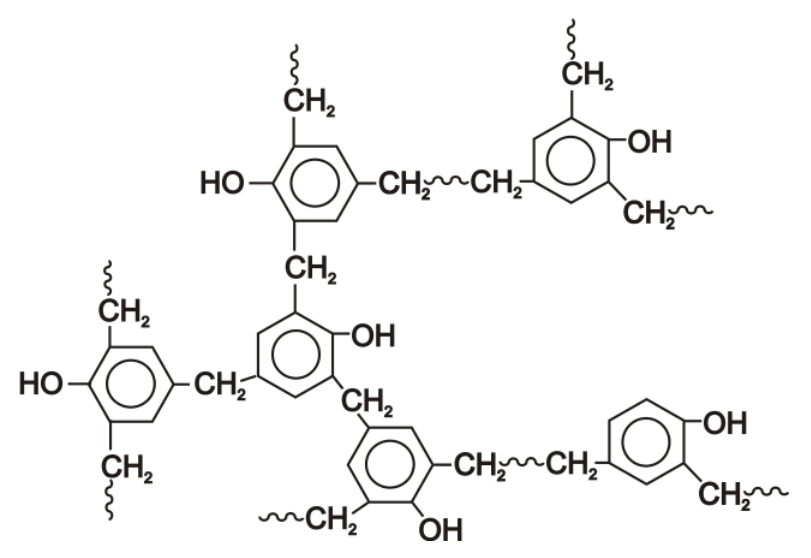

Figura 9. Representação da estrutura de uma novolaca. 
Por comparação com o que ocorreu na epoxidização de resina a base de bisfenol-A (figura 4, p. 24), também para a novolaca a fixação dos grupos epóxi deve dar-se pela reação da epicloridrina com os grupos hidroxila aromáticos (figura 10).

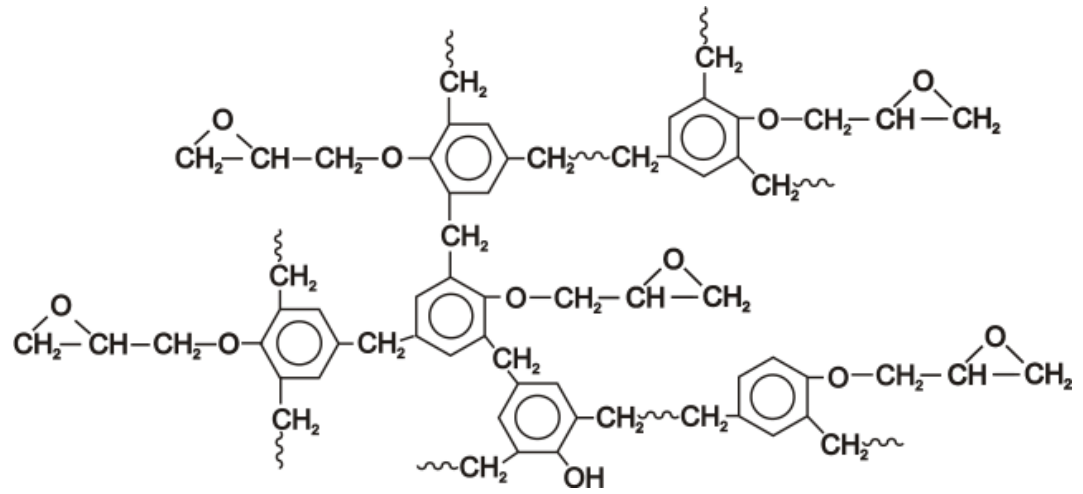

Figura 10. Representação da estrutura de uma novolaca epoxidisada.

A resina epóxi à base da novolaca da figura 10 está pronta para reagir com ácido metacrílico e gerar, assim, o pré-polímero de EVER, descrito por A. MacInally [16] como o que resulta derakane 470. O ácido metacrílico ataca os grupos epóxi, resultando a estrutura representada na figura 11.

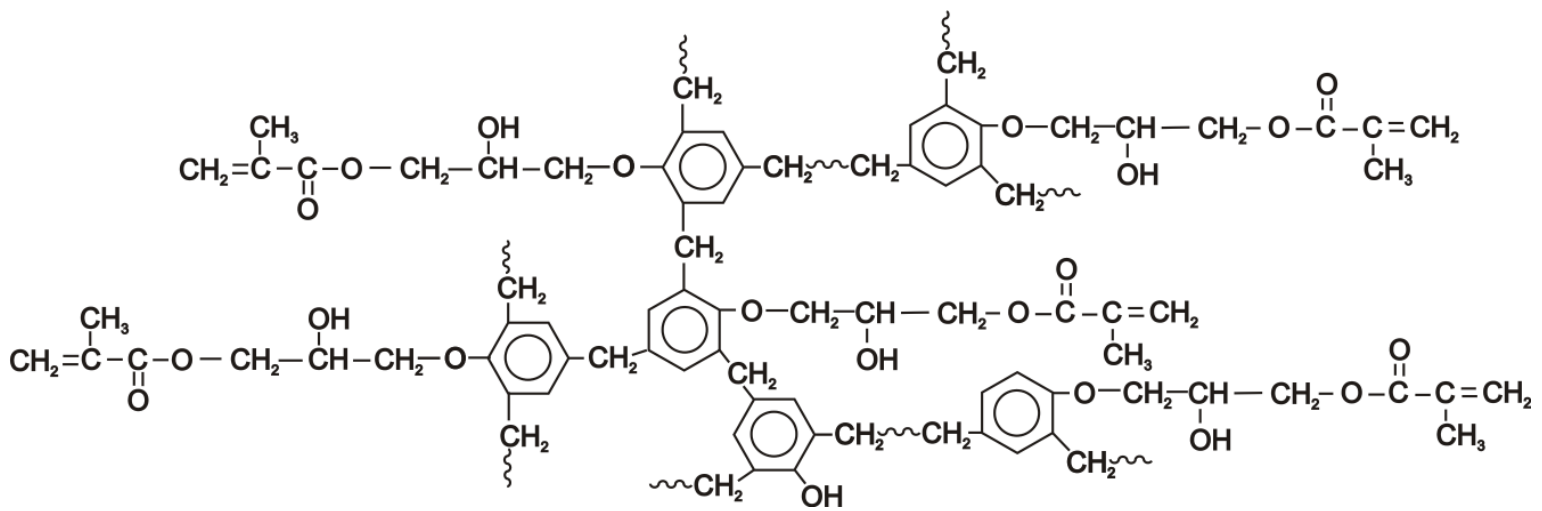

Figura 11. Representação da estrutura do pré-polímero de derakane 470.

Essa EVER é fornecida pelo fabricante, dissolvida em $33 \%$ de estireno, que é seu copolímero de cura. Uma vez introduzida no molde, essa mistura é polimerizada por reação de adição entre os grupos vinil da resina e do estireno, quando se adicionam os agentes de cura, segundo a reação ilustrada na figura 12 . 


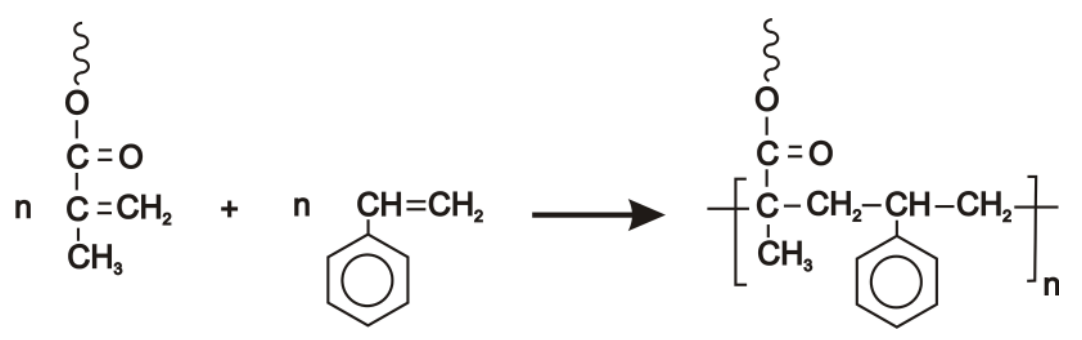

Figura 12. Polimerização por adição da EVER derakane 470 com estireno. 
Capítulo 2: Materiais e Métodos 


\subsection{Sistemas estudados}

\subsubsection{Metais de uso odontológico}

a) Titânio comercialmente puro grau 4, usado para implantes: mínimo de 99,5\%m Ti com máximos dos seguintes constituintes (\%m): C $(0,10), \mathrm{Fe}$ $(0,05), \mathrm{N}(0,05), \mathrm{O}(0,40), \mathrm{H}(0,015)$ - norma ASTM F468 Gr4.

b) Liga Au-Pt-Pd Degudent- $U^{\circledR}$ (Degussa - Brasil), indicada para uso em coroas e pontes. Uma amostra dessa liga foi analisada e sua composição, determinada por espectrometria de absorção de chama (FAAS). Os resultados, obtidos de análises em duplicata, estão na tabela 1, dispostos contra a composição nominal dada pelo fabricante.

Tabela 1 - Comparação das composições mássicas percentuais da análise FAAS com a nominal fornecida pelo fabricante da liga áurica.

\begin{tabular}{lrrrrrrrrrrc}
\hline & $\mathrm{Au}$ & $\mathrm{Pt}$ & $\mathrm{Pd}$ & $\mathrm{In}$ & $\mathrm{Ag}$ & $\mathrm{Sn}$ & $\mathrm{Cu}$ & $\mathrm{Re}$ & $\mathrm{Fe}$ & $\mathrm{Ir}$ & $\mathrm{K}$ \\
\hline FASS & 75,1 & 10,0 & 13,9 & - & 1,1 & - & - & - & - & - & $<0,05$ \\
nominal & 77,3 & 9,8 & 8,9 & 1,5 & 1,2 & 0,5 & 0,3 & 0,2 & 0,2 & 0,1 & - \\
\hline
\end{tabular}

c) Amálgama dentária, utilizada para confecção de obturações, obtida da homogeneização de mercúrio $(50 \% \mathrm{~m})$ com uma liga de $\mathrm{Ag}-\mathrm{Sn}-\mathrm{Cu}-\mathrm{Zn}$ (\%m: 69,3 - 17,9 - 11,8 - 1), chamada Dispersalloy ${ }^{\circledR}$ (Dentsply - Brasil).

d) Liga Ni-Cr-Mo-Ti Tilite ${ }^{\circledR}$ (Talladium - Brasil), indicada para substituir as ligas áuricas nas suas aplicações. Uma amostra dessa liga foi analisada e sua composição determinada por espectrometria de absorção de chama (FAAS). Os resultados, obtidos de análises em duplicata, estão na tabela 2, dispostos contra a composição nominal dada pelo fabricante.

Tabela 2 - Comparação das composições mássicas percentuais da análise FAAS com a nominal fornecida pelo fabricante da liga Ni-Cr-Mo-Ti.

\begin{tabular}{rcccccccc}
\hline & $\mathrm{Ni}$ & $\mathrm{Cr}$ & $\mathrm{Mo}$ & $\mathrm{Ti}$ & $\mathrm{Al}$ & $\mathrm{Fe}$ & $\mathrm{Ca}$ & $\mathrm{Cu}$ \\
\hline FAAS & 76,66 & 10,04 & 6,97 & 1,10 & 4,46 & 0,024 & $<0,01$ & $<0,01$ \\
nominal & 60 a 76 & 12 a 21 & 4 a 14 & 4 a 6 & - & - & - & - \\
\hline
\end{tabular}




\subsubsection{Meios de ensaio}

a) Cloreto de sódio $9 \mathrm{~g} \mathrm{~L}^{-1}\left(0,15 \mathrm{~mol} \mathrm{~L}^{-1}\right)$, para simular o efeito do soro fisiológico presente na saliva. Obtido da solubilização de $\mathrm{NaCl}$ P.A. com pureza mínima de 99,0\%, da Casa Americana (Brasil). A solução, obtida com água bidestilada naturalmente aerada, apresentou $\mathrm{pH}=6,4$.

b) Ácido cítrico, $\mathrm{HOOC}-\mathrm{CH}_{2}-\mathrm{C}(\mathrm{OH})(\mathrm{COOH})-\mathrm{CH}_{2}-\mathrm{COOH}$, ou ácido 2-hidróxipropano1,2,3-tricarboxílico, a $11 \mathrm{~g} \mathrm{~L}^{-1}\left(0,057 \mathrm{~mol} \mathrm{~L}^{-1}\right)$ em $\mathrm{NaCl} 9 \mathrm{~g} \mathrm{~L}^{-1}$, representado como $\mathrm{H}_{3} \mathrm{Cit}$, para simular o efeito do suco de laranja [17]. Obtido da solubilização de ácido cítrico monoidratado P.A., da Casa Americana (Brasil). A solução obtida com água bidestilada apresentou $\mathrm{pH}=2,1$.

c) Fluoreto de sódio 3,3 $\mathrm{g} \mathrm{L}^{-1}\left(0,079 \mathrm{~mol} \mathrm{~L}^{-1}\right)$, em NaCl $9 \mathrm{~g} \mathrm{~L}^{-1}$, para simular 0 conteúdo de ín fluoreto, 0,15\%m, presente em alguns dentifrícios bucais. Obtido da solubilização de NaF P.A., da Casa Americana (Brasil). A solução obtida com água bidestilada apresentou $\mathrm{pH}=7,2$.

d) Albumina de soro bovino (Bovine Serum Albumin - BSA), pI=5,5 [18], adicionada nos meios (a) a (c), a $0,20 \mathrm{~g} \mathrm{~L}^{-1}$, concentração que mostrou influenciar resultados eletroquímicos realizados em saliva artificial por outros pesquisadores (Huang [11]), obtida da solubilização de albumina bovina com pureza mínima 98\%, da Sigma (Brasil), código A-7030. 


\subsubsection{Materiais de embutimento}

Foram usados o teflon e três variedades de resinas, duas epóxi e uma epóxi-vinil-éster, ou EVER, com características destacadas na tabela 3.

Tabela 3 - Características das três resinas usadas para embutimento de eletrodos de trabalho.

\begin{tabular}{|c|c|c|c|}
\hline Nome comercial & Epofix & Araldite & Derakane 470 \\
\hline Tipos de resinas & epóxi & epóxi & epóxi-vinil-éster \\
\hline $\begin{array}{r}\text { Composições fornecidas } \\
\text { pelos fabricantes }\end{array}$ & $\begin{array}{l}\text { epicloridrina- } \\
\text { bisfenol-A }\end{array}$ & indisponível & $\begin{array}{c}\text { novolaca epoxidisada- } \\
\text { vinil-éster }\end{array}$ \\
\hline Endurecedores & trietilenotetramina ${ }^{\#}$ & poliaminoamidas & $\mathrm{NafCo}^{*} / \mathrm{MEKP}^{* *} / \mathrm{DEA}^{* * *}$ \\
\hline Fabricantes & $\begin{array}{l}\text { Struers S.A. } \\
\text { (Dinamarca) }\end{array}$ & $\begin{array}{l}\text { Vantico Ltda. } \\
\quad \text { (Brasil) }\end{array}$ & $\begin{array}{l}\text { Dow Química S.A. } \\
\text { /Ashland Inc.\$ (Brasil) }\end{array}$ \\
\hline
\end{tabular}

${ }^{\#} \mathrm{~N}, \mathrm{~N}$-bis(2-aminoetil)-etilenodiamina, *naftenato de cobalto, **peróxido de metil-etil-cetona,

***dietilanilina, ${ }^{\$}$ houve troca recente (2005) de fabricante

\subsection{Temperatura de estudo}

$(36,5 \pm 0,5){ }^{\circ} \mathrm{C}$

\subsection{Confecção de eletrodos de trabalho}

Foram obtidas amostras diversas dos quatro materiais metálicos escolhidos para ensaio, algumas em forma de cilindros e outras em forma de peças de uso em implantes e próteses dentais. Seu tratamento para gerar os eletrodos de trabalho seguiu dois procedimentos básicos, dependendo da processabilidade que cada material ofereceu:

a) para o embutimento em teflon, as amostras de dimensões apropriadas eram torneadas, a fim de adquirirem forma cilíndrica. Foram criados caminhos de rosca nas que possuíam altura e diâmetro permissíveis, sendo essas amostras posteriormente rosqueadas a hastes de latão. As que não puderam ser rosqueadas foram soldadas com solda $\mathrm{Pb}-\mathrm{Sn}$ às hastes de latão. Os conjuntos assim obtidos eram introduzidos, sob pressão e a quente, em cilindros vazados de teflon que, ao esfriarem, fechavam-se em torno do material metálico de estudo, gerando a vedação necessária para os ensaios eletroquímicos. 
b) para o embutimento em resina, optou-se pela fixação da amostra metálica, por solda, a fios de cobre ou hastes de latão, ou fixação sob pressão, em depressões criadas em hastes de latão, e introdução do conjunto em moldes onde se entornavam resinas líquidas que eram, em seguida, curadas.

No caso particular de embutimento na resina Derakane, houve a necessidade de tratamento térmico de pós-cura em estufa, descrito pelo fabricante como necessário para obter propriedades químicas e mecânicas máximas da resina, bem como minimizar seu teor residual de estireno. A tabela 4 traz as relações entre temperatura e tempo de cura. Neste trabalho foi adotada a temperatura de $80{ }^{\circ} \mathrm{C}$.

Tabela 4 - Relação entre tempos de pós-cura e temperatura para a resina Derakane.

\begin{tabular}{lccc}
\hline Temperatura $/{ }^{\circ} \mathrm{C}$ & 70 & 80 & 95 \\
Tempo $/ \mathrm{h}$ & 16 a 20 & 4 a 8 & 2 a 4 \\
\hline
\end{tabular}

Para fabricação dos eletrodos de amálgama de prata, embutia-se primeiramente o fio de cobre ou a haste de latão na resina e, após sua cura, a resina era perfurada até atingir o cobre ou o latão, gerando um canal por onde se introduzia a amálgama recém-preparada, na forma pastosa (plástica), como a uma cavidade dental, fazendo contato com o metal da haste. Tal procedimento distinto para a amálgama tentou simular a forma como a mesma é introduzida pelo dentista na boca de um paciente. Após $24 \mathrm{~h}$ de espera (período de cristalização da mistura), fazia-se o lixamento da face de ensaio. Testes posteriores mostraram que os eletrodos assim obtidos sofriam infiltração das soluções de ensaio na interface metal-resina, talvez pelo fato de, durante o processo de cristalização da amálgama, haver a formação de frestas na mencionada interface. 0 problema parece ter sido sanado pelo reembutimento da amálgama já cristalizada em novo molde resinoso. Na figura 13, pode-se observar de forma qualitativa o comportamento eletroquímico do eletrodo com amálgama (já cristalizada) reembutida na resina (curva a), contra o que teve a amálgama introduzida antes de sua cristalização (curva b). 


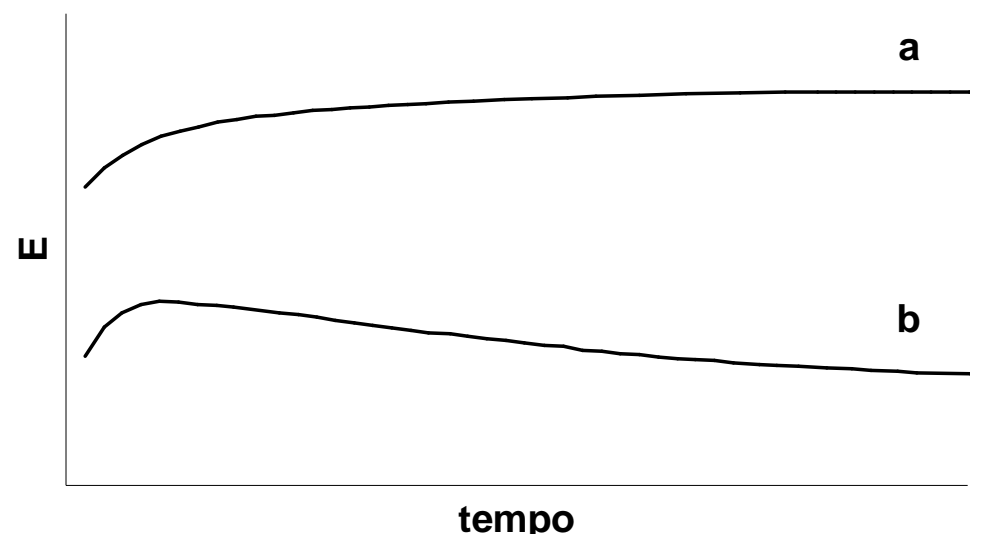

Figura 13. Comparação de curvas de potencial de circuito aberto estacionário de eletrodos com amálgama de prata já cristalizada e reembutida (a) contra amálgama que sofreu cristalização no interior da resina de embutimento (b), caso este em que ocorreu infiltração de meio de ensaio na interface metal-resina, alterando o comportamento eletroquímico.

As resinas, depois de curadas, eram então lixadas com lixa d'água de 200 a 350 mesh, até expor a face metálica para contato com os meios de ensaio, e polidas com lixa de 600 mesh ou 1500 mesh (figura 14).

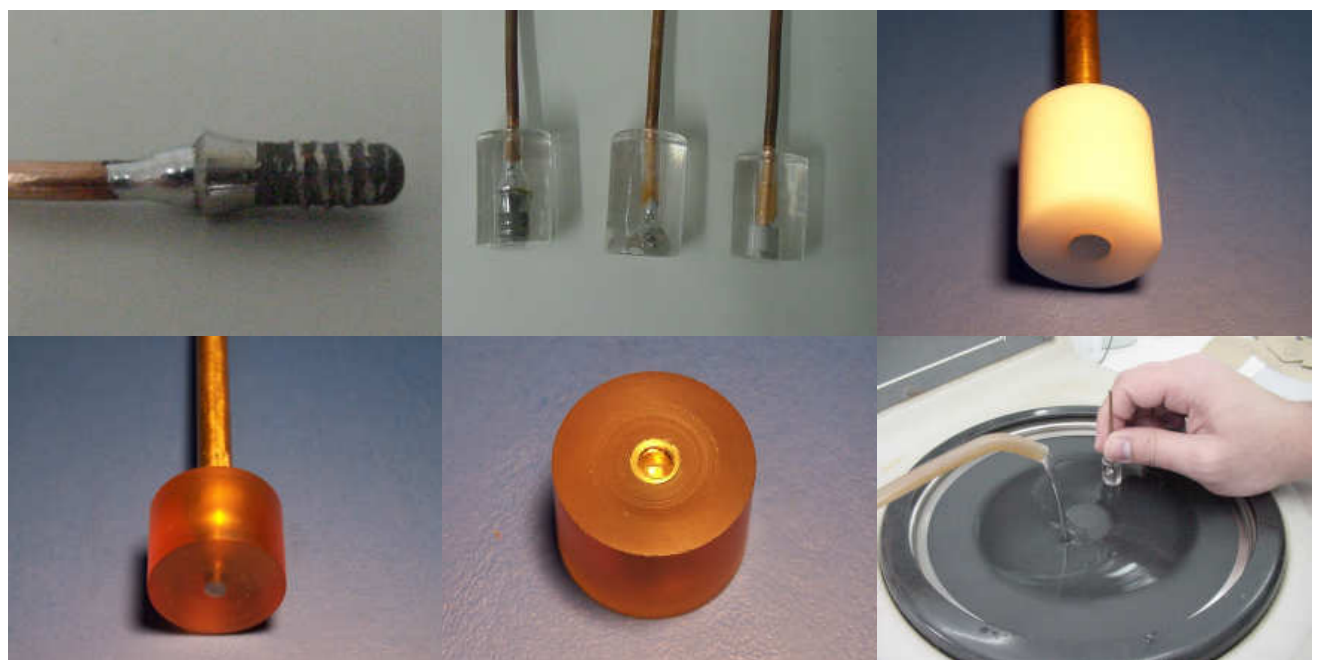

Figura 14. Da esquerda para a direita, de cima para baixo: (1) implante de Ti-cp soldado a fio de $\mathrm{Cu}$; (2) duas amostras Ti-cp - uma como parafuso e outra como porca - e uma de amálgama de Ag-Sn-Cu-Zn, embutidas em epofix com fio de cobre; (3) amostra de liga Ni-Cr-Mo-Ti embutida em teflon com haste de latão; (4) amostra de Ticp embutida em derakane com haste de latão; (5) detalhe de embutimento em derakane com destaque ao lado oposto em que se encontra a amostra metálica de ensaio de liga Au-Pt-Pd (observa-se no centro o corte da haste de latão feito para fixação da haste); (6) eletrodo sendo lixado em politriz elétrica. 


\subsection{Técnicas empregadas}

\subsubsection{Potencial de circuito aberto estacionário}

A face metálica de interesse de cada eletrodo de trabalho era polida com lixa d'água apropriada para a dureza de cada material: 600 mesh para a liga Ni-Cr-Mo-Ti e o Ti-cp, e 1500 mesh para a ligas Au-Pt-Pd e amálgama de Ag-Sn-Cu-Zn. Em seguida, essa superfície polida era lavada com água bidestilada, álcool comercial $96{ }^{\circ} \mathrm{GL}$ e novamente com água bidestilada, secada com secador elétrico de ar quente e posta em contato com $50 \mathrm{~mL}$ de solução de ensaio contida em béquer de $100 \mathrm{~mL}$, imerso, por sua vez, em banho termostatizado (Fisatom modelo 557) a $(36,5 \pm 0,5){ }^{\circ} \mathrm{C}$. No mesmo béquer, inseriu-se um eletrodo de referência (adotou-se o eletrodo de calomelano saturado: ECS), e os dois eletrodos - de trabalho e de referência - eram ligados a um multímetro. Foi monitorado o potencial do eletrodo de trabalho contra o de referência, de 1 em 1 minuto, nos 5 minutos iniciais, e de 5 em 5 minutos, no tempo restante, até que $o$ sistema atingisse o estado estacionário, tendo sido adotado como critério de estabilidade variação não superior a $1 \mathrm{mV}$ por 10 ou 15 minutos consecutivos, dependendo da amostra metálica ensaiada. A partir das curvas geradas em diversas medidas, extraiu-se o potencial de corrosão ( $\left.E_{\text {corr }}\right)$ de cada eletrodo de trabalho, entendendo-se este potencial como sendo o de circuito aberto estacionário ou quase estacionário atingido pelo eletrodo em cada meio de ensaio. Os resultados eram registrados num gráfico de potencial em função do tempo.

No capítulo 3, será revelado que a liga Ni-Cr-Mo-Ti mostrou-se polifásica, com composição superficial e propriedades eletroquímicas alteradas a cada polimento para novo ensaio. Essa característica impedia a comparação entre meios de ensaio diferentes em relação ao branco $\left(\mathrm{NaCl} 9 \mathrm{~g} . \mathrm{L}^{-1}\right)$, já que, entre cada experimento, era feito um polimento da superfície do eletrodo. Para contornar essa dificuldade, adotou-se o seguinte procedimento, cujas etapas podem ser acompanhadas na figura 15: (a) determinava-se $\circ \mathrm{E}_{\mathrm{corr}}$ pela forma descrita no parágrafo anterior, mas em $45 \mathrm{~mL}$ de solução do branco, em lugar de $50 \mathrm{~mL}$; (b) sem remoção do eletrodo de trabalho do meio, fazia-se a polarização anódica da superfície, que será descrita em 2.4.2; (c) esperava-se o sistema 
atingir novamente o $\mathrm{E}_{\text {corr; }}$ (d) promovia-se nova polarização do eletrodo; (e) esperava-se até a obtenção de $E_{\text {corri }}(f)$ efetuava-se nova polarização do eletrodo; (g) adicionavam-se ao branco, com agitação, $5 \mathrm{~mL}$ de solução de $\mathrm{NaF}, \mathrm{H}_{3} \mathrm{Cit}$ ou BSA, com concentração dez vezes maior que a determinada para estudo, descrita

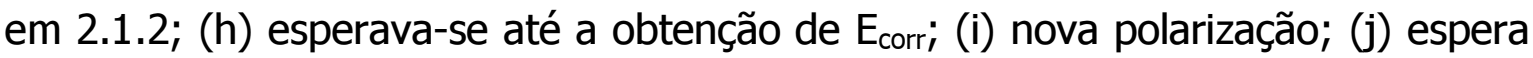
para obtenção de $E_{\text {corr; }}(k)$ nova polarização; ( $\left.\mathrm{l}\right)$ espera para obtenção de $E_{\text {corr; }}(\mathrm{m})$ nova polarização; (n) adição com agitação, nos casos em que ainda não foi introduzida a proteína, de $5 \mathrm{~mL}$ de BSA dez vezes mais concentrada que o descrito em 2.1.2; (o) espera para obtenção de $E_{\text {corri }}(p)$ nova polarização; $(q)$ espera para obtenção de $E_{\text {corri }}(r)$ nova polarização; (s) espera para obtenção de $E_{\text {corr; }}(t)$ nova polarização.

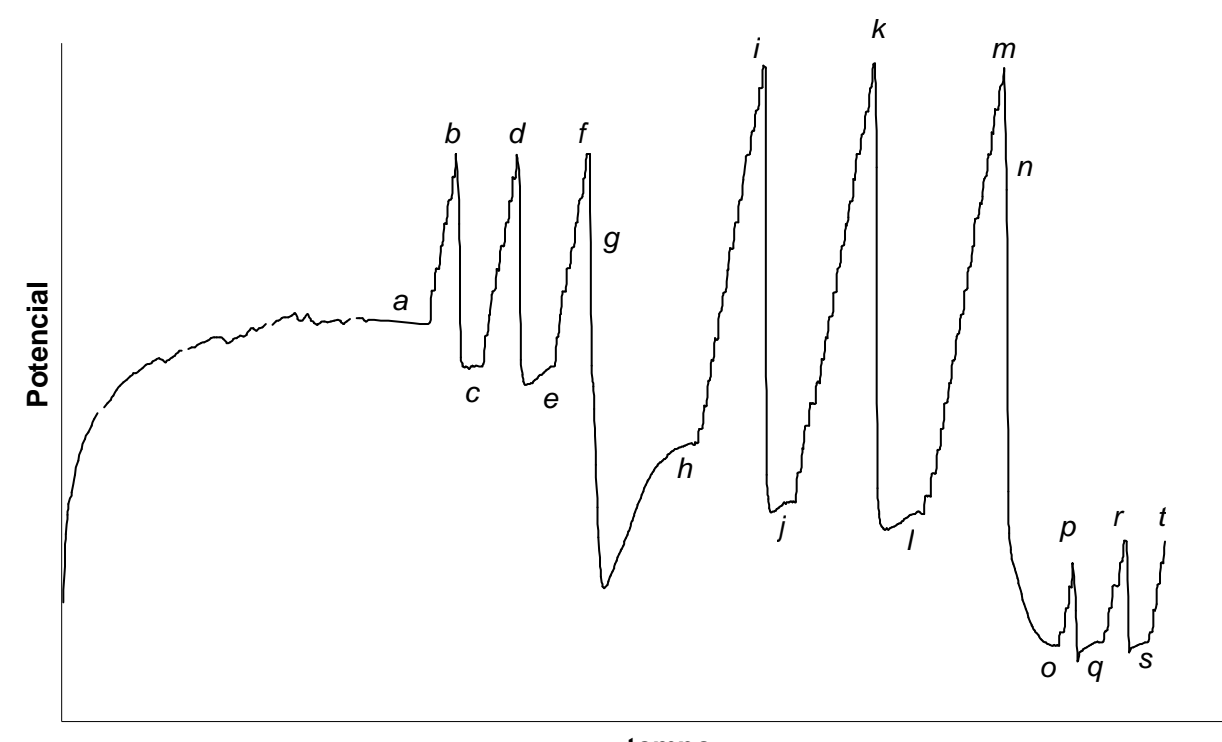

tempo

Figura 15. Gráfico mostrando potencial do eletrodo de trabalho versus ECS em função do tempo.

Mantendo-se, durante todo o processo, o monitoramento dos potenciais do eletrodo de trabalho em relação ao de referência, por meio de um multímetro interfaciado a um computador de mesa, puderam-se obter gráficos de potencial em função do tempo semelhantes ao da figura 15. Esse exemplo retrata o estudo da influência da adição de solução de NaF no branco e da adição de BSA ao branco contendo NaF. Dos trechos (a), (c) e (e), pode-se extrair triplicata de $\mathrm{E}_{\text {corr }}$ do branco; de (h), (j) e (I) obtém-se triplicata de $E_{\text {corr }}$ do branco com NaF; e (o), (q) e (s) fornecem a triplicata de $\mathrm{E}_{\text {corr }}$ de BSA no branco contendo NaF. 
Esse procedimento aceita que facilmente se compare, mesmo numa avaliação qualitativa, o efeito da adição de certo soluto ao meio anterior, além de permitir a manutenção de uma mesma superfície do eletrodo e a obtenção, num mesmo dia, desses resultados e dos resultados extraídos das polarizações.

Como essa metodologia foi introduzida para avaliação da liga $\mathrm{Ni}-\mathrm{Cr}-\mathrm{Mo}-\mathrm{Ti}$, com bons resultados, decidiu-se estendê-la também para ensaios que tinham que ser refeitos com os outros materiais metálicos de estudo, à exceção do Ti-cp, que já apresentava um bom número de resultados satisfatórios pelo procedimento convencional, os quais foram mantidos.

\subsubsection{Polarização potenciostática anódica}

Uma vez atingido o potencial de corrosão, fazia-se a polarização potenciostática anódica do eletrodo de trabalho, adicionando-se ao béquer um contra-eletrodo de platina, de área muito maior que a do eletrodo de trabalho, e ligando-se o sistema todo a um potenciostato (Aardvark/USA modelo PEC-1, zero a $2,0 \mathrm{~V}$ ), de forma a gerar potenciais positivos crescentes no eletrodo de trabalho, em relação ao eletrodo de referência (figura 16). O voltímetro V1 monitorava os potenciais aplicados entre o eletrodo de trabalho (ET) e o eletrodo de referência (ER), de calomelano saturado. A cada incremento positivo de potencial aplicado ao eletrodo de trabalho, verificava-se o valor da densidade de corrente estacionária ( $\boldsymbol{i}$ constante com o tempo) presente entre o eletrodo de trabalho e o contra-eletrodo, pela conversão dos valores de potenciais lidos em V2, através da equação $\boldsymbol{i}=\boldsymbol{E} /(\boldsymbol{R} . \boldsymbol{A})$, sendo A a área geométrica da superfície metálica de ensaio e R um resistor padrão de $98,2 \Omega$. Essa resistência deve ser da ordem de $10^{2} \Omega$ para que seja suficientemente menor do que a resistência entre o eletrodo de trabalho e o contra eletrodo, superior a $1 \mathrm{k} \Omega$. Os resultados eram registrados em um gráfico de densidade de corrente em função do potencial aplicado ( $\left.E_{a p l}\right)$. Os ET eram polarizados até se observar deflecção na curva de densidade de corrente versus potencial, indicativa de início de rompimento de filme passivo ou de outro processo faradaico gerador de subida de corrente. 


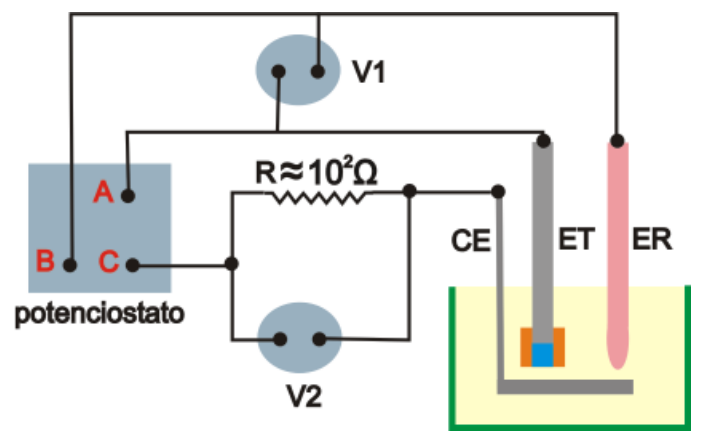

Figura 16. Esquema da montagem utilizada para ensaios de polarização potenciostática anódica.

\subsubsection{Microscopia Eletrônica de Varredura (MEV)}

As amostras eram polidas até lixa d'água 1200 mesh e depois com pasta de alumina de $1 \mu \mathrm{m}$ e 0,3 $\mu \mathrm{m}$, ou com pasta de diamante de 0,3 $\mu \mathrm{m}$ de diâmetro de grão, para deixar a superfície metálica reflexiva, e então examinadas em um microscópio eletrônico de varredura (Stereo Scan 440-LEICA acoplado a EDS, modelo ISIS Oxford - Inglaterra).

\subsubsection{Espectroscopia por Dispersão de Energia (EDS)}

Detectores apropriados, descritos no item 2.4.3, acoplados ao microscópio eletrônico permitiam a obtenção de espectrogramas mostrando a composição qualitativa e semi-quantitativa dos elementos prováveis existentes numa dada superfície metálica estudada.

\subsubsection{Espectrometria de Absorção Atômica de Chama (FAAS)}

Essa técnica foi utilizada para determinar a composição quantitativa média das ligas Ni-Cr-Mo-Ti e Au-Pt-Pd. As amostras metálicas eram dissolvidas em mistura apropriada de ácidos e a solução obtida diluída e levada ao espectrômetro de chama (Espectrômetro Seqüencial Varian AA220 FS).

\subsubsection{Espectroscopia de Impedância Eletroquímica (EIE)}

Utilizou-se, nos ensaios de EIE, um analisador de freqüências PAR modelo 1025 acoplado a um potenciostato PAR modelo 273A. O intervalo de freqüências empregado foi entre $12,3 \mathrm{kHz}$ e $3,51 \mathrm{mHz}$ e a amplitude de variação de potencial foi de $\pm 10 \mathrm{mV}$ em torno do potencial de corrosão ( $\left.E_{\text {corr }}\right)$. 
Capítulo 3: Resultados com Discussão 


\subsection{Desempenho dos materiais de embutimento}

\subsubsection{Avaliação do desempenho}

Foram adotados os seguintes critérios para a avaliação dos materiais de embutimento utilizados: (I) limitações apresentadas no seu uso para confecção de eletrodos de trabalho; (II) sua inércia química, refletida em mudança das propriedades mecânicas e visuais e nos resultados obtidos dos ensaios eletroquímicos.

\section{Dificuldades encontradas na construção dos eletrodos}

\section{- Eletrodos de titânio comercialmente puro}

As amostras de Ti-cp - as quais vinham na forma de parafusos - para embutimento em teflon, tinham que ser torneadas até a geometria cilíndrica, adquirindo diâmetro final bastante reduzido, de 3 a $5 \mathrm{~mm}$, o que parece ter prejudicado a vedação, já que houve infiltração do meio de ensaio entre o metal e o teflon. Como o embutimento em resina, da forma como foi descrito no item 2.3, permite que o polímero se adapte ao formato externo da amostra metálica, esperava-se obter eletrodos com boa vedação a partir do recobrimento dos parafusos de Ti-cp, sem a necessidade de torneamento para eliminar os passos da rosca. Verificou-se, entretanto, que surgiam microfrestas na interface com o polímero à medida que esses eletrodos eram desbastados pelo lixamento, devido aos sulcos dos passos de hélice. Foi necessário, portanto, o torneamento dos parafusos até a forma cilíndrica para obtenção de eletrodos adequados aos ensaios de imersão.

\section{- Eletrodos de liga Au-Pt-Pd}

No caso das primeiras amostras de liga áurica embutidas em teflon, o contato do material de ensaio com a haste de latão foi feito por solda $\mathrm{Pb}-\mathrm{Sn}$, já que as dimensões da amostra não permitiam o contato por rosqueamento. Após o 
uso de mais da metade da amostra (a qual era desgastada por lixamento antes de cada novo ensaio), o eletrodo obtido começou a apresentar potenciais de corrosão muito mais negativos do que os iniciais, e se constatou que, devido à alta temperatura usada durante o processo de inserção do conjunto amostra-latão no cilindro de teflon, ocorreu fusão parcial da solda de contato, a qual se difundiu por toda a lateral da amostra metálica, inclusive dissolvendo-se na liga áurica e alterando suas propriedades eletroquímicas. Tal fato pode ser verificado na figura 17, em que curvas de potencial de circuito aberto com embutimento em teflon são comparadas a outras com embutimento em epofix e derakane, em $\mathrm{NaCl}$ $9 \mathrm{~g} \mathrm{~L}^{-1}$. Observa-se que as curvas de epofix e de derakane apresentam um potencial estacionário ( $\left.E_{\text {corr }}\right)$ bem mais positivo do que as curvas de teflon. Esses valores tão mais negativos de potencial de corrosão para o embutimento em teflon são reflexo do efeito da contaminação por solda, que tornou menos nobre a superfície. Ainda na figura 17, as curvas designadas derakane mostram o efeito do embutimento com essa resina: os potenciais são elevados, de acordo com a nobreza da liga, e são reprodutíveis em todo o intervalo de tempo.

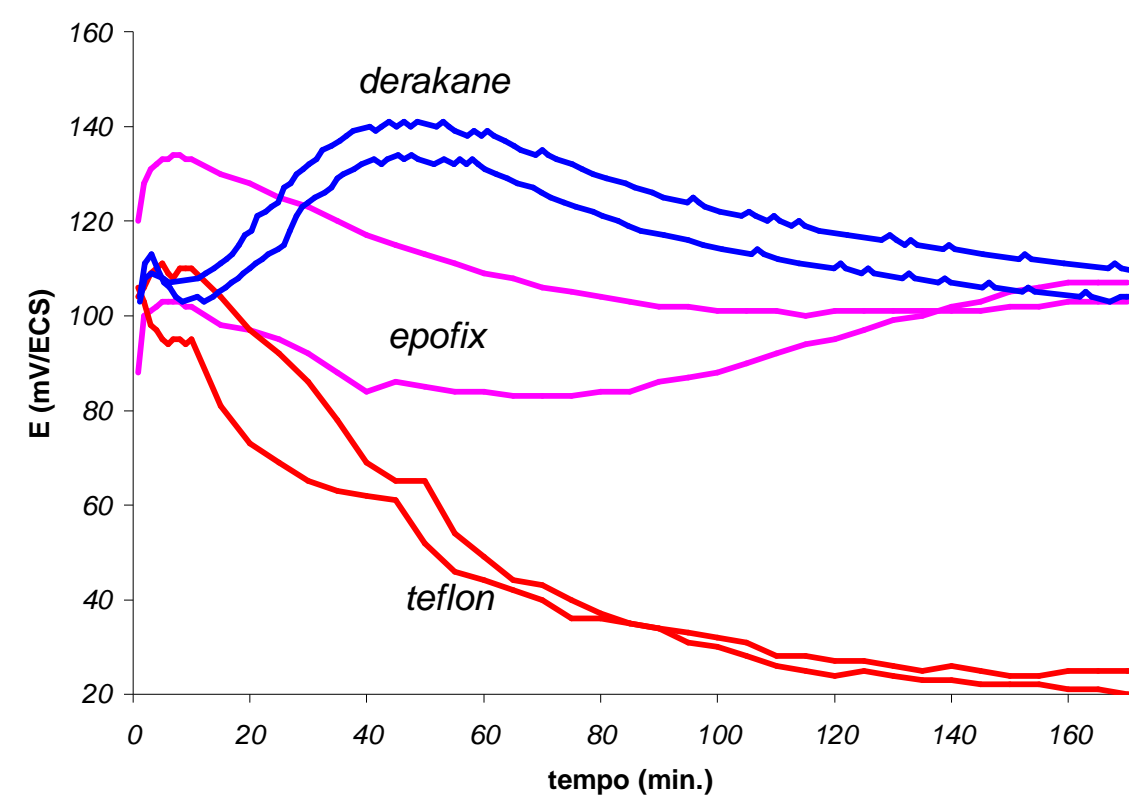

Figura 17. Curvas de potencial de circuito aberto de liga Au-Pt-Pd embutida em derakane, epofix e teflon, em $\mathrm{NaCl}$ fisiológico a $36,5{ }^{0} \mathrm{C}$. 


\section{II.Características dos eletrodos versus material de embutimento.}

\section{- Teflon}

Eletrodos de embutimento em resina mostraram-se mais resistentes que os embutidos em teflon, já que os últimos, se sofressem qualquer tipo de impacto, como uma queda, por exemplo, poderiam ter a vedação prejudicada, ocasionando infiltração quando imersos nos meios de ensaio.

No embutimento em teflon, como a amostra metálica é inserida sob pressão no interior do polímero, gerando uma vedação apenas mecânica, não é possível que se possa levar o eletrodo assim obtido para uma análise de MEV, devido às condições de vácuo a que se submete a amostra de ensaio, problema que não se verifica no embutimento em resina, de vedação mais eficiente dada a natureza de sua construção.

O embutimento em teflon é mais resistente ao lixamento que se faz para renovar a superfície metálica de ensaio a cada análise eletroquímica, e possui o inconveniente de diminuir muito rapidamente o tempo de vida das lixas, que têm seus poros obstruídos pelos fragmentos de polímero gerados no processo.

Há que se mencionar ainda que o comércio disponibiliza cilindros de teflon tanto na forma de maior pureza (chamado teflon virgem) quanto misturado a outros materiais denominados cargas, usados para diminuir seu custo e obter certa alteração nas propriedades mecânicas e térmicas, o que deve ser útil em determinadas aplicações. Infelizmente, nem sempre essa informação é disponibilizada, e um pesquisador que faça um pedido desse polímero pode adquirir, sem ser informado pelo fornecedor, o material com carga, inapropriado para a confecção de eletrodos sólidos para ensaios eletroquímicos.

\section{- Resinas}

Quanto às três variedades de resinas utilizadas: epofix, araldite e derakane, todas apresentaram boa vedação, resistência mecânica adequada, facilidade de lixamento e de adaptação a qualquer formato de amostra metálica de ensaio. 
As duas resinas epóxi usadas - epofix e araldite - sofreram ataque pelo ácido cítrico empregado nos ensaios, o que pôde ser constatado visualmente, já que as resinas atacadas ficavam inchadas, elásticas a ponto de cederem à pressão dos dedos, com aparência esponjosa, às vezes apresentando mudança de cor e, em casos de ataque extremo, chegavam a se rasgar e descolar se tensionadas manualmente. Esse inconveniente não foi observado nos casos de embutimento em derakane, confirmando a inércia química apontada pelo fabricante como ponto forte desse polímero, que foi desenvolvido com o fim de resistir a meios de $\mathrm{pH}$ agressivos, tanto ácidos quanto básicos, e a solventes orgânicos.

Podem-se mencionar como inconvenientes da resina Derakane: (a) seu processo de moldagem exige três agentes de cura, enquanto as outras precisam de apenas um, e grande cuidado nas quantidades adicionadas de cada uma dessas substâncias à resina, sem o que não ocorre endurecimento; (b) necessita de tratamento térmico de pós-cura em estufa para obter propriedades químicas e mecânicas máximas da resina, bem como minimizar seu teor residual de estireno.

A tabela 5 resume as observações mais importantes a respeito de cada polímero de embutimento.

Tabela 5 - Comparação das características dos diferentes materiais de embutimento, observadas durante os experimentos. Destacadas, em azul, as características desejáveis e, em vermelho, as indesejáveis.

\begin{tabular}{|c|c|c|c|c|}
\hline & Teflon & Epofix & Araldite & Derakane \\
\hline $\begin{array}{l}\text { capacidade de adaptação ao formato da } \\
\text { amostra }\end{array}$ & não possui & possui & possui & possui \\
\hline aquecimento durante embutimento & necessita & não necessita & não necessita & não necessita \\
\hline resistência a choques mecânicos no manuseio & baixa & alta & alta & alta \\
\hline vedação apropriada para análises de MEV & não possui & possui & possui & possui \\
\hline $\begin{array}{l}\text { ocorrência de infiltração enquanto em bom } \\
\text { estado em amostra metálica cilíndrica }\end{array}$ & ocorreu & não ocorreu & não ocorreu & não ocorreu \\
\hline inércia química nos meios de estudo & alta & baixa & baixa & alta \\
\hline aquecimento de pós-cura & não necessita & não necessita & não necessita & necessita \\
\hline
\end{tabular}

Observando-se os resultados sintetizados na tabela 5 , nota-se que as resinas acumulam o maior número de características positivas para os ensaios específicos de amostras de materiais de uso odontológico, as quais apresentam 
formatos diversos e dimensões reduzidas. Para ensaios em amostras de dimensões maiores, que possam ser dispostas no formato cilíndrico, o teflon continua sendo uma das melhores opções, dada a sua inquestionável inércia química, como a prática tem demonstrado. Como a inércia química é uma característica prioritária para análises de longo contato entre o eletrodo e o meio de ensaio, deve-se apontar, entre as resinas estudadas, derakane como a mais indicada para meios de pH agressivo, como é o caso de algumas das soluções estudadas neste trabalho.

\subsubsection{Interpretação dos resultados pela composição química}

Pode-se atribuir a excepcional inércia química do teflon a dois fatores: (a) a sua alta tensão superficial, que impede o contato íntimo da solução; (b) o fato de a energia da ligação C-F ser uma das mais altas entre as ligações simples, perdendo apenas para a ligação H-F: $485 \mathrm{~kJ} \cdot \mathrm{mol}^{-1}$ contra $567 \mathrm{~kJ} \cdot \mathrm{mol}^{-1}$, respectivamente (Brown et alii [19]).

Para se entenderem os motivos da maior inércia de derakane (resina do tipo epóxi-vinil-éster ou EVER) em relação às resinas araldite e epofix (epóxis tradicionais), faz-se necessário comparar suas estruturas (figura 18).

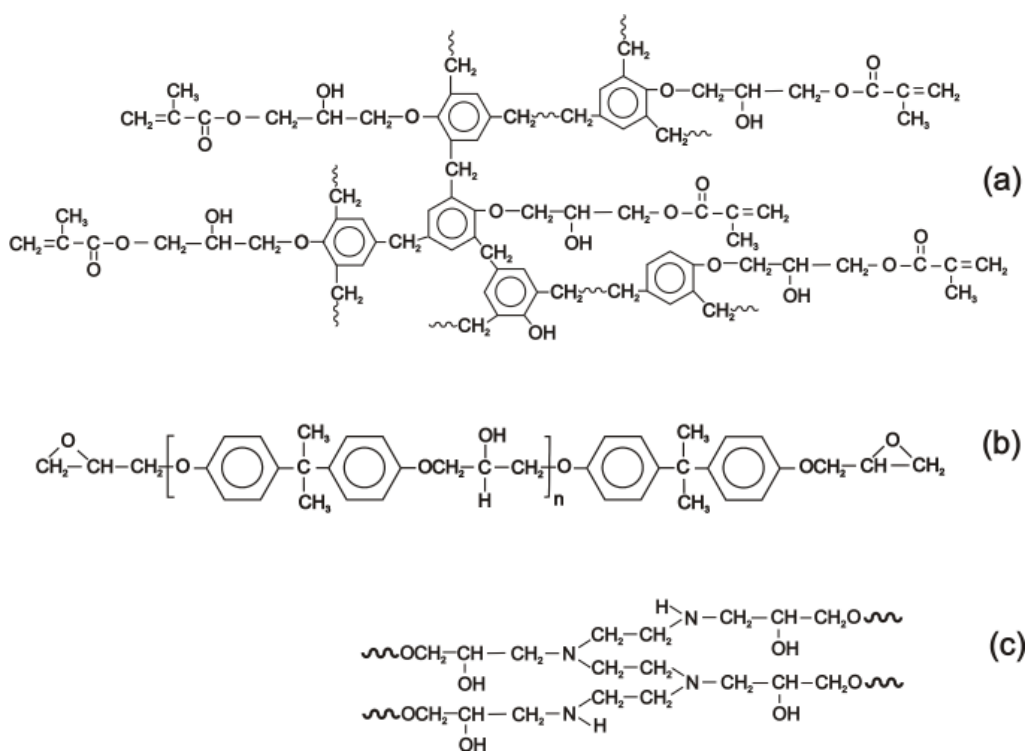

Figura 18. (a) Derakane 470 antes da cura final no molde, que ocorre pela reação dos grupos vinil com estireno; (b) resina epóxi antes da cura, que ocorre pela reação dos grupos epóxi com aminas polifuncionais; (c) resina epóxi curada pela reação dos grupos epóxi terminais com amina tetrafuncional. 
Já foi mencionado no item 1.6 que a cura da resina derakane utilizada neste trabalho, mostrada na figura 18 (a), dá-se pela reação dos grupos vinil com seu copolímero (e solvente) estireno, enquanto a cura das resinas epóxi se dá pela reação de aminas polifuncionais com os grupos epóxi terminais de moléculas como a da figura 18(b). Pode-se observar que o número de ligações cruzadas que cada molécula de derakane pode fazer é regido pelo número de anéis aromáticos da novolaca que a gerou, enquanto cada molécula de epóxi só possui dois extremos de cadeia para fazer ligações cruzadas e, mesmo obtendo uma estrutura mais complexa pela reação com uma tetramina, como em 18(c), o número de ligações cruzadas não se compara com a de derakane. Essa trama mais densa de ligações cruzadas em derakane explica o motivo da maior inércia química dessa EVER frente às epóxi tradicionais, já que o meio de ensaio ácido destrói a resina pela hidrólise de tais ligações. 


\subsection{Estudos eletroquímicos com a liga Au-Pt-Pd}

As figuras 19(a) e 19(b) mostram, respectivamente, a determinação do potencial de circuito aberto estacionário $\left(E_{\text {corr }}\right)$ e as curvas de polarização potenciostática anódica, para a liga Au-Pt-Pd em meio de cloreto de sódio $9 \mathrm{~g} \mathrm{~L}^{-1}$ (chamada de branco), e com 0,20 $\mathrm{g} \mathrm{L}^{-1}$ de albumina bovina adicionada a esse meio (branco+BSA).
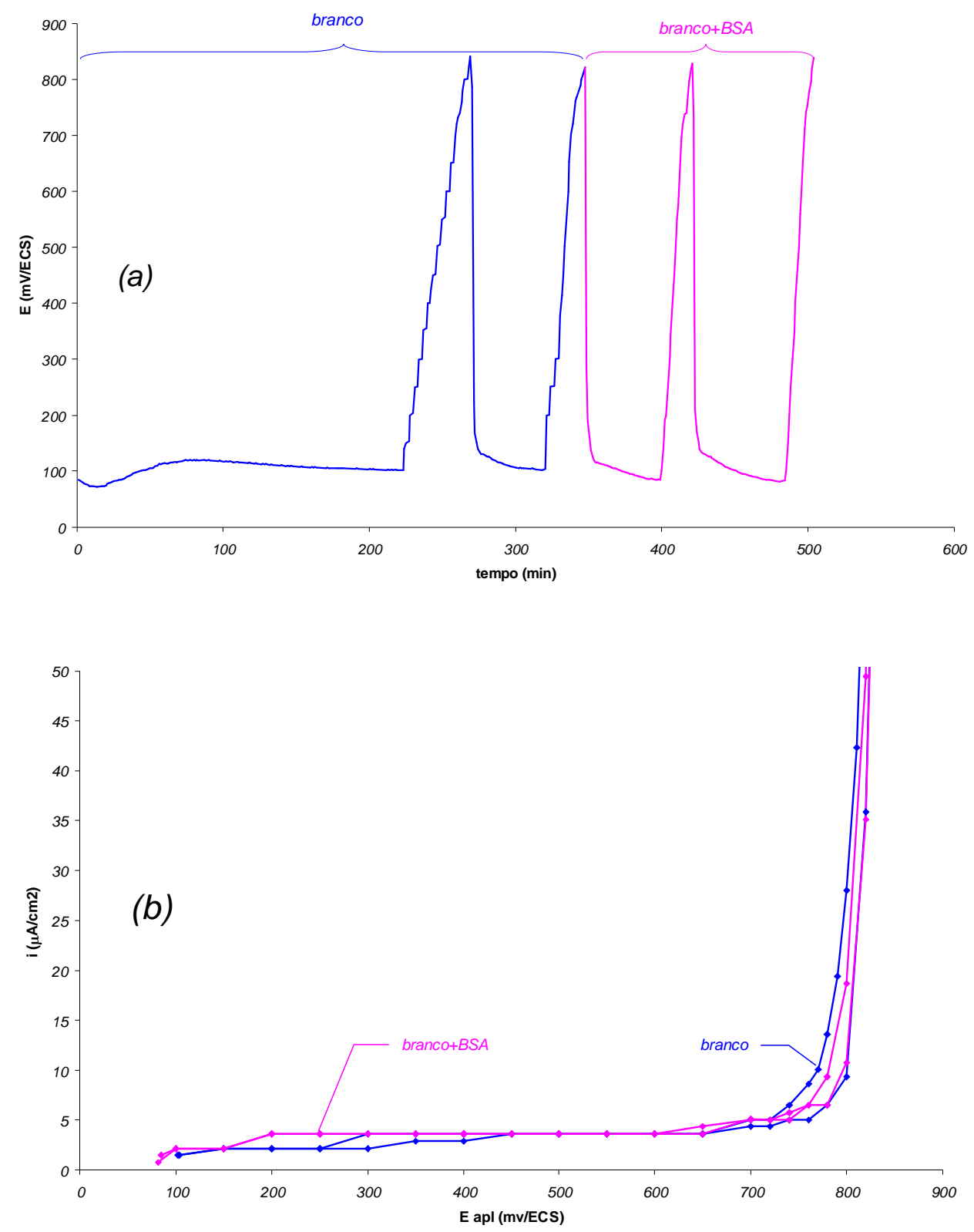

Figura 19. Determinação do potencial de circuito aberto estacionário ou $E_{\text {corr }}$ (a) e curvas de polarização potenciostática anódica (b) da liga Au-Pt-Pd, mostrando o efeito da adição de BSA ao branco. 
As figuras 20(a) e 20(b) mostram, respectivamente, a determinação do potencial de circuito aberto estacionário $\left(E_{\text {corr }}\right)$ e as curvas de polarização potenciostática anódica, para a liga Au-Pt-Pd em meio de cloreto de sódio $9 \mathrm{~g} \mathrm{~L}^{-1}$ (branco), fluoreto de sódio $3,3 \mathrm{~g} \mathrm{~L}^{-1}$ adicionado ao branco (branco+NaF), e albumina bovina $0,20 \mathrm{~g} \mathrm{~L}^{-1}$ adicionada ao branco+NaF (branco+NaF+BSA).
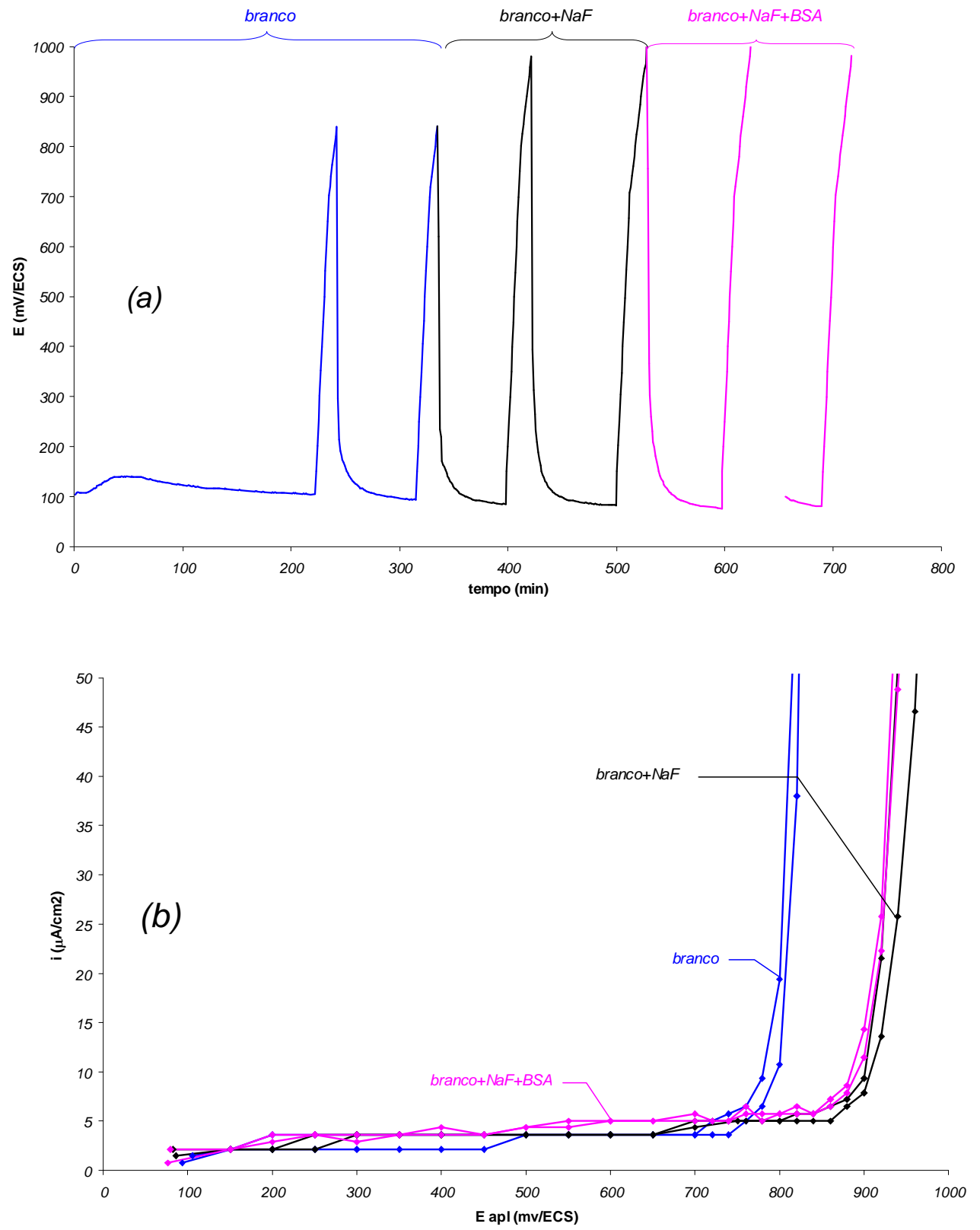

Figura 20. Determinação do potencial de circuito aberto estacionário ou $\mathrm{E}_{\text {corr }}$ (a) e curvas de polarização potenciostática anódica (b) da liga Au-Pt-Pd, mostrando o efeito da adição de $\mathrm{NaF}$ ao branco e de BSA ao branco+NaF. 
As figuras 21(a) e 21(b) mostram, respectivamente, a determinação do potencial de circuito aberto estacionário $\left(E_{\text {corr }}\right)$ e as curvas de polarização potenciostática anódica, para a liga Au-Pt-Pd em meio de cloreto de sódio $9 \mathrm{~g} \mathrm{~L}^{-1}$ (branco), ácido cítrico $11 \mathrm{~g} \mathrm{~L}^{-1}$ adicionado ao branco (branco $+\mathrm{H}_{3} \mathrm{Cit}$ ), e albumina bovina $0,20 \mathrm{~g} \mathrm{~L}^{-1}$ adicionada ao branco $+\mathrm{H}_{3} \mathrm{Cit}$ (branco $+\mathrm{H}_{3} \mathrm{Cit}+\mathrm{BSA}$ ).
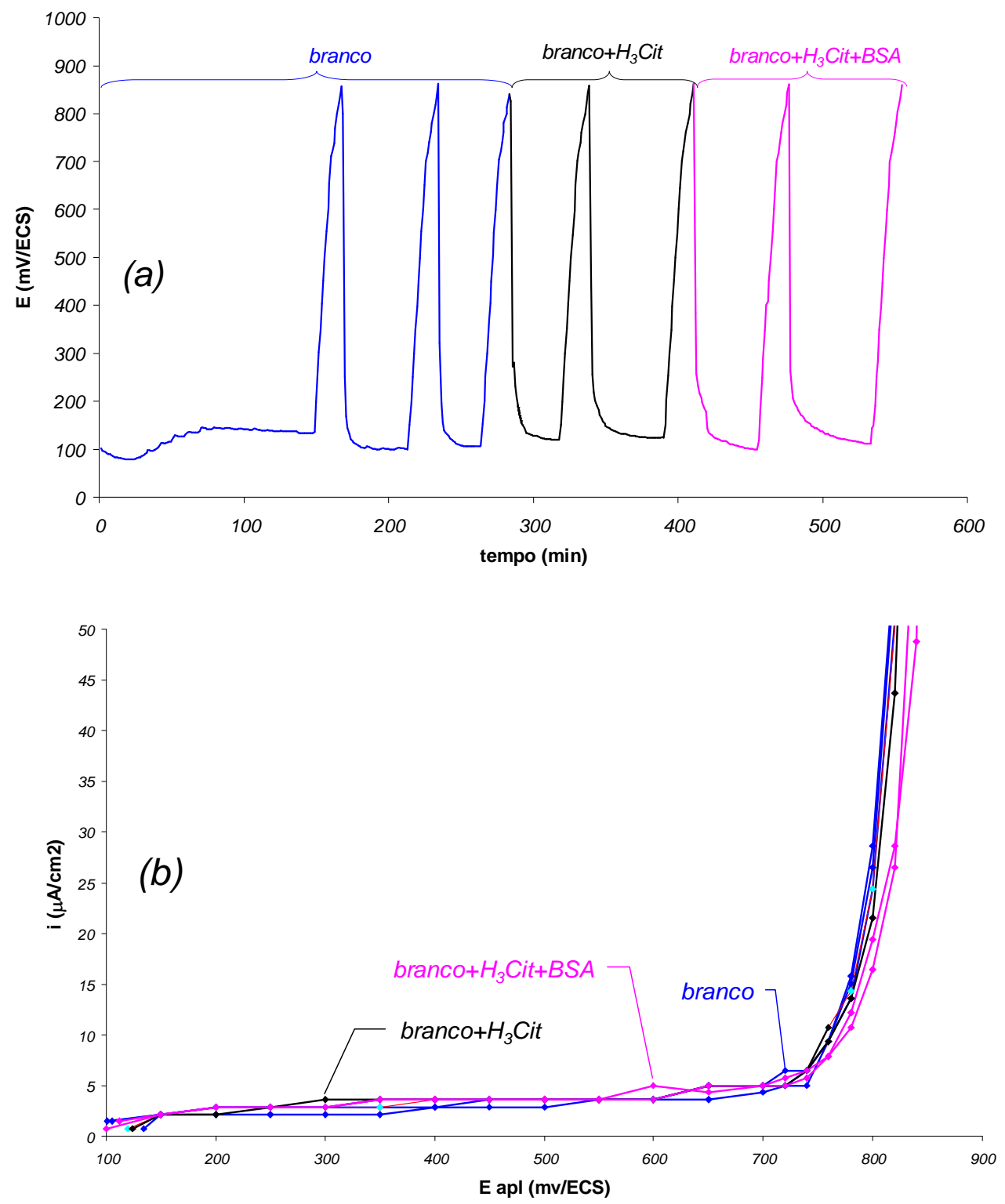

Figura 21. Determinação do potencial de circuito aberto estacionário ou $\mathrm{E}_{\text {corr }}$ (a) e curvas de polarização potenciostática anódica (b) da liga Au-Pt-Pd, mostrando o efeito da adição de $\mathrm{H}_{3} \mathrm{Cit}$ ao branco e de BSA ao branco+ $\mathrm{H}_{3} \mathrm{Cit}$. 
Na tabela 6, são apresentados os valores de potencial de corrosão ( $\left.E_{\text {corr }}\right)$, potencial de subida de corrente $\left(E_{s c}\right)$, faixa passiva (FP) e densidade de corrente de passivação (i pass $_{\text {ps }}$, para todos os meios estudados. A figura 22 destaca, em (a), os valores de $E_{\text {corr }} e$, em (b), os de $E_{s c}$, na forma de colunas, com barras representando os desvios-padrão.

Tabela 6 - Comparação dos parâmetros eletroquímicos obtidos nos diferentes meios estudados para liga Au-Pt-Pd. Entre parêntesis o número de ensaios realizados.

\begin{tabular}{|c|c|c|c|c|}
\hline meio & $E_{\text {corr }}(m V)$ & $E_{s c}(m V)$ & FP $(\mathrm{mV})$ & $i_{\text {pass }}\left(\mu A \mathrm{~cm}^{-2}\right)$ \\
\hline branco & $103 \pm 1(2)$ & $750 \pm 20(2)$ & $647 \pm 20(2)$ & $0 \pm 1$ a $4 \pm 1$ (2) \\
\hline branco+BSA & $84 \pm 1(2)$ & $770 \pm 10(2)$ & $686 \pm 10(2)$ & $0 \pm 1$ a $4 \pm 1(2)$ \\
\hline branco & $100 \pm 6(2)$ & $760 \pm 1(2)$ & $661 \pm 6(2)$ & $0 \pm 1$ a $4 \pm 1$ (2) \\
\hline branco+NaF & $84 \pm 2(2)$ & $880 \pm 1(2)$ & $797 \pm 2(2)$ & $0 \pm 1$ a $4 \pm 1(2)$ \\
\hline branco+NaF+BSA & $79 \pm 3(2)$ & $880 \pm 1(2)$ & $802 \pm 3(2)$ & $0 \pm 1$ a $4 \pm 1(2)$ \\
\hline branco & $104 \pm 4(2)$ & $740 \pm 1(3)$ & $626 \pm 16(3)$ & $0 \pm 1$ a $4 \pm 1(2)$ \\
\hline branco $+\mathrm{H}_{3} \mathrm{Cit}$ & $122 \pm 2(2)$ & $740 \pm 1(2)$ & $618 \pm 2(2)$ & $0 \pm 1$ a $4 \pm 1(2)$ \\
\hline Branco $+\mathrm{H}_{3} \mathrm{Cit}+\mathrm{BSA}$ & $106 \pm 6(2)$ & $740 \pm 1(2)$ & $634 \pm 6(2)$ & $0 \pm 1$ a $4 \pm 1(2)$ \\
\hline
\end{tabular}
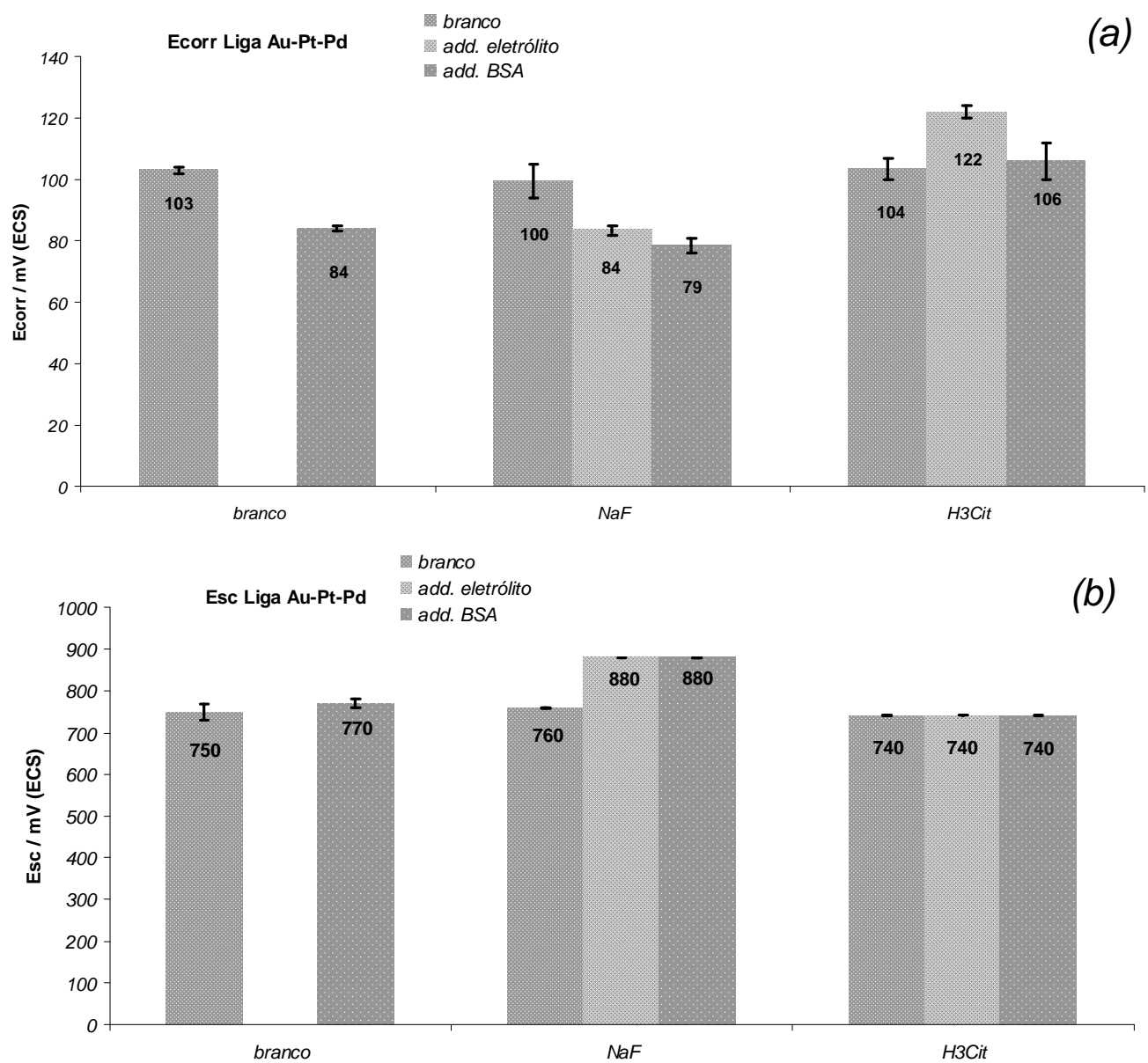

Figura 22. Valores de $\mathrm{E}_{\text {corr }}(\mathrm{a})$ e $\mathrm{E}_{\mathrm{sc}}$ (b) dos estudos realizados com a liga Au-Pt-Pd . 
É possível verificar, a partir da tabela 6, que a liga Au-Pt-Pd apresenta resultados bem reprodutíveis e uma faixa de potencial da ordem de $650 \mathrm{mV}$, em que se mantém passiva, em meio de $\mathrm{NaCl}$ (branco).

A adição de $\mathrm{NaF}$ ao branco torna mais negativos os potenciais de corrosão $\left(E_{\text {corr }}\right)$ da liga Au-Pt-Pd, de um valor da ordem de $20 \mathrm{mV}$; efeito maior é observado sobre o potencial de subida de corrente $\left(E_{s c}\right)$, que se torna $120 \mathrm{mV}$ mais positivo.

A adição de $\mathrm{H}_{3} \mathrm{Cit}$ ao branco exerce efeito contrário sobre o $\mathrm{E}_{\text {corr, }}$ tornandoo $20 \mathrm{mV}$ mais positivo, mas não altera o valor de $E_{s c}$. Conclui-se que a adição de ácido cítrico não afeta significativamente o comportamento da interfase estudada.

Pode-se observar que, à exceção do meio branco+NaF (onde não exerceu influência) a proteína tornou mais negativo, de apenas $10 \mathrm{mV}$ a $20 \mathrm{mV}$, o potencial de corrosão dos meios estudados. Nota-se também que a BSA não modificou, dentro do erro experimental, os valores de $E_{s c}$ em todos os meios testados. Estes resultados levam à conclusão de que, nos meios estudados, o efeito da albumina sobre o comportamento eletroquímico da liga Au-Pt-Pd não é significativo.

$O E_{s c}$ obtido para esse material no meio fisiológico $(\mathrm{pH}=7)$ foi de 0,75 V/ECS. Como o valor teórico de potencial de oxidação da água a oxigênio nesse $\mathrm{pH}$ vale $0,56 \mathrm{~V} / \mathrm{ECS}$, a subida de corrente poderia ser atribuída à reação $\mathrm{H}_{2} \mathrm{O} / \mathrm{O}_{2}$. No entanto, é preciso considerar dois aspectos quanto a essa hipótese:

$1^{0}$.) a sobretensão para a referida reação pode tornar, por motivos cinéticos, o valor de $E_{s c}$ bem mais elevado do que o esperado por cálculo termodinâmico, podendo ser superior, nesse caso, a 0,75 V/ECS;

$2^{\circ}$.) se a única reação que estivesse ocorrendo fosse

$$
\mathrm{H}_{2} \mathrm{O}(\mathrm{l}) \rightarrow 1 / 2 \mathrm{O}_{2}(\mathrm{~g})+2 \mathrm{H}^{+}(\mathrm{aq})+2 \mathrm{e}^{-}
$$

o valor de $E_{s c}$ deveria depender do $\mathrm{pH}$ da solução. Considerando o potencial de equilíbrio para a semi-reação acima apresentada, e admitindo que a ação catalítica do substrato seja a mesma, dever-se-ia esperar que os valores de $\mathrm{E}_{\mathrm{sc}}$ variassem na ordem: $E_{s c}($ branco $+N a F, p H \approx 7)<E_{s c}($ branco, $p H \approx 6)<E_{s c}\left(\right.$ branco $\left.+H_{3} C i t, p H \approx 2\right)$ 
Os resultados experimentais não correspondem a essa seqüência. Acreditase, portanto, que, no potencial de subida de corrente $\left(E_{s c}\right)$, mesmo que esteja ocorrendo a reação $\mathrm{H}_{2} \mathrm{O} / \mathrm{O}_{2}$, ocorram também, e em maior intensidade, processos de oxidação da liga neste potencial, que serão melhor interpretados a partir de exames por MEV e EDS da superfície da liga depois de submetida à polarização anódica a potenciais superiores a $\mathrm{E}_{\mathrm{sc}}$.

Tabelas de potenciais de redução padrão $\left(\mathrm{E}^{0}\right)$ mostram que os três metais - ouro, platina e paládio - apresentam, quando puros, valores de $E^{0}$ iguais a $1,15 \mathrm{~V}, 0,76 \mathrm{~V}$ e 0,62 V, respectivamente, na escala do hidrogênio e em meios de cloreto (Harris [20]). Na escala do calomelano saturado, esses valores passam a ser, respectivamente: 0,91 $\mathrm{V}$ para $\mathrm{AuCl}_{2}{ }^{1-} / \mathrm{Au}, 0,52 \mathrm{~V}$ para $\mathrm{PtCl}_{4}{ }^{2-} / \mathrm{Pt}, 0,38 \mathrm{~V}$ para $\mathrm{PdCl}_{6}{ }^{4} / \mathrm{Pd}$. É preciso que fique claro ser essa análise apenas qualitativa, por se tratar de uma liga.

Com o objetivo de mostrar o efeito do $\mathrm{pH}$ nos valores de $\mathrm{E}_{\mathrm{sc}}$ para a reação $\mathrm{H}_{2} \mathrm{O} / \mathrm{O}_{2}$, foram levantadas curvas de polarização anódica sobre eletrodos de grafite em meios de $\mathrm{NaCl} 9 \mathrm{~g} \mathrm{~L}^{-1}$ (branco) e de $\mathrm{NaCl} 9 \mathrm{~g} \mathrm{~L}^{-1}$ contendo $\mathrm{NaF} 3,3 \mathrm{~g} \mathrm{~L}^{-1}$ (branco+NaF). Na figura 23, observa-se qualitativamente o esperado sob o ponto de vista da termodinâmica: $\boldsymbol{E}_{s c}($ branco $+N a F, p H \approx 7)<E_{s c}($ branco, $p H \approx 6)$.

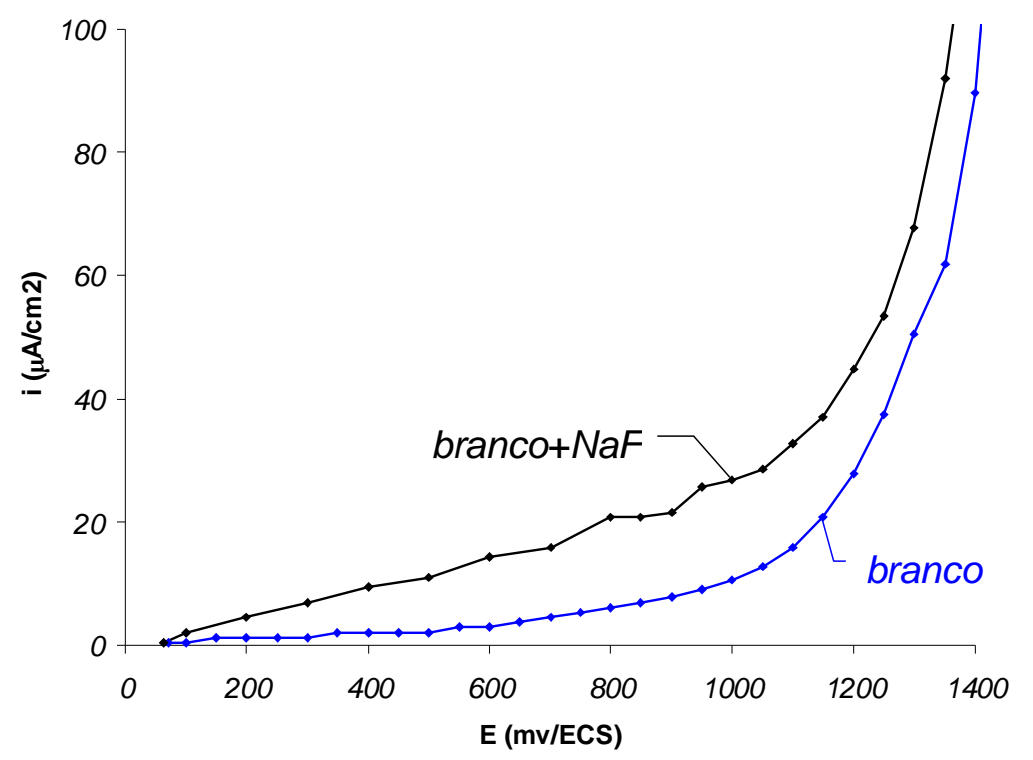

Figura 23. Curvas de polarização potenciostática anódica com ET de grafite, nos meios branco e branco+NaF. 
Quanto à ampliação da faixa passiva por adição de íons fluoreto, acreditase que esse íon, se adsorvido no eletrodo, esteja dificultando a oxidação dos metais na forma de complexos com cloreto.

\subsection{Estudos eletroquímicos com a Liga Ni-Cr-Mo-Ti}

As figuras 24(a) e 24(b) mostram, respectivamente, a determinação do potencial de circuito aberto estacionário $\left(E_{\text {corr }}\right)$ e as curvas de polarização potenciostática anódica, para a liga Ni-Cr-Mo-Ti em meio de cloreto de sódio $9 \mathrm{~g} \mathrm{~L}^{-1}$ (chamada de branco), e com 0,20 g L ${ }^{-1}$ de albumina bovina adicionada a esse meio (branco+BSA).
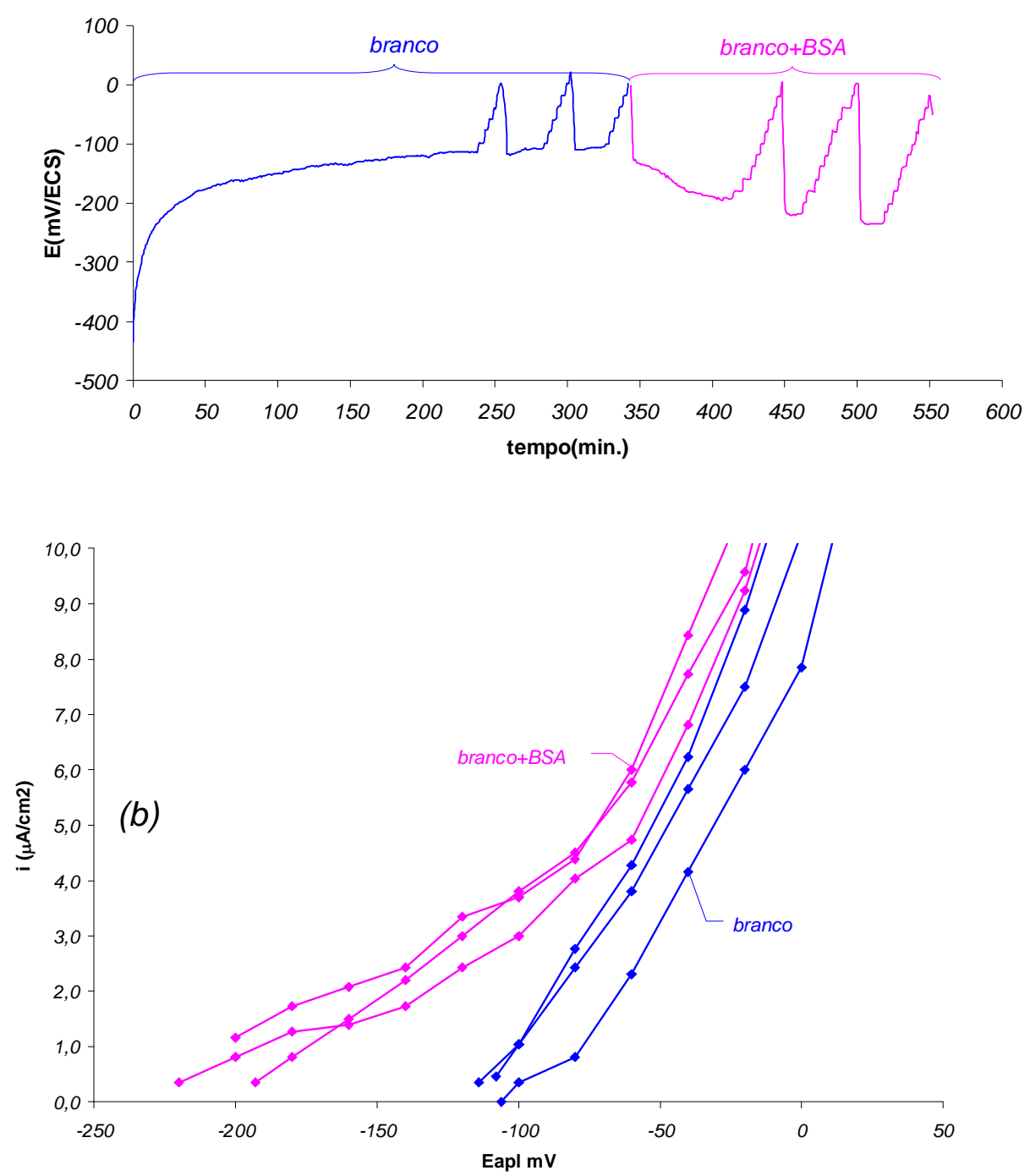

Figura 24. Determinação do potencial de circuito aberto estacionário ou $\mathrm{E}_{\text {corr }}$ (a) e curvas de polarização potenciostática anódica (b) da liga Ni-Cr-Mo-Ti, mostrando o efeito da adição de BSA ao branco. 
As figuras 25(a) e 25(b) mostram, respectivamente, a determinação do potencial de circuito aberto estacionário $\left(E_{\text {corr }}\right)$ e as curvas de polarização potenciostática anódica, para a liga Ni-Cr-Mo-Ti em meio de cloreto de sódio $9 \mathrm{~g} \mathrm{~L}^{-1}$ (branco), fluoreto de sódio 3,3 $\mathrm{g} \mathrm{L}^{-1}$ adicionado ao branco (branco+NaF), e albumina bovina $0,20 \mathrm{~g} \mathrm{~L}^{-1}$ adicionada ao branco+NaF (branco+NaF+BSA).
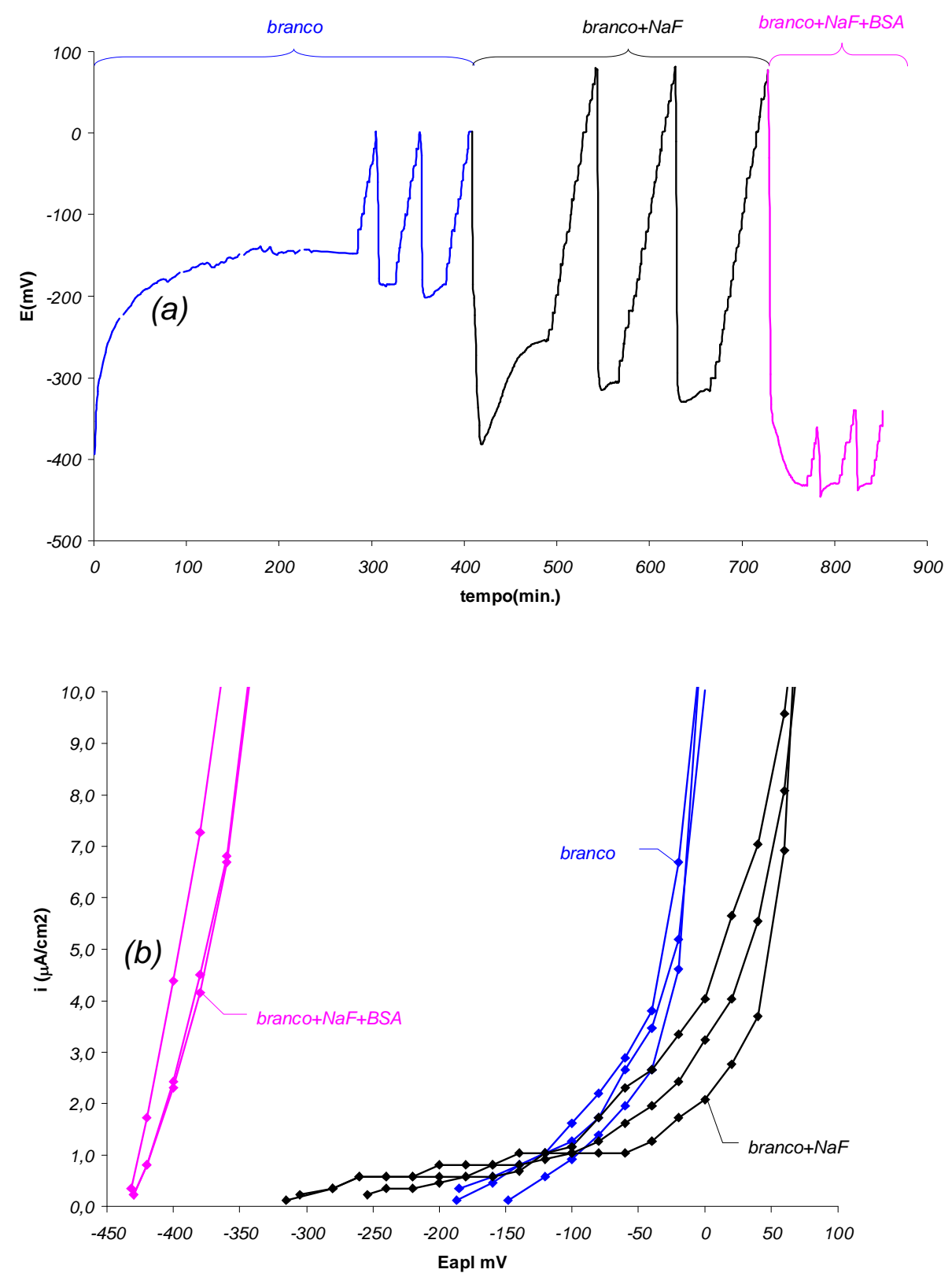

Figura 25. Determinação do potencial de circuito aberto estacionário ou $\mathrm{E}_{\text {corr }}$ (a) e curvas de polarização potenciostática anódica (b) da liga Ni-Cr-Mo-Ti, mostrando o efeito da adição de $\mathrm{NaF}$ ao branco e de $\mathrm{BSA}$ ao branco+NaF. 
As figuras 26(a) e 26(b) mostram, respectivamente, a determinação do potencial de circuito aberto estacionário $\left(E_{\text {corr }}\right)$ e as curvas de polarização potenciostática anódica, para a liga Ni-Cr-Mo-Ti em meio de cloreto de sódio $9 \mathrm{~g} \mathrm{~L}^{-1}$ (branco), ácido cítrico $11 \mathrm{~g} \mathrm{~L}^{-1}$ adicionado ao branco (branco $+\mathrm{H}_{3} \mathrm{Cit}$ ), e albumina bovina $0,20 \mathrm{~g} \mathrm{~L}^{-1}$ adicionada ao branco $+\mathrm{H}_{3} \mathrm{Cit}$ (branco $+\mathrm{H}_{3} \mathrm{Cit}+\mathrm{BSA}$ ).
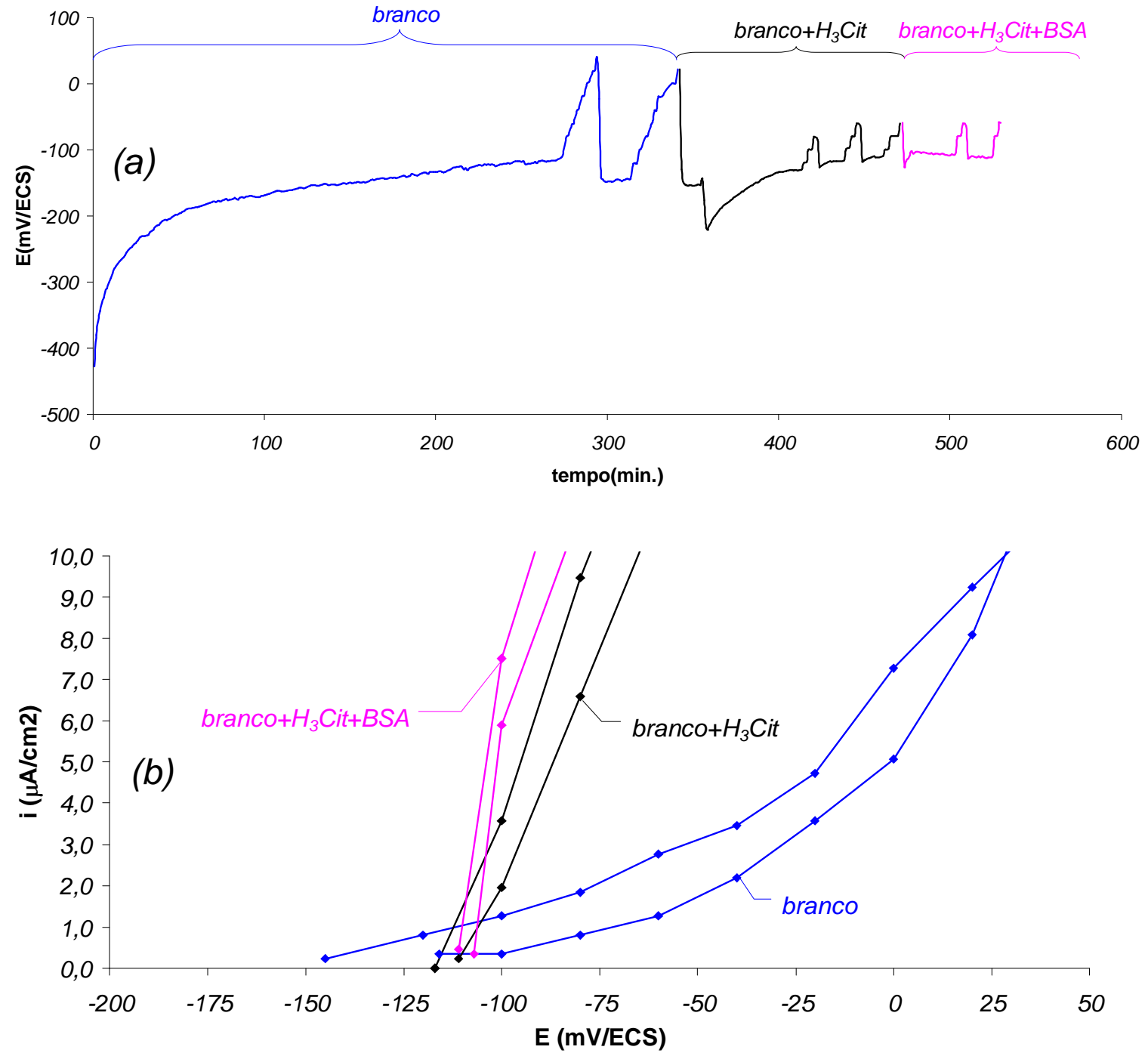

Figura 26. Determinação do potencial de circuito aberto estacionário ou $\mathrm{E}_{\text {corr }}$ (a) e curvas de polarização potenciostática anódica (b) da liga Ni-Cr-Mo-Ti, mostrando o efeito da adição de $\mathrm{H}_{3} \mathrm{Cit}$ ao branco e de BSA ao branco+ $\mathrm{H}_{3} \mathrm{Cit}$. 
Na tabela 7, são apresentados os valores de potencial de corrosão ( $\left.E_{\text {corr }}\right)$, potencial de subida de corrente $\left(E_{s c}\right)$, faixa passiva (FP), densidade de corrente de passivação (i $\left.i_{\text {pass }}\right)$ e, quando é o caso, de resistência de polarização $\left(R_{\text {pol }}\right)$, para todos os meios estudados. A figura 27 destaca, em (a), os valores de $E_{\text {corr }}$ e, em (b), os de $E_{s c}$, na forma de colunas, com barras representando os desvios-padrão.

Tabela 7 - Comparação dos parâmetros eletroquímicos obtidos da adição dos meios de estudo ao branco para liga Ni-Cr-Mo-Ti. Os valores entre parêntesis indicam o número de ensaios.

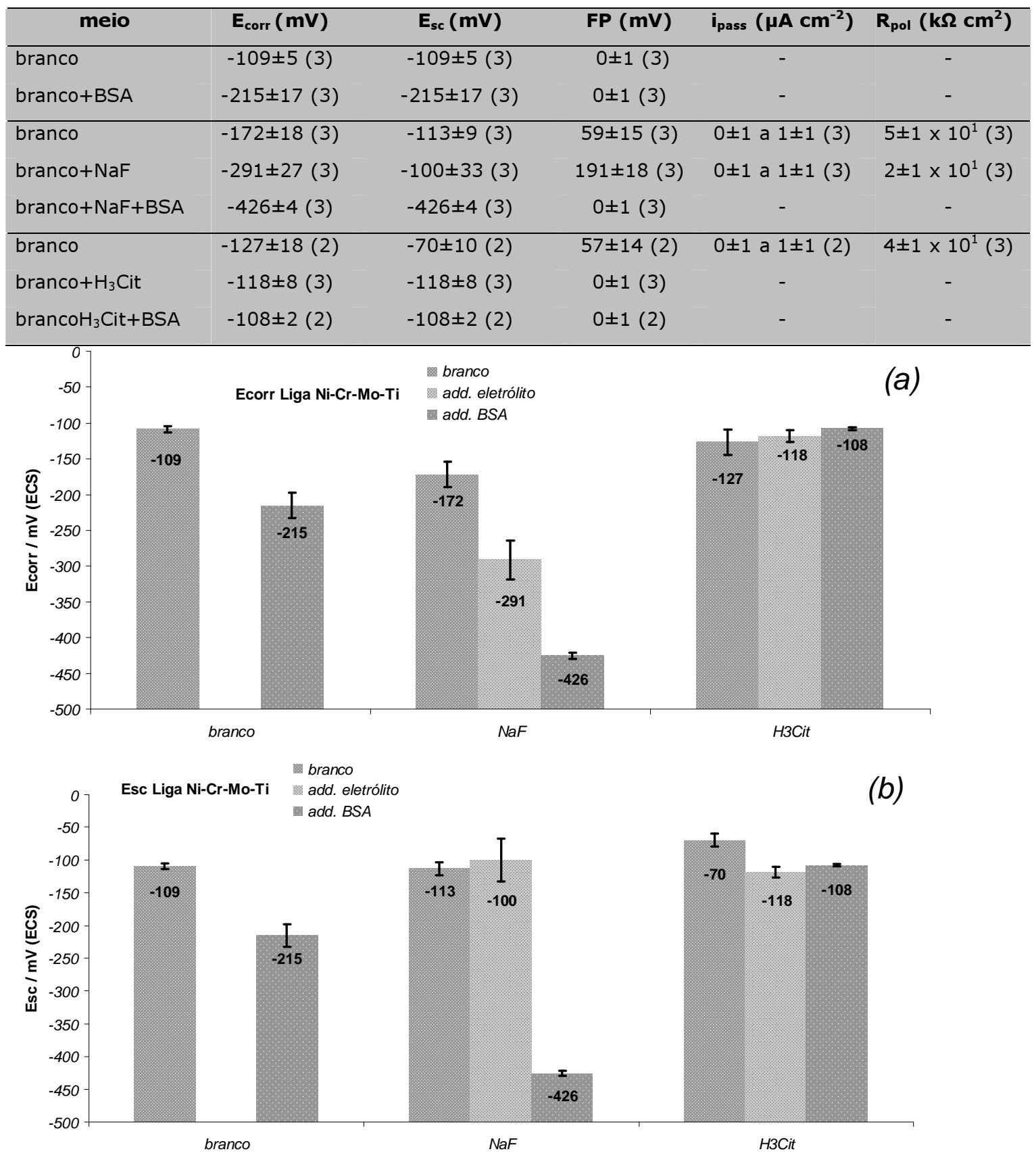

Figura 27. Valores de $\mathrm{E}_{\text {corr }}$ (a) e $\mathrm{E}_{\mathrm{sc}}$ (b) dos estudos realizados com a liga Ni-Cr-Mo-Ti. 
Observa-se que a liga $\mathrm{Ni}-\mathrm{Cr}-\mathrm{Mo}-\mathrm{Ti}$ apresenta uma superfície bem irreprodutível, conforme se comparam os valores de $E_{c o r r,} E_{s c}, F P$ e i pass para 0 branco nas diferentes superfícies ensaiadas. A faixa passiva é muito pequena, no máximo igual a $60 \mathrm{mV}$, e em outros experimentos mostra-se inexistente.

Nota-se que a adição de NaF ao branco torna bem mais negativos os valores de $E_{\text {corr, }}$ mas não altera os valores de $E_{s c}$ e de $i_{\text {pass, }}$ indicando uma modificação na composição da interfase, sem alteração das características do filme passivante.

O ácido cítrico tem o efeito de reduzir a zero a faixa passiva quando adicionado ao branco, indicando o rompimento do filme passivo no próprio $\mathrm{E}_{\text {corr }}$. Atribui-se este efeito ao baixo valor de $\mathrm{pH}$ quando da adição do $\mathrm{H}_{3} \mathrm{Cit}$, dissolvendo os óxidos. Não se pode descartar, também, a possibilidade de complexação dos íons metálicos pelo ânion citrato.

A albumina bovina torna mais negativos $E_{c o r r}$ e $E_{s c}$ quando adicionada ao branco e ao branco $+\mathrm{NaF}$, principalmente neste último meio. Pode ser bem visualizado, pela curva de polarização da figura 25, o total desaparecimento do filme passivante, desde $o E_{c o r r}$ quando da adição da proteína. Nota-se que a adsorção da BSA é maior em meio de $\mathrm{NaF}(\mathrm{pH} \approx 7)$. Por se encontrar acima do seu ponto isoelétrico, portanto carregada negativamente, a sua adsorção sobre a liga Ni-Cr-Mo-Ti no $E_{c o r r}$ deve ocorrer em virtude da formação de complexos com metais de transição (Jackson et alii [21]). O eletrodo, no $E_{\text {corr, }}$ encontra-se a um potencial bem mais negativo, diferente dos outros materiais estudados, o que torna difícil atribuir este resultado a um efeito puramente eletrostático. 


\subsection{Estudos eletroquímicos com a amálgama de Ag-Sn-Cu-Zn}

As figuras 28(a) e 28(b) mostram, respectivamente, a determinação do potencial de circuito aberto estacionário $\left(E_{\text {corr }}\right)$ e as curvas de polarização potenciostática anódica, para a amálgama $\mathrm{Ag}-\mathrm{Sn}-\mathrm{Cu}-\mathrm{Zn}$ em meio de cloreto de sódio $9 \mathrm{~g} \mathrm{~L}^{-1}$ (branco), e com 0,20 $\mathrm{g} \mathrm{L}^{-1}$ de albumina bovina adicionada a esse meio (branco+BSA).
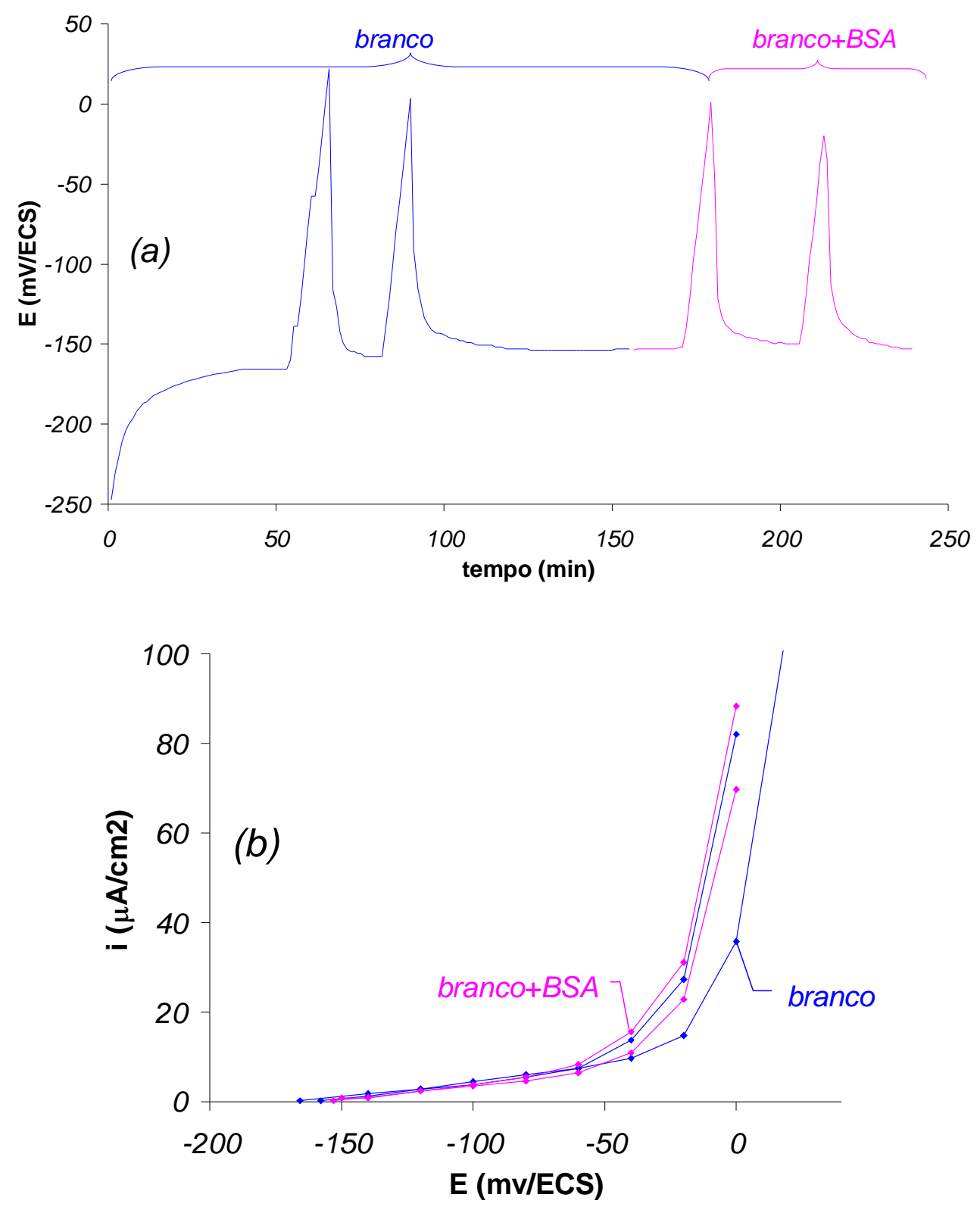

Figura 28. Determinação do potencial de circuito aberto estacionário ou Ecorr (a) e curvas de polarização potenciostática anódica (b) da amálgama Ag-Sn-Cu-Zn, mostrando o efeito da adição de BSA ao branco. 
As figuras 29(a) e 29(b) mostram, respectivamente, a determinação do potencial de circuito aberto estacionário $\left(E_{\text {corr }}\right)$ e as curvas de polarização potenciostática anódica, para a amálgama $\mathrm{Ag}-\mathrm{Sn}-\mathrm{Cu}-\mathrm{Zn}$ em meio de cloreto de sódio $9 \mathrm{~g} \mathrm{~L}^{-1}$ (branco), fluoreto de sódio $3,3 \mathrm{~g} \mathrm{~L}^{-1}$ adicionado ao branco (branco+NaF), e albumina bovina $0,20 \mathrm{~g} \mathrm{~L}^{-1}$ adicionada ao branco+NaF (branco+NaF+BSA).
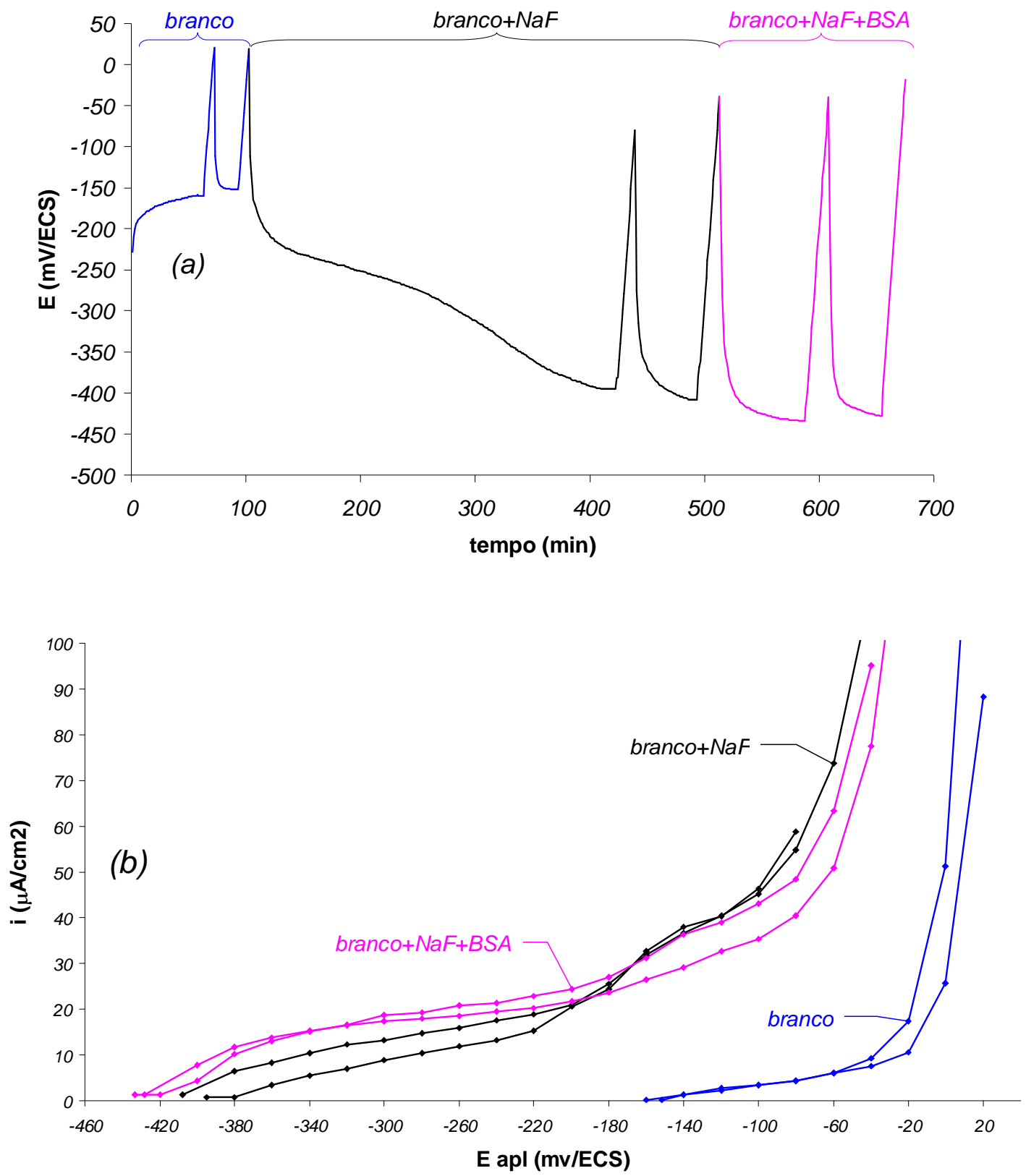

Figura 29. Determinação do potencial de circuito aberto estacionário ou $E_{\text {corr }}$ (a) e curvas de polarização potenciostática anódica (b) da amálgama Ag-Sn-Cu-Zn, mostrando o efeito da adição de $\mathrm{NaF}$ ao branco e de $\mathrm{BSA}$ ao branco+NaF. 
As figuras 30(a) e 30(b) mostram, respectivamente, a determinação do potencial de circuito aberto estacionário $\left(E_{\text {corr }}\right)$ e as curvas de polarização potenciostática anódica, para a amálgama Ag-Sn-Cu-Zn em meio de cloreto de sódio $9 \mathrm{~g} \mathrm{~L}^{-1}$ (branco), ácido cítrico $11 \mathrm{~g} \mathrm{~L}^{-1}$ adicionado ao branco (branco $+\mathrm{H}_{3} \mathrm{Cit}$ ), e albumina bovina $0,20 \mathrm{~g} \mathrm{~L}^{-1}$ adicionada ao branco $+\mathrm{H}_{3} \mathrm{Cit}$ (branco $+\mathrm{H}_{3} \mathrm{Cit}+\mathrm{BSA}$ ).
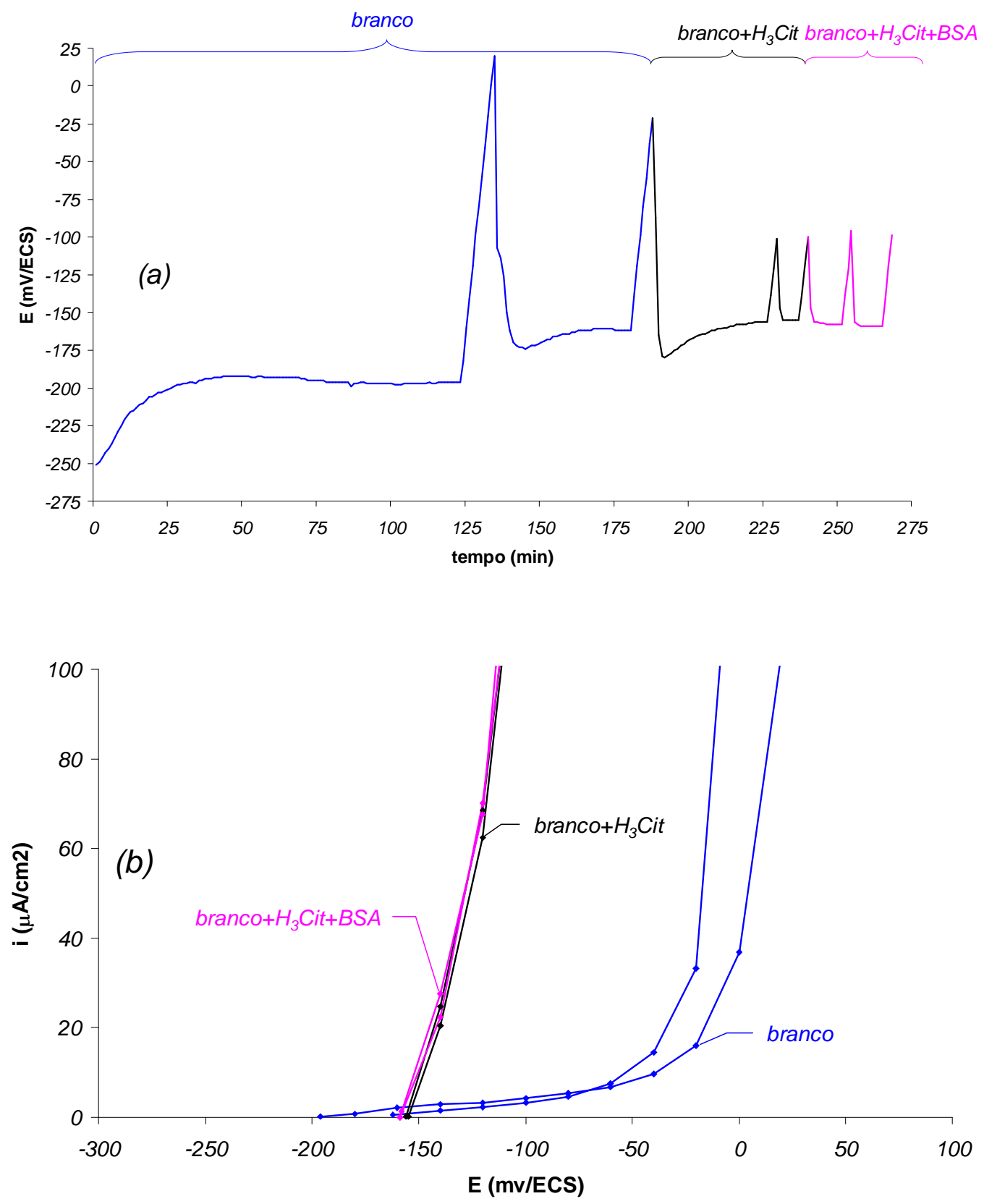

Figura 30. Determinação do potencial de circuito aberto estacionário ou Ecorr (a) e curvas de polarização potenciostática anódica (b) da amálgama Ag-Sn-Cu-Zn, mostrando o efeito da adição de $\mathrm{H}_{3} \mathrm{Cit}$ ao branco e de $\mathrm{BSA}$ ao branco+ $\mathrm{H}_{3} \mathrm{Cit}$. 
Na tabela 8, são apresentados os valores de potencial de corrosão ( $\left.E_{\text {corr }}\right)$, potencial de subida de corrente $\left(E_{s c}\right)$, faixa passiva (FP), densidade de corrente de passivação (i $\left.i_{\text {pass }}\right)$ e, quando é o caso, de resistência de polarização $\left(R_{\text {pol }}\right)$, para todos os meios estudados. A figura 31 destaca, em (a), os valores de $E_{\text {corr }}$ e, em (b), os de $E_{s c}$, na forma de colunas, com barras representando os desvios-padrão.

Tabela 8 - Comparação dos parâmetros eletroquímicos obtidos da adição dos meios de estudo ao branco para a amálgama $\mathrm{Ag}-\mathrm{Sn}-\mathrm{Cu}-\mathrm{Zn}$. Os valores entre parêntesis indicam o número de ensaios.

\begin{tabular}{|c|c|c|c|c|c|}
\hline meio & $E_{\text {corr }}(m V)$ & $E_{s c}(m V)$ & FP $(\mathrm{mV})$ & $i_{\text {pass }}\left(\mu \mathrm{A} \mathrm{cc^{-2 } )}\right.$ & $R_{\text {pol }}\left(k \Omega \mathrm{cm}^{2}\right)$ \\
\hline branco & $-159 \pm 5(3)$ & $-40 \pm 10(2)$ & $119 \pm 8(2)$ & $0 \pm 1$ a $9 \pm 1(2)$ & $11 \pm 1(2)$ \\
\hline branco+BSA & $-152 \pm 1$ & $-50 \pm 1(2)$ & $102 \pm 1(2)$ & $0 \pm 1$ a $7 \pm 1(2)$ & $13 \pm 2(2)$ \\
\hline branco & $-156 \pm 4(3)$ & $-40 \pm 10(2)$ & $116 \pm 9(2)$ & $0 \pm 1$ a $7 \pm 1(2)$ & $12 \pm 1(2)$ \\
\hline branco+NaF & $-402 \pm 7(2)$ & $-210 \pm 10(2)$ & $192 \pm 8(2)$ & $0 \pm 1$ a $18 \pm 3(2)$ & $12 \pm 1(2)$ \\
\hline branco+NaF+BSA & $-431 \pm 3(2)$ & $-85 \pm 5(2)$ & $346 \pm 4(2)$ & $0 \pm 1$ a $42 \pm 1$ & $9 \pm 1(2)$ \\
\hline branco & $-179 \pm 17(2)$ & $-40 \pm 1(2)$ & $139 \pm 17(2)$ & $0 \pm 1$ a $8 \pm 1(2)$ & $20 \pm 1(2)$ \\
\hline branco $+\mathrm{H}_{3} \mathrm{Cit}$ & $-156 \pm 1(2)$ & $-156 \pm 1(2)$ & $0 \pm 1(2)$ & $0 \pm 1(2)$ & - \\
\hline branco ${ }_{3} \mathrm{Cit}+\mathrm{BSA}$ & $-159 \pm 1(2)$ & $-159 \pm 1(2)$ & $0 \pm 1(2)$ & $0 \pm 1(2)$ & - \\
\hline
\end{tabular}

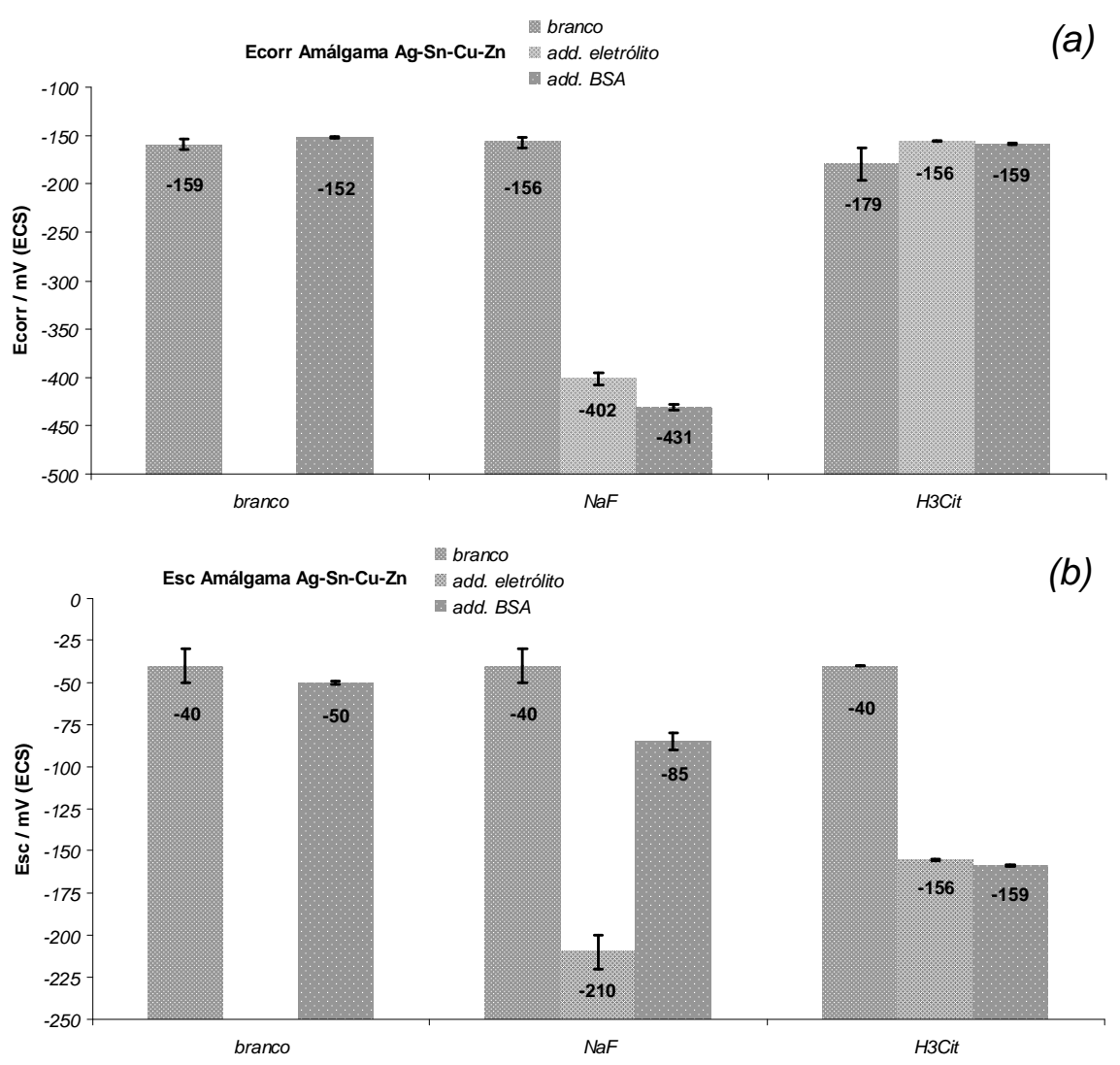

Figura 31. Valores de $\mathrm{E}_{\text {corr }}$ (a) e $\mathrm{E}_{\mathrm{sc}}$ (b) dos estudos realizados com a amálgama. 
A análise da tabela 8 permite dizer que a amálgama Ag-Sn-Cu-Zn se mostra com superfície reprodutível em meio de $\mathrm{NaCl}$, com faixa passiva da ordem de $120 \mathrm{mV}$.

As figuras 28 a 31 e a tabela 8 mostram que o único soluto que exerce algum efeito significativo sobre o $E_{\text {corr }}$ da interfase amálgama/branco é o NaF, que torna bem mais negativo o valor desse parâmetro e eleva consideravelmente os valores de $i_{\text {pass. }}$. Esses resultados sugerem que o ín fluoreto modifica as características do filme passivante, tornando-o menos protetor, provavelmente competindo com o oxigênio e os íons cloreto na interfase.

Embora, por um lado, $\mathrm{H}_{3} \mathrm{Cit}$ não afete o $\mathrm{E}_{\text {corr }}$ quando adicionado ao branco, reduz, por outro, sua faixa passiva (que é da ordem de $100 \mathrm{mV}$ ) para zero. A presença desse ácido leva, portanto, a superfície da amálgama ao estado ativo, isto é, não-passivado. A razão para esse comportamento de dissolução do filme passivante pode ser atribuída ao baixo valor de $\mathrm{pH}$ da nova solução obtida. $\mathrm{O}$ efeito do íon citrato na dissolução da liga Ni-Cr-Mo-Ti estudada anteriormente e da amálgama, através de um processo de complexação dos íons metálicos, é uma possibilidade que precisa ser investigada, além do efeito mencionado da redução do $\mathrm{pH}$ sobre a superfície dos dois materiais metálicos.

A albumina torna mais negativos os valores de $\mathrm{E}_{\text {corr }}$ quando adicionada a branco+NaF. Por outro lado, BSA tem o efeito de ampliar, de um valor da ordem de $100 \mathrm{mV}$, a faixa passiva quando acrescida ao mesmo meio. Como o ponto isoelétrico (pI) da albumina bovina vale 5,5 (Carter et alii [18]), a pHs mais altos que esse valor (como é o caso da solução contendo íons fluoreto, que sofrem hidrólise, elevando a alcalinidade do meio), essa proteína assume a forma aniônica, aumentando sua atração eletrostática pelo eletrodo quando a ele se impõem potenciais mais positivos que $E_{\text {corr. }}$ Isso aumenta a adsorção da proteína pela superfície metálica, formando uma barreira protetora sobre a camada passiva da amálgama. 


\subsection{Estudos eletroquímicos com o Ti-cp}

A figura 32(a) mostra curvas de potencial de circuito aberto em função do tempo para o Ti-cp, comparando imersão em solução de cloreto de sódio $9 \mathrm{~g} \mathrm{~L}^{-1}$ (branco) com imersão em BSA $0,20 \mathrm{~g} \mathrm{~L}^{-1}$ adicionada ao branco (branco+BSA). 32(b) mostra o efeito da adição de fluoreto de sódio $3,3 \mathrm{~g} \mathrm{~L}^{-1}$ ao branco (branco+NaF), e de BSA 0,20 g L $\mathrm{g}^{-1}$ ao branco+NaF (branco+NaF+BSA). 32(c) mostra o efeito da adição de ácido cítrico $11 \mathrm{~g} \mathrm{~L}^{-1}$ ao branco (branco $+\mathrm{H}_{3} \mathrm{Cit}$ ), e de BSA $0,20 \mathrm{~g} \mathrm{~L}^{-1}$ ao branco $+\mathrm{H}_{3} \mathrm{Cit}$ (branco $+\mathrm{H}_{3} \mathrm{Cit}+\mathrm{BSA}$ ).
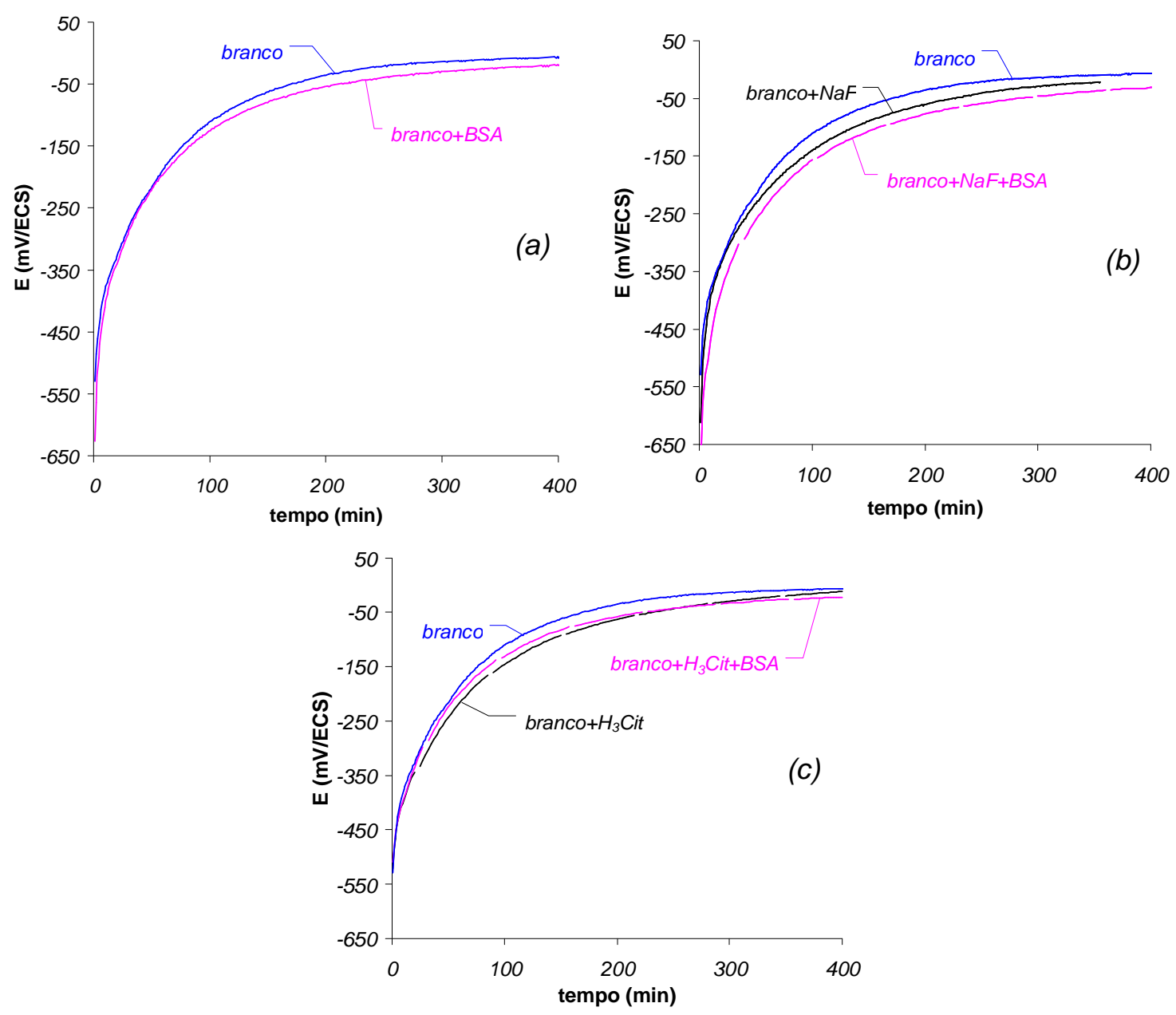

Figura 32. Curvas de potencial de circuito aberto em função do tempo do Ti-cp, mostrando o efeito da adição de BSA ao branco (a); o efeito de $\mathrm{NaF}$ ao branco e de BSA ao branco+NaF (b); o efeito de $\mathrm{H}_{3} \mathrm{Cit}$ ao branco e de BSA ao branco+ $\mathrm{H}_{3} \mathrm{Cit}$ (c). 
A figura 33(a) compara curvas de polarização potenciostática anódica do Ti-cp em meios de branco e branco+BSA; 33(b) compara branco, branco+NaF e branco+NaF+BSA; 33(c) compara branco, branco $+\mathrm{H}_{3} \mathrm{Cit}$ e branco $+\mathrm{H}_{3} \mathrm{Cit}+\mathrm{BSA}$.
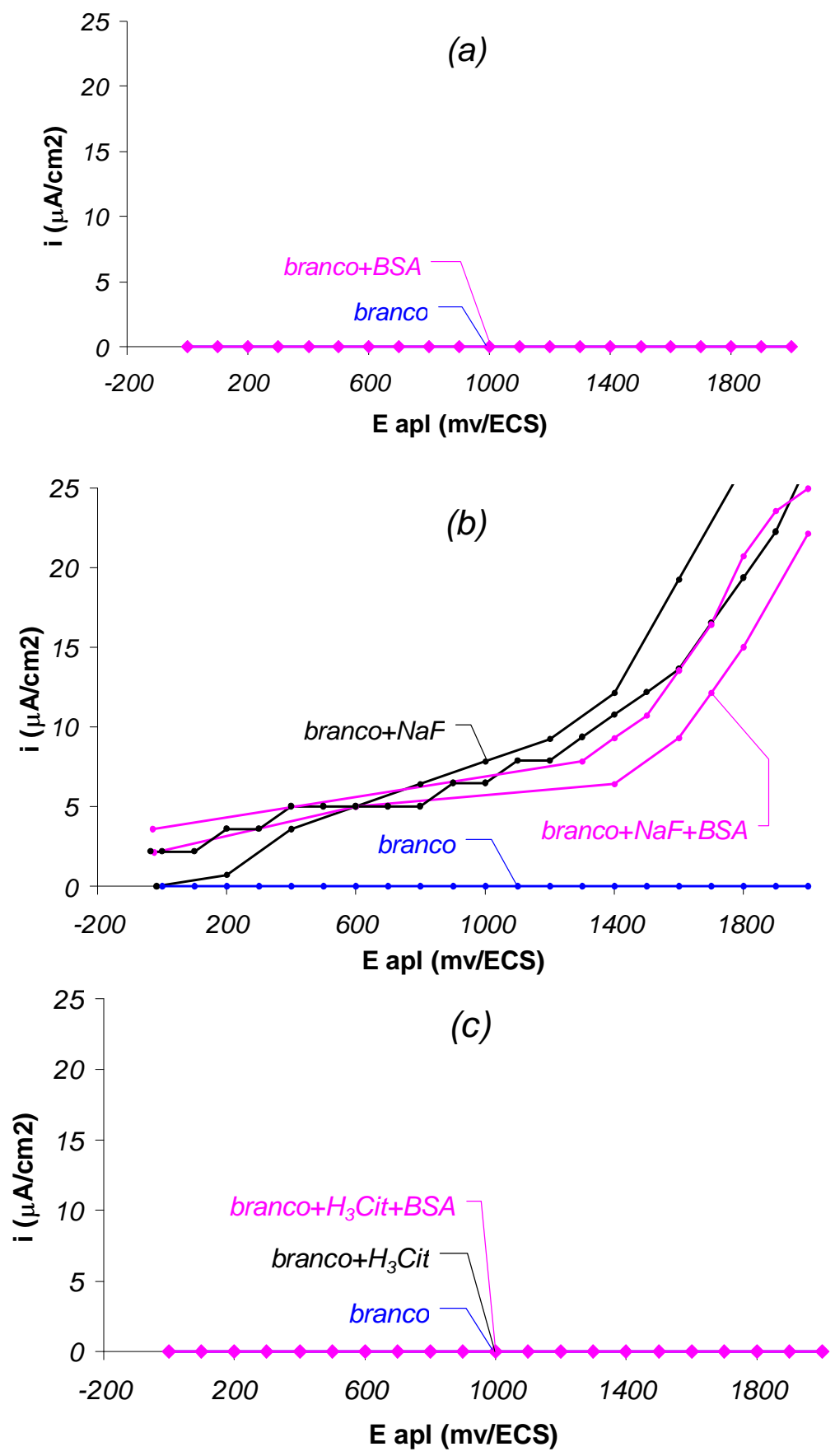

Figura 33. Curvas de polarização potenciostática anódica do Ti-cp, mostrando o efeito da adição de BSA ao branco (a); o efeito de $\mathrm{NaF}$ ao branco e de BSA ao branco+NaF (b); o efeito de $\mathrm{H}_{3}$ Cit ao branco e de BSA ao branco $+\mathrm{H}_{3} \mathrm{Cit}$ (c). 
Na tabela 9, são apresentados os valores de potencial de corrosão ( $\left.\mathrm{E}_{\text {corr }}\right)$, potencial de subida de corrente $\left(E_{s c}\right)$, faixa passiva (FP), densidade de corrente de passivação (i $\left.i_{\text {pass }}\right)$ e, quando é o caso, de resistência de polarização $\left(R_{\text {pol }}\right)$, para todos os meios estudados. A figura 34 destaca, em (a), os valores de $E_{\text {corr }}$ e, em (b), os de $E_{s c}$, na forma de colunas, com barras representando os desvios-padrão.

Tabela 9 - Comparação dos parâmetros eletroquímicos obtidos da adição dos meios de estudo ao branco para o Ti-cp. Os valores entre parêntesis indicam o número de ensaios.

\begin{tabular}{|c|c|c|c|c|c|}
\hline meio & $E_{\text {corr }}(m V)$ & $E_{s c}(m V)$ & FP $(\mathbf{m V})$ & $i_{\text {pass }}\left(\mu \mathrm{A} \mathrm{cm} \mathrm{cm}^{-2}\right)$ & $R_{p o l}\left(k \Omega \mathrm{cm}^{2}\right)$ \\
\hline branco & $1 \pm 8(2)$ & $>2000$ & $>1992 \pm 8(2)$ & $0 \pm 1(2)$ & - \\
\hline branco+BSA & $-28 \pm 3(2)$ & $>2000$ & $>2028 \pm 3(2)$ & $0 \pm 1(2)$ & - \\
\hline branco & $1 \pm 8(2)$ & $>2000$ & $>1992 \pm 8(2)$ & $0 \pm 1(2)$ & - \\
\hline branco $+\mathrm{NaF}$ & $-30 \pm 6(2)$ & $1300 \pm 1(2)$ & $1330 \pm 6(2)$ & $1 \pm 1$ a $9 \pm 1$ (2) & $1 \pm 1 \times 10^{2}(2)$ \\
\hline branco+NaF+BSA & $-48 \pm 1(2)$ & $1400 \pm 1(2)$ & $1448 \pm 1(2)$ & $3 \pm 1$ a $8 \pm 1(2)$ & $2 \pm 1 \times 10^{2}(2)$ \\
\hline branco & $1 \pm 8(2)$ & $>2000$ & $>1992 \pm 8(2)$ & $0 \pm 1(2)$ & - \\
\hline branco $+\mathrm{H}_{3} \mathrm{Cit}$ & $-12 \pm 1(1)$ & $>2000$ & $>2012 \pm 1(1)$ & $0 \pm 1(2)$ & - \\
\hline brancoH ${ }_{3} \mathrm{Cit}+\mathrm{BSA}$ & $-22 \pm 1(1)$ & $>2000$ & $>2022 \pm 1(1)$ & $0 \pm 1(2)$ & - \\
\hline
\end{tabular}

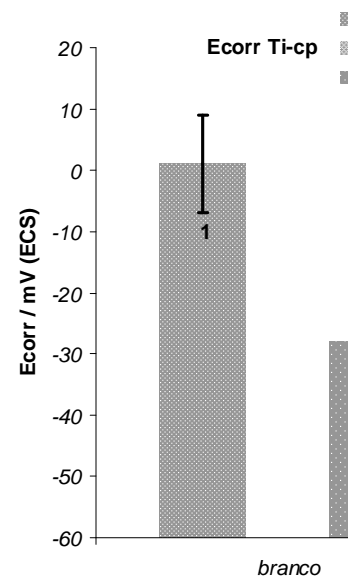

(a)

add. BSA

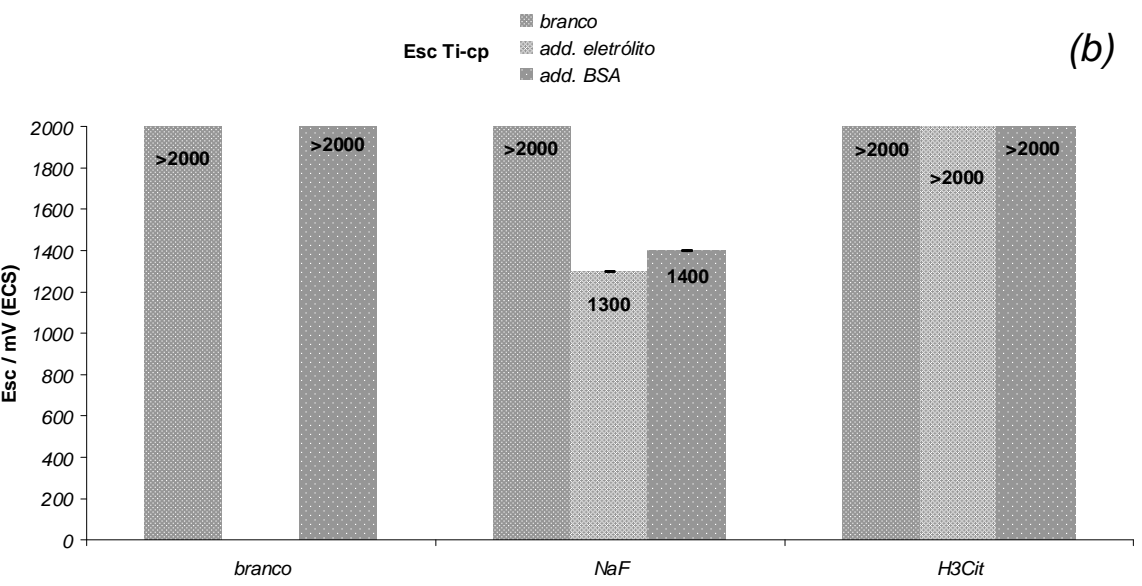

Figura 34. Valores de $\mathrm{E}_{\text {corr }}$ (a) e $\mathrm{E}_{\mathrm{sc}}$ (b) dos estudos realizados com o Ti-cp . 
Analisando a tabela 9, verifica-se que a superfície do Ti-cp é bem reprodutível em todos os meios estudados e, com exceção dos meios com $\mathrm{NaF}$, esse material é encontrado passivado em toda a faixa de polarização anódica estudada (até $2000 \mathrm{mV}$ ).

Os resultados apresentados nas figuras 32 a 34 e na tabela 9 indicam que a adição de $\mathrm{NaF}$ e $\mathrm{H}_{3} \mathrm{Cit}$ ao branco torna mais negativo o $\mathrm{E}_{\text {corr }}$ do Ti-cp. $\mathrm{O}$ fato de ocorrer subida de corrente em $1300 \mathrm{mV}$ quando se adiciona $\mathrm{NaF}$ ao branco, aliada à mudança do $E_{c o r r}$ para valores mais negativos, confirma as informações fornecidas pela literatura e descritas no item 1.4: os íons fluoreto exercem ação complexante sobre o Ti-IV presente na camada superficial de óxidos passivantes do titânio-cp, mesmo na concentração usada neste trabalho $\left(3,3 \mathrm{~g} \mathrm{~L}^{-1} \mathrm{em} \mathrm{NaF}\right.$, 0 que representa $1500 \mathrm{ppm}$ em fluoreto), a qual é correntemente encontrada em dentifrícios comerciais.

É importante salientar, no caso do ácido cítrico, que a redução do $\mathrm{pH}$ da solução de $\mathrm{NaCl}$ não modifica as características passivantes do filme de óxidos formado sobre o titânio, diferentemente do observado para as ligas Ni-Cr-Mo-Ti e amálgama Ag-Cu-Sn-Zn.

A albumina torna mais negativos os valores de $\mathrm{E}_{\text {corr }}$ quando adicionada a todos os meios testados, o que mostra sua presença adsorvida na interface óxidos/solução. Por outro lado, a BSA tem o efeito de ampliar, de um valor da ordem de $100 \mathrm{mV}$, a faixa passiva quando acrescida ao branco+NaF. De maneira semelhante ao observado para a interfase amálgama/solução, esse efeito da proteína pode ser atribuído a uma adsorção física de natureza eletrostática, intensificada pela elevação do pH da solução e pela elevação do potencial. 


\subsection{Comparação entre o comportamento eletroquímico das ligas} Au-Pt-Pd e Ni-Cr-Mo-Ti

Conforme apresentado no capítulo 1, ligas nobres vêm sendo substituídas por ligas de metais passivados, em virtude do alto custo das primeiras em relação às últimas. Neste trabalho, servem de exemplos de materiais nobres e passivados, respectivamente, as ligas Au-Pt-Pd e Ni-Cr-Mo-Ti. Tais ligas são igualmente utilizadas em próteses dentárias, e a liga áurica, em próteses sobre implantes osseointegrados. Mais recentemente, a liga quaternária Ni-Cr-Mo-Ti vem sendo desenvolvida com a mesma finalidade. Nesse contexto, torna-se importante, neste trabalho, estabelecer uma comparação entre o comportamento eletroquímico desses dois materiais.

Comparando as tabelas 6 (p. 49) e 7 (p. 55), respectivamente para as ligas Au-Pt-Pd e Ni-Cr-Mo-Ti, pode-se observar o que segue:

a) $\mathrm{O}$ potencial de corrosão da liga áurica em meio de $\mathrm{NaCl} 9 \mathrm{~g} \mathrm{~L}^{-1}$ (branco), nas superfícies estudadas é de $102 \pm 2 \mathrm{mV} / \mathrm{ECS}$, enquanto o da liga $\mathrm{Ni}-\mathrm{Cr}-\mathrm{Mo}-\mathrm{Ti}$ varia entre -109 mV/ECS e -214 mV/ECS. Além dos valores reprodutíveis apresentados pela liga nobre, o seu $E_{\text {corr }}$ é cerca de $200 \mathrm{mV}$ a $300 \mathrm{mV}$ mais positivo do que o da liga passivada.

b) 0 potencial de elevação de corrente da liga áurica no branco se situa entre $740 \mathrm{mV} / \mathrm{ECS}$ e $760 \mathrm{mV} / \mathrm{ECS}$, correspondendo a uma faixa passiva de potencial de $650 \mathrm{mV}$. $O$ valor de $E_{s c}$ da liga de níquel no mesmo meio fica tão próximo do potencial de corrosão, que algumas de suas superfícies não apresentaram faixa passiva.

c) A liga áurica não muda seu comportamento eletroquímico por mudança de $\mathrm{pH}$; a liga de níquel passivada a pH próximo de 7 (branco+NaF) se apresenta com a superfície ativa, não-passivada, a pH próximo de 2 (branco $\left.+\mathrm{H}_{3} \mathrm{Cit}\right)$.

d) A presença de albumina não modifica o comportamento da liga áurica em qualquer dos meios estudados. A liga de níquel, em meio de branco+NaF, apresenta um deslocamento da ordem de $300 \mathrm{mV}$ no sentido negativo de potenciais quando ao meio se adiciona a proteína e perde o filme protetor. Nessas 
condições, essa liga apresenta um $\mathrm{E}_{\text {corr }}$ da ordem de $500 \mathrm{mV}$ mais negativo que o da liga áurica.

Esses resultados mostram a grande diferença de comportamento eletroquímico entre os dois materiais nos meios estudados, os quais simulam fluidos bucais. Os resultados obtidos com a liga Ni-Cr-Mo-Ti sugerem que ela pode sofrer corrosão em ambiente bucal, dependendo da composição dos fluidos orais.

É importante comparar também o comportamento eletroquímico dessas ligas com o do titânio (tabela 9, p. 64), devido ao emprego das mesmas como próteses sobre implantes ósseointegrados:

a) A liga Au-Pt-Pd apresenta $E_{\text {corr }}$ mais positivo do que o Ti-cp em todos os meios estudados, com variações de potencial, entre um material e o outro, da ordem de $100 \mathrm{mV}$. A liga $\mathrm{Ni}-\mathrm{Cr}-\mathrm{Mo}-\mathrm{Ti}$ apresenta $\mathrm{E}_{\text {corr }}$ mais negativo que o Ti-cp, com variações de potencial, entre um material e outro, compreendidas entre $100 \mathrm{mV}$ e $400 \mathrm{mV}$, dependendo do meio e da superfície estudados.

b) A liga áurica se mostrou estável até cerca de $750 \mathrm{mV} / \mathrm{ECS}$, com uma faixa passiva compreendida entre $618 \mathrm{mV}$ e $802 \mathrm{mV}$, dependendo do meio estudado. O Ti-cp se mostrou passivado até 2 V/ECS em todos os meios estudados, com exceção dos meios contendo branco+NaF e branco+NaF+BSA, onde os valores de $E_{s c}$ foram iguais a $1300 \mathrm{mV} / E C S$ e a $1400 \mathrm{mV} / \mathrm{ECS}$, respectivamente. A liga $\mathrm{Ni}-\mathrm{Cr}-\mathrm{Mo}-\mathrm{Ti}$ mostrou, quando passivada, uma faixa passiva compreendida entre $60 \mathrm{mV}$ e $150 \mathrm{mV}$.

Esses resultados mostram a grande probabilidade de existência de par galvânico entre esses materiais metálicos, principalmente se a liga Ni-Cr-Mo-Ti for empregada como prótese sobre o implante ósseointegrado de Ti-cp.

Diante da irreprodutibilidade das superfícies da liga $\mathrm{Ni}-\mathrm{Cr}-\mathrm{Mo}-\mathrm{Ti}$, quando comparada à liga áurica, foram feitos exames superficiais por MEV das superfícies dos dois materiais após polimento, isto é, antes da imersão nos meios de ensaio. A figura 35 mostra os resultados obtidos, empregando uma mesma magnitude de ampliação (500x). Observa-se na liga áurica uma superfície homogênea, 
ressaltando apenas as falhas de polimento, enquanto a liga Ni-Cr-Mo-Ti apresenta nitidamente quatro fases distintas.

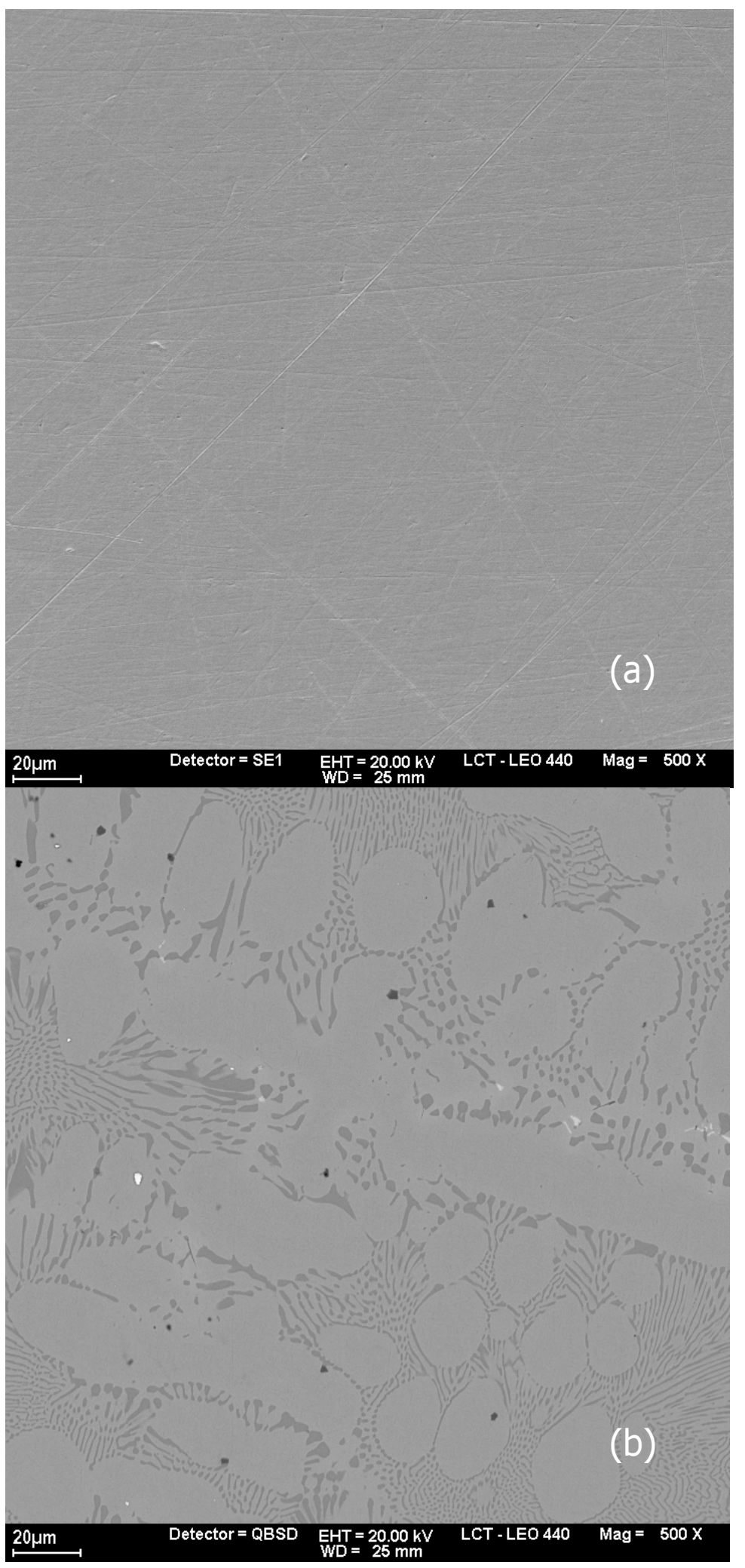

Figura 35. Imagens das ligas Au-Pt-Pd (a) e Ni-Cr-Mo-Ti (b) obtidas por microscópio eletrônico de varredura com ampliação de 500x . 
A figura 36 traz os resultados das análises de MEV e EDS realizadas na liga $\mathrm{Ni}-\mathrm{Cr}-\mathrm{Mo}-\mathrm{Ti}$, com o objetivo de caracterizar as fases existentes. As quatro fases mencionadas mostraram possuir os seguintes constituintes predominantes: (1) titânio, (2) níquel, (3) níquel-cromo e (4) molibdênio.
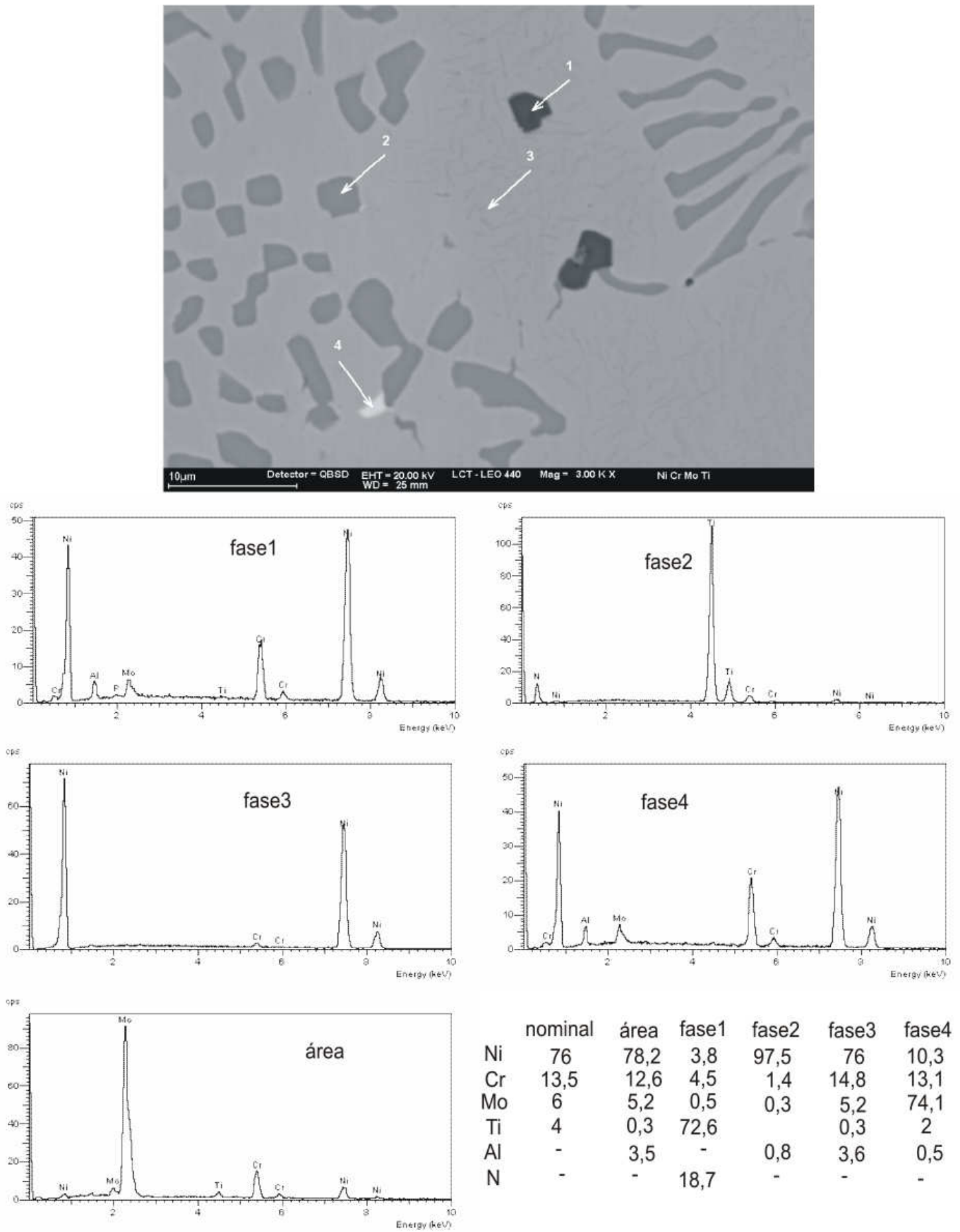

Figura 36. Resultados de MEV e EDS para a liga Ni-Cr-Mo-Ti. Os valores da tabela são percentagens mássicas de cada elemento. 
Ensaios por espectroscopia de impedância eletroquímica (EIE) foram realizados, no $E_{\text {corr, }}$ para as duas ligas, em meio de $\mathrm{NaCl} 9 \mathrm{~g} \mathrm{~L}^{-1}$, na ausência (s/ BSA) e na presença de albumina bovina a $0,20 \mathrm{~g} \mathrm{~L}^{-1}$ (c/ BSA), com o objetivo de obter informações sobre os valores de capacitância e de resistência de polarização na interfase metal-solução (figura 37). 0 intervalo de freqüências empregado foi entre $12,3 \mathrm{kHz}$ e 3,51 mHz e a amplitude de variação de potencial foi de $\pm 10 \mathrm{mV}$ em torno do potencial de corrosão $\left(\mathrm{E}_{\text {corr }}\right)$.

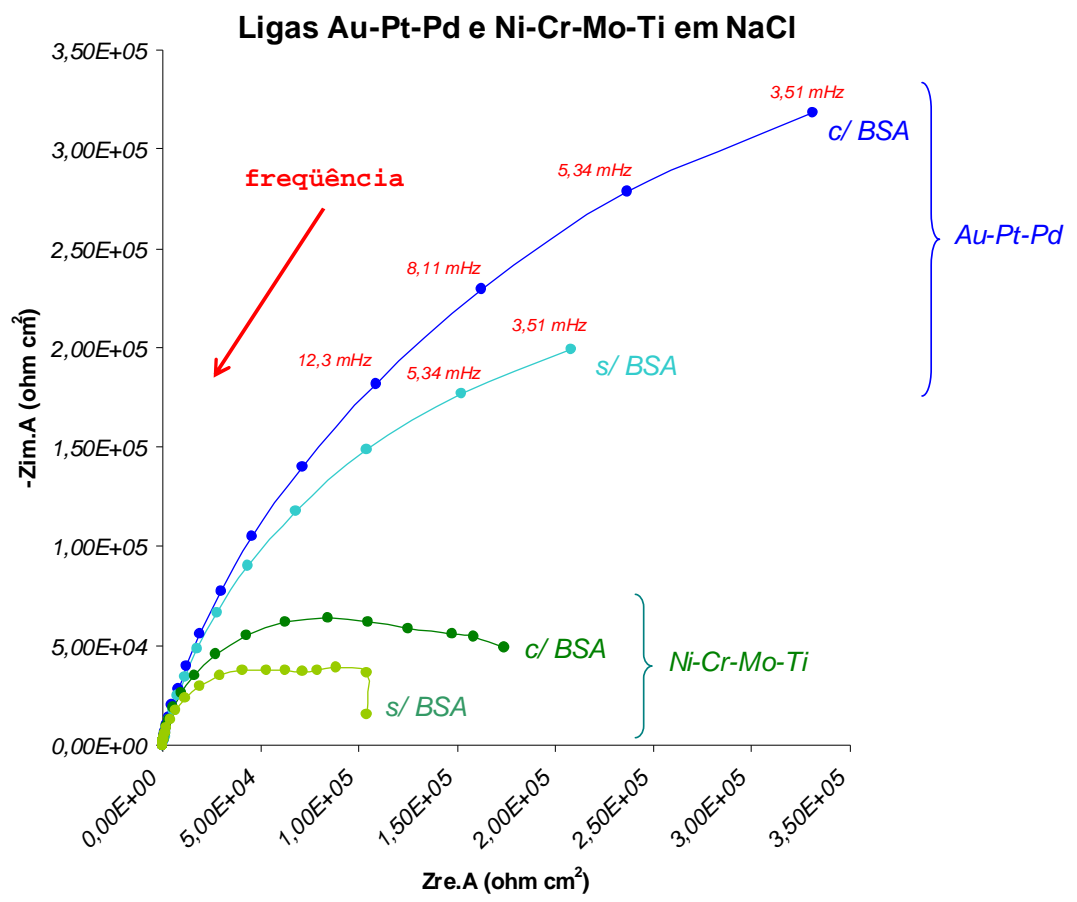

Figura 37. Diagramas de Nyquist para as ligas Au-Pt-Pd e Ni-Cr-Mo-Ti em NaCl $9 \mathrm{~g} \mathrm{~L}^{-1}$ ( $\mathrm{s}$ BSA) e de albumina bovina adicionada a esse meio (c/ BSA).

Na figura 37, observa-se, para a liga Au-Pt-Pd, um arco capacitivo que não fecha. Portanto, o valor da componente real de impedância na mais baixa frequêencia estudada ainda não corresponde à resistência de polarização. Nota-se para branco+BSA (c/ BSA) um comportamento qualitativamente semelhante ao do branco (s/ BSA), mas o valor de $Z_{\text {re, }}$ para a mais baixa freqüência estudada, é bem maior, embora da mesma ordem de grandeza. Os resultados sugerem que a proteína, no $E_{\text {corr, }}$ torna o filme mais passivante.

Observam-se, para a liga Ni-Cr-Mo-Ti, qualitativamente, a presença de mais de um arco capacitivo e um efeito considerável da proteína sobre o mecanismo 
das reações que ocorrem na superfície da liga. A presença de albumina eleva o valor de $Z_{\text {re }}$ no limite da mais baixa freqüência estudada. Na tabela 10 são apresentados os valores de $Z_{\mathrm{re}} \cdot \mathrm{A}$, em $\mathrm{M} \Omega \mathrm{cm}^{2}$, para os quatro sistemas estudados, bem como os valores de capacitância, calculados a partir da relação: $C=1 /\left(2 \pi f Z_{i m} A\right)$, onde $Z_{\text {im }}$ corresponde ao valor da componente imaginária da impedância, medida na forma de uma resistência, e A é a área do eletrodo. Esses valores de $C$ foram obtidos a uma freqüência elevada $(12,3 \mathrm{kHz})$ na qual se admite ser possível obter informações sobre capacitância na interfase metalsolução (Santos [22]), sem a interferência significativa de processos faradaicos.

Tabela 10. Valores de $\mathrm{Z}_{\mathrm{re}} \cdot \mathrm{A}(\mathrm{f}=3,51 \mathrm{mHz})$ e de $\mathrm{C}(\mathrm{f}=12,3 \mathrm{kHz})$ para as ligas Au-Pt-Pd e Ni-Cr-Mo-Ti nos meios branco e branco+BSA.

\begin{tabular}{lcc}
\multicolumn{1}{c}{ Interfase } & $\mathbf{Z}_{\mathbf{r e}} \mathbf{A} / \mathbf{M o h m s} \mathbf{~ c m}^{\mathbf{2}}$ & $\mathbf{C ~} / \boldsymbol{\mu F ~ \mathbf { ~ c m } ^ { - 2 }}$ \\
\hline Liga Au-Pt-Pd/branco & 0,21 & 10,8 \\
Liga Au-Pt-Pd/branco+BSA & 0,33 & 9,23 \\
\hline Liga Ni-Cr-Mo-Ti/branco & 0,10 & 4,0 \\
Liga Ni-Cr-Mo-Ti/branco+BSA & 0,17 & 5,0 \\
\hline
\end{tabular}

Comparando os dois materiais, observa-se que o valor da componente real de impedância (vezes a área) na mais baixa freqüência estudada é cerca de duas vezes maior para a liga Au-Pt-Pd que para a liga $\mathrm{Ni}-\mathrm{Cr}-\mathrm{Mo}-\mathrm{Ti}$. Esses resultados comprovam que a superfície desta última liga analisada se encontra passivada. É importante salientar que, embora essa liga apresente uma grande irreprodutibilidade de superfície, este resultado de impedância concorda com alguns dos resultados obtidos por técnica estacionária (polarização potenciostática) onde as correntes de passivação foram da mesma ordem de grandeza para os dois materiais. Comparando os valores de capacitância, nota-se que, no caso da liga Au-Pt-Pd, a proteína exerce pouco efeito sobre a estrutura da interfase, reduzindo, em cerca de $10 \%$, o valor da capacitância. Para a liga $\mathrm{Ni}-\mathrm{Cr}-\mathrm{Mo}-\mathrm{Ti}$, a presença da proteína eleva de $25 \%$ o valor da capacitância. Nesse caso, o efeito da proteína é maior, sobre a estrutura da dupla camada elétrica, quando comparado ao observado para a liga áurica. 
Capítulo 4: Conclusões e Sugestões para Trabalhos Futuros 


\subsection{Conclusões}

- Quanto à comparação dos diferentes materiais de embutimento:

1) Eletrodos sólidos confeccionados com embutimento em teflon, embora apresentem comprovada inércia química, mostraram limitações quanto às dimensões das amostras metálicas neles inseridas e quanto à qualidade (relacionada à presença ou ausência de cargas em sua composição) do teflon usado no embutimento.

2) Resinas epóxi líquidas apresentam boa capacidade de adaptação aos diversos formatos e dimensões das amostras metálicas a serem embutidas, gerando eletrodos sólidos resistentes ao impacto e com boa vedação mecânica. Sofrem, entretanto, ataque quando em contato prolongado com meios ácidos, devido à hidrólise promovida por esses sistemas às suas ligações cruzadas.

3) Resinas do tipo epóxi-vinil-éster (EVER) baseadas em novolaca epoxidisada aliam as vantagens de inércia química a meios ácidos que o teflon possui, com as vantagens apresentadas pelas resinas epóxi: adaptação ao formato das amostras a serem embutidas, boa resistência mecânica dos eletrodos sólidos finais e boa qualidade de vedação. Mostraram-se uma alternativa interessante à confecção de eletrodos sólidos de materiais metálicos de dimensões reduzidas e formatos variáveis para investigação de seu comportamento no contato com soluções aquosas ácidas, como é o caso dos materiais de uso odontológico estudados neste trabalho.

4) Deve-se evitar o embutimento de peças contendo geometria rica em sulcos e frestas (como é o caso de parafusos, por exemplo), para a confecção de eletrodos sólidos ou outros compósitos que sejam submetidos a desbaste, mesmo no embutimento em resinas, pois esses sistemas podem sofrer infiltração de líquidos e gases, alterando suas propriedades.

5) O uso de soldas para fazer o contato entre amostras metálicas de ensaio (de dimensões reduzidas) e outros metais deve ser substituído preferencialmente por métodos outros de fixação, como rosqueamento da amostra metálica ou sua inserção, sob pressão, numa depressão criada no 
metal de contato, para evitar difusão dos constituintes da solda para a amostra de interesse.

- Caracterização eletroquímica das diferentes interfases material metálico/solução eletrolítica na ausência de albumina:

6) Em meio de $\mathrm{NaCl}$ : A liga áurica se mantém estável numa ampla faixa de potencial, da ordem de $600 \mathrm{mV}$, a contar do $\mathrm{E}_{\text {corr. }}$ A liga Ni-Cr-Mo-Ti, em virtude da alta irreprodutibilidade de sua superfície, ora se mostra passiva em faixas da ordem de $80 \mathrm{mV}$, ora não apresenta região passiva de potencial. A amálgama apresentou uma faixa passiva estável, da ordem de $120 \mathrm{mV}$. O Ticp se mostrou passivado em toda a faixa de potenciais investigada.

7) Em meio de $\mathrm{NaCl}+\mathrm{NaF}$ : No caso da liga áurica, a adição de fluoreto dificulta a oxidação dos metais na forma de complexos com cloreto. No caso da liga $\mathrm{Ni}$-Cr-Mo-Ti, a introdução desse eletrólito não altera as características do filme passivante. No caso da amálgama Ag-Cu-Sn-Zn, observa-se modificação das características do filme passivante, tornando-o menos protetor. O Ti-cp apresenta uma redução significativa na faixa passiva de potenciais, superior a $700 \mathrm{mV}$.

8) Em meio de $\mathrm{NaCl}+\mathrm{H}_{3} \mathrm{Cit}$ : No caso da liga áurica, a adição de $\mathrm{H}_{3} \mathrm{Cit}$ não afeta o comportamento eletroquímico da interfase metal/solução. Para a liga $\mathrm{Ni}-\mathrm{Cr}$-Mo-Ti observou-se o efeito de rompimento do filme, a partir do potencial de corrosão ( $\left.E_{\text {corr }}\right)$. Efeito semelhante de rompimento da camada passiva foi observado para a amálgama Ag-Sn-Cu-Zn. O filme passivo do Ti-cp se manteve estável em toda a faixa de potencial investigada. 
- Efeito da albumina no comportamento eletroquímico das interfases estudadas:

9) Sobre a liga Au-Pt-Pd: o efeito da BSA sobre os meios estudados não é significativo para a liga áurica.

10) Sobre a liga Ni-Cr-Mo-Ti: a BSA favorece a dissolução do filme passivo, mesmo no $E_{\text {corr, }}$ em todos os meios estudados.

11) Sobre a amálgama $\mathrm{Ag}-\mathrm{Sn}-\mathrm{Cu}-\mathrm{Zn}$ : a proteína não exerce efeito em meio de $\mathrm{NaCl}$; em meio de branco+NaF ela amplia a faixa passiva e em meio de branco $+\mathrm{H}_{3} \mathrm{Cit}$ ela não altera o comportamento da interfase.

12) Sobre o Ti-cp: o efeito da proteína só é observado em meio de branco+NaF, em que ela amplia a faixa passiva em $100 \mathrm{mV}$.

\section{- $\quad$ Conclusões gerais}

13) Além dessas conclusões, pode-se destacar que os potenciais de corrosão médios, em $\mathrm{NaCl}$ fisiológico, da liga áurica, $\mathrm{Ti}-\mathrm{cp}$, amálgama de prata e liga NiCr-Mo-Ti, aproximadamente: $100 \mathrm{mV}, 1 \mathrm{mV},-160 \mathrm{mV}$ e $-140 \mathrm{mV}$, respectivamente (em relação ao ECS), demonstram que diversas associações desses quatro materiais no ambiente bucal de um paciente são passíveis de gerar par galvânico, convertendo o material menos nobre em metal de sacrifício e facilitando sua corrosão, o que reforça o cuidado que um profissional da área odontológica deve ter no uso adequado desses materiais metálicos.

14) Para o caso específico da liga Ni-Cr-Mo-Ti, as grandes heterogeneidades, já apontadas pelos ensaios em MEV-EDS, sugerem a possibilidade de formação de pares galvânicos inclusive entre as diferentes fases do material, dependendo dos potenciais de corrosão médios que a composição de cada fase apresenta. 
15) Ainda a respeito dessa liga, os resultados de FAAS, destacados na tabela 2 da página 30, mostraram que as amostras obtidas continham menor teor de Ti e de $\mathrm{Cr}$ que o especificado pelo fabricante, além de quantidade apreciável de Al, elemento não presente nas especificações do material.

16) Essa composição fora do previsto, e talvez a própria heterogeneidade apresentada pela liga, podem ser os fatores responsáveis pela relação encontrada entre os potenciais de polarização aplicados e as densidades de corrente obtidas, desde o início das polarizações; tais valores não parecem pertencer a um material de filme passivo com a resistência esperada para essa liga, que foi introduzida no mercado para substituir a liga áurica, reconhecidamente inerte. Esse problema é grave e deve ser melhor estudado.

\subsection{Sugestões para Trabalhos Futuros}

Os estudos por espectroscopia por impedância eletroquímica (EIE), realizados apenas para quatro dos sistemas estudados, devem ter continuidade para os demais sistemas.

Os resultados obtidos por EIE e analisados qualitativamente neste trabalho podem ser ampliados, empregando-se circuitos equivalentes para uma melhor interpretação cinética.

A adsorção da albumina deve ser melhor estudada, principalmente nos casos em que se admite complexação. O levantamento de isotermas de adsorção, aliado a estudos não-eletroquímicos in situ, por técnicas de espectroscopia, deve ser recomendado. 
Referências Bibliográficas

[1] R.W. Phillips; Materiais Dentários de Skinner; Editora Guanabara Koogan, Rio de Janeiro, 1986.

[2] R. Adell, U. Lekholm, B. Rockler, Branemark; A 15 Years study of osseointegrated implants in the treatment of the edentulous jaw; Int J Oral Surg (1981), 10: 387-416.

[3] H.A. Acciari, E.N. Codaro, A.C. Guastaldi; A comparative study of the corrosion of high copper dental amalgams, Materials Letters 1998 36: $148-151$.

[4] M.H. Fathi, M. Salehi, A. Saatchi, V. Mortazavi and S.B. Moosavi; In vitro corrosion behavior of bioceramic, metallic, and bioceramic-metallic coated stainless steel dental implants, Dental Materials, Volume 19, Issue 3, May 2003, Pages 188-198.

[5] F. Toumelin-Chemla, F. Rouelle and G. Burdairon; Corrosive properties of fluoride-containing odontologic gels against titanium, Journal of Dentistry, Volume 24, Issues 1-2, 3 January 1996, Pages 109-115.

[6] S. Omanovic and S.G. Roscoe; Electrochemical studies of the adsorption behavior of bovine serum albumin on stainless steel; Langmuir 1999; 15: $8315-8321$.

[7] M.L.C. Afonso, R.F.V. Villamil, E.P.G. Arêas, S.M.L. Agostinho; Efeito da albumina sobre o comportamento eletroquímico de aços inoxidáveis em meio de NaCl 0,11 M; XV Congresso da Sociedade Ibero-Americana de Electroquímica (SIBRAE 2002); 8-13 Setembro de 2002, Évora - Portugal.

[8] J.C. Wataha, S.K. Nelson and P.E. Lockwood; Elemental release from dental casting alloys into biological media with and without protein, Dental Materials, Volume 17, Issue 5, September 2001, Pages 409-414. 
[9] S. Omanovic and S.G. Roscoe; Interfacial behaviour of $\beta$ - lactoglobulin at a stainless steel surface: an electrochemical impedance spectroscopy study; Journal of Colloid and Interface Science 2000; 227: 452-460.

[10] K. Merrit and S. Brown; Effect of proteins and pH on fretting corrosion and metal ion release; Journal of Biomedical Materials Research 1988; 22: $111-120$.

[11] H. Huang; Effect of fluoride and albumin concentration on the corrosion behavior of Ti-6AI-4V alloy; Biomaterials 2003; 24: 275-282.

[12] M.L.C. Afonso, R.F.V. Villamil, E.P.G. Arêas, S.M.L. Agostinho; Efeito da concentração de níquel (no metal) e da albumina (em solução) no comportamento eletroquímico de aços inoxidáves; $7^{a}$ Conferência sobre Tecnologia de Equipamentos (COTEQ236_03); 9-12 Setembro 2003, Florianópolis, Santa Catarina - Brasil.

[13] G.A. Jesuíno, L.M.F. Ribeiro, R.Z. Nakazato et alii. Propriedades mecânicas e resistência à corrosão da liga Ti-4AI-4V obtida da reciclagem da liga Ti-6AI-4V. Mat. Res., 2001, vol.4, no. 2, p. 63-69. ISSN 1516-1439.

[14] Y. Fovet, J.Y. Gal and F. Toumelin-Chemla; Influence of pH and fluoride concentration on titanium passivating layer: stability of titanium dioxide, Talanta, Volume 53, Issue 5, 26 January 2001, Pages 1053-1063.

[15] G. Challa; Polymer Chemistry, An Introduction; Ellis Horwood Ltd.; Great Britain; p. 59-61 (1993).

[16] A. MacInally; The Properties and Applications of a New Epoxy Vinyl Éster Resin for Corrosion Resistant Applications, Dow Deutschland Inc.; D-77836 Rheinmuenster Germany.

[17] Instrução Normativa no. 36, de 14 de outubro de 1999, do Ministério da Agricultura e do Abastecimento.

[18] D.C. Carter, J.X.E. Ho; Advances in Protein Chemistry; Academic Press: Huntsville/Alabama, 1994, v. 45. 
[19] T.L. Brown, H.E. LeMay Jr., B.E. Bursten; Chemistry: The Central Science; Prentice Hall; New Jersey; $17^{\text {th }}$ edition; p. 280 (1997).

[20] D.C. Harris; Análise Química Quantitativa; 5a. ed.; LTC Editora (2001); p. $799-800$.

[21] D. Jackson, Omanovic and Roscoe ; Electrochemical studies of the adsorption behavior of serum proteins on titanium; Langmuir, v. 16, 2000, p. $5449-57$

[22] C.A.L. Santos; Contribuições ao Processo de Eletrodeposição do Gálio sobre Cobre e Estudo das Interfases $\mathrm{Cu} / \mathrm{NaOH}$ e $\mathrm{Pt} / \mathrm{NaOH}$ na Ausência e Presença de Íons Acrilato; tese de doutorado; IQ-USP; 2003. 


\section{CURRICULUM VITAE}

NOME NASCIMENTO
Jocicler Claudio Vieira

São Paulo Capital, 13 de outubro de 1969

\section{FORMAÇÃO ACADÊMICA}

- Licenciatura Plena com Habilitação em Química, Física e Matemática, pela Universidade Mackenzie (1994).

- Bacharelado em Química com Atribuições Tecnológicas, pela Universidade Mackenzie (1994).

- Técnico em Química, pela Escola Técnica Federal de Sergipe (1987).

\section{COMUNICAÇÕES EM CONGRESSOS / PUBLICAÇÕES}

1. Carlos V.G. Araújo, Eduardo Inada, Jocicler C. Vieira, Ruth F.V. Villamil, Pedro Tortamano Neto, Silvia M.L. Agostinho; Caracterização Eletroquímica da liga Ni-Cr-Mo-Ti em meio de $\mathrm{NaCl} \mathbf{0 , 1 5} \mathrm{mol} \mathrm{L}^{-1}$; trabalho apresentado, na forma oral, no I Congresso Brasileiro de Biomateriais em Odontologia (Biodonto 2004, Natal$R N$ ) e reapresentado, na forma de painel, na $21^{a}$ Semana da Química do IQ-USP; 2004. Publicado como trabalho completo nos anais do referido congresso, em CD-ROM.

2. Eduardo Inada, Carlos V.G. Araújo, Jocicler C. Vieira, Ruth F.V. Villamil, Silvia M.L. Agostinho, Pedro Tortamano Neto; Viabilidade do emprego da Liga Ni-Cr-Mo-Ti nas Próteses sobre Implantes Osseointegrados, painel apresentado na XII Reunião de Pesquisa da Faculdade de Odontologia da USP; 2004. Publicado, na forma de resumo, nos anais da referida reunião.

3. Jocicler C. Vieira; Silvia M.L. Agostinho; Avaliação do Desempenho de Diferentes Polímeros Empregados na Construção de Eletrodos Sólidos; trabalho apresentado, como painel, no XLV Congresso Brasileiro de Química (CBQ 2005, Belém-PA), promovido pela Associação Brasileira de Química; 2005. Publicado, na forma de resumo, nos anais do referido congresso.

\section{HISTÓRICO PROFISSIONAL: ENSINO MÉDIO DE QUÍMICA}

2005 até o momento 1999 até o momento 2004 a 2004

2003 a 2004

2002 a 2003

2003 a 2003

2002 a 2002

2002 a 2002

2001 a 2002

2000 a 2001

1999 a 2000

1996 a 1997

1995 a 1999

1995 a 1995

1992 a 1994
Curso e Colégio Universitário, Taboão da Serra-SP Professor de Química Anglo Vestibulares, São Paulo-SP Curso e Colégio Lumens, Santos-SP Curso Pró-USP, São Paulo-SP Curso Psico-USP, São Paulo-SP MED Vestibulares, São Paulo-SP Curso e Colégio COC, São Paulo-SP Curso Medicina, São Paulo-SP Cursinho da UMES, São Paulo-SP Alferes Vestibulares, São Paulo-SP Curso e Colégio Desafio, São Paulo-SP Colégio São Vicente de Paulo, São Paulo-SP Curso e Colégio Etapa, São Paulo-SP Colégio Alvorada, São Paulo-SP Rede Pública de Ensino, São Paulo-SP
Professor/Plantonista de Química Professor de Química Professor de Química Professor de Química Professor de Química Professor de Química Professor de Química Professor de Química Professor de Química Professor de Química Professor de Química Plantonista de Química Professor de Química Professor de Química

\section{HISTÓRICO PROFISSIONAL: ÁREA TÉCNICA DE QUÍMICA}

1994 a 1994

1993 a 1993

1990 a 1992

1988 a 1989

1988 a 1988
Philips do Brasil Ltda. - Walita, São Paulo-SP Axios Elastômeros Ltda., São Paulo-SP Ipiranga Comercial Química S.A., São Paulo-SP Inmont Ind. Quím. Ltda. - Basf, São Paulo-SP Crown Cork do Brasil S.A., São Paulo-SP
Estagiário Nível Superior Estagiário Nível Superior Técnico Químico Técnico Químico Estagiário Nível Médio 